\title{
Evaluation of Time-Dependent \\ Pile Capacity Increase in Soft Clay
}

\author{
by
}

\section{Alireza Afshin}

A thesis submitted to the Faculty of Graduate and Postdoctoral Affairs in partial fulfillment of the requirements for the degree of

\section{Master of Applied Science}

in

Civil Engineering

\author{
Carleton University \\ Ottawa, Ontario
}

(C) 2012

Alireza Afshin 
Library and Archives

Canada

Published Heritage

Branch

395 Wellington Street

Ottawa ON K1A ON4

Canada
Bibliothèque et

Archives Canada

Direction du

Patrimoine de l'édition

395 , rue Wellington

Ottawa ON K1A ON4

Canada
Your file Votre référence

ISBN: 978-0-494-93492-0

Our file Notre référence

ISBN: 978-0-494-93492-0
NOTICE:

The author has granted a nonexclusive license allowing Library and Archives Canada to reproduce, publish, archive, preserve, conserve, communicate to the public by telecommunication or on the Internet, loan, distrbute and sell theses worldwide, for commercial or noncommercial purposes, in microform, paper, electronic and/or any other formats.

The author retains copyright ownership and moral rights in this thesis. Neither the thesis nor substantial extracts from it may be printed or otherwise reproduced without the author's permission.
AVIS:

L'auteur a accordé une licence non exclusive permettant à la Bibliothèque et Archives Canada de reproduire, publier, archiver, sauvegarder, conserver, transmettre au public par télécommunication ou par l'Internet, prêter, distribuer et vendre des thèses partout dans le monde, à des fins commerciales ou autres, sur support microforme, papier, électronique et/ou autres formats.

L'auteur conserve la propriété du droit d'auteur et des droits moraux qui protege cette thèse. $\mathrm{Ni}$ la thèse ni des extraits substantiels de celle-ci ne doivent être imprimés ou autrement reproduits sans son autorisation.
In compliance with the Canadian Privacy Act some supporting forms may have been removed from this thesis.

While these forms may be included in the document page count, their removal does not represent any loss of content from the thesis.
Conformément à la loi canadienne sur la protection de la vie privée, quelques formulaires secondaires ont été enlevés de cette thèse.

Bien que ces formulaires aient inclus dans la pagination, il n'y aura aucun contenu manquant. 


\begin{abstract}
An extensive experimental program was developed to study the evolution of pile capacity increase with time for driven piles into soft clay. First phase of the experiment was developed to investigate the pile-soil interface shear strength behaviour over time, employing a modified direct shear test apparatus, for both steel and concrete piles. The interface strength obtained for pile-soil specimens was found to be less than those of soilsoil tests. Residual friction angle for steel-soil interface was lower than that of the concrete-pile tests. The interface shear strength for both concrete-soil and steel-soil system increased as the consolidation time increased.

A series of pile load testing was also performed on piles driven into soft clay using medium scaled model tests in laboratory. A variety of different piles were driven into the undisturbed Leda clay samples and their capacity was measured immediately after driving and repeated at appointed elapsed time stages. Results showed a minimum $60 \%$ of pile capacity increase, twelve days after initial pile driving. The large portion of this setup was generated within the first day due to the fast excess pore water pressure dissipation, and afterward, the pile capacity was increased at a very lower rate. The pile setup rate was shown to be higher for concrete pile in comparison with steel piles, possibly due to higher moisture absorbance. The research also revealed that pile setup rate for displacement piles are slightly higher than that of non-displacement piles.
\end{abstract}


Dedicated to My wife

And our immediate family 


\section{ACKNOWLEDGEMENT}

First and foremost, I would like to express my appreciation to my advisor, Dr. Mohammad T. Rayhani for his guidance, support and patience, which made my graduate study and this research possible.

My utmost gratitude is extended to my revered dissertation committee, Dr. Siva Sivathayalan, Dr. Mamadou Fall for their efforts in reviewing this thesis and providing valuable comments. I am truly honoured that they are associated with this research.

The support and patience of my employer, AATech Scientific Inc. (ASI) is greatly appreciated. In particular, I would like to thank Mr. Fred Agharazi and Mr. H. (Sam) Salem who created this opportunity for me to pursue my career goals.

This research has been founded by ASI and Natural Sciences and Engineering Research Council of Canada (NSERC). These supports are gratefully acknowledged.

More thanks go to my friend, graduate student, Juan Giraldo for his valuable help and effort, and also to all my classmates who's support and feedback I will never forget.

I would like my family to know how much I appreciate them for their support and persuasion, and for encouraging me to continue my studies. This thesis is dedicated to them, with love. And finally, I wish to extend to my lovely wife, and love of my life, Mrs. Paria Kashani, more thanks and appreciation than words can convey. This would not have happened without her support and encouragement. Paria, 1 love you, and this is for you. 


\section{TABLE OF CONTENTS}

TITLE PAGE

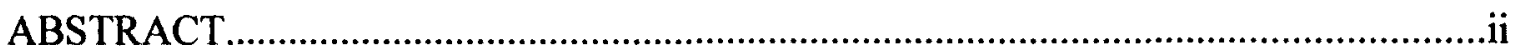

ACKNOWLEDGEMENT................................................................................................

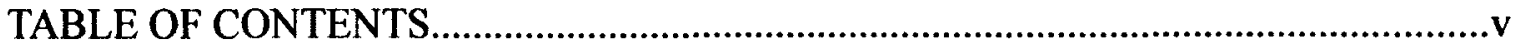

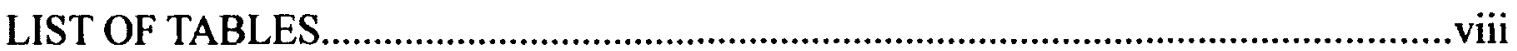

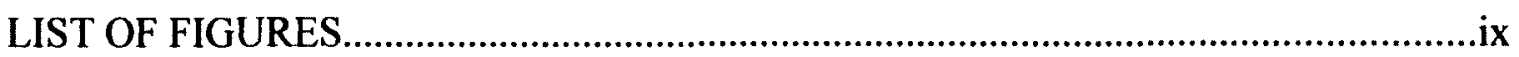

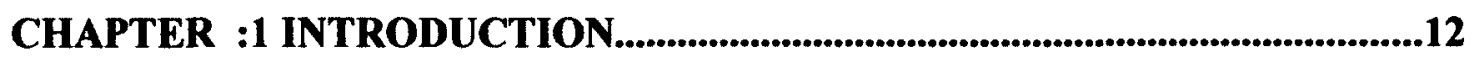

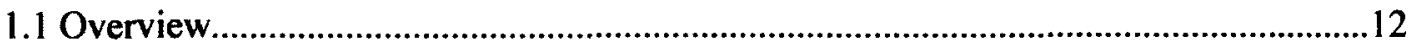

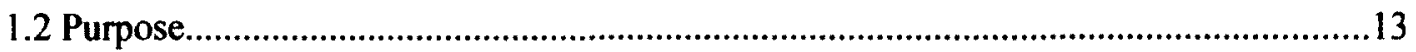

1.3 Organization of thesis................................................................................................14

CHAPTER :2 LITERATURE REVIEW...............................................................15

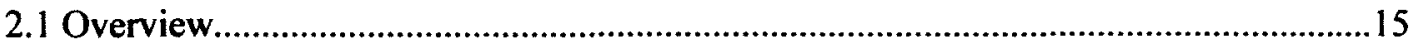

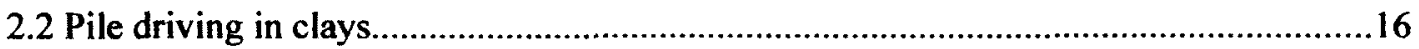

2.2.1 Soil disturbance and remolding........................................................................

2.2.2 Pore Water Pressure (PWP) change ……………………..................................17

2.2.3 Pore water pressure dissipation and stress stabilization..........................................18

2.3 Pile setup

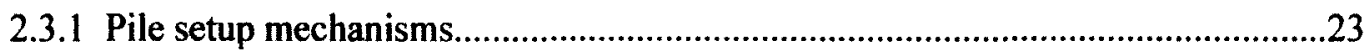

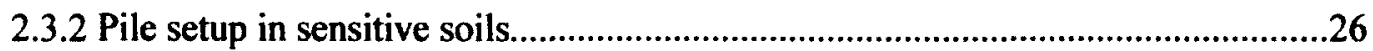

2.3.3 Effect of pile-soil interface parameters on setup...................................................27

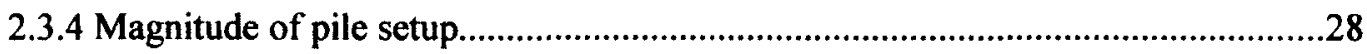

2.3.5 Pile setup in group piles...................................................................................

2.3.6 Pile setup in displacement versus non-displacement piles.......................................33

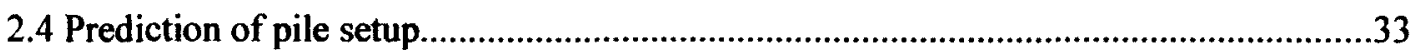

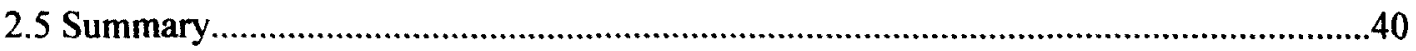

CHAPTER :3 EVALUATION OF PILE SETUP IN WINNIPEG CLAY.............42

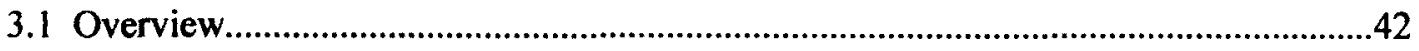

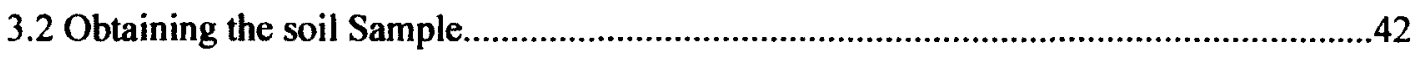

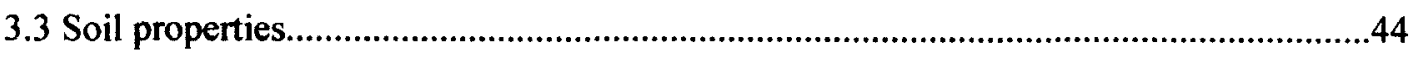

3.4 Experimental procedure 


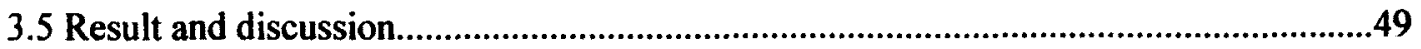

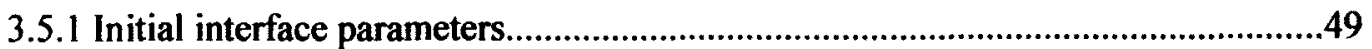

3.5.2 Evolution of pile soil interface strength with time...........................................53

3.5.3 Effect of pile materials on time dependent interface strength..............................59

3.5.4 Comparison with results of pile load test in the field..........................................60

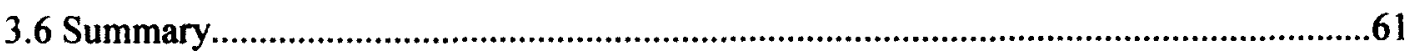

CHAPTER :4 PILE SETUP EVALUATION IN LEDA CLAY, OTTAWA, ON...63

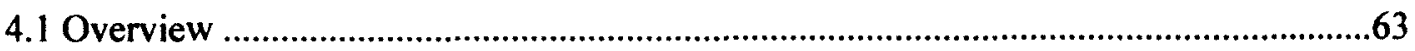

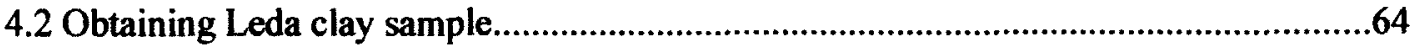

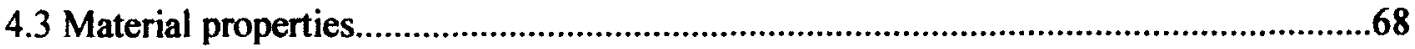

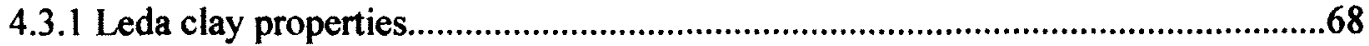

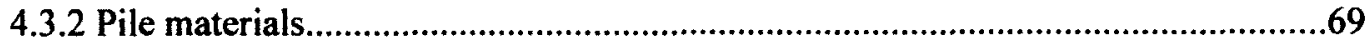

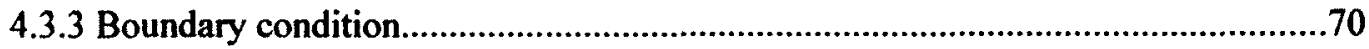

4.4 Experimental Program...................................................................................................73

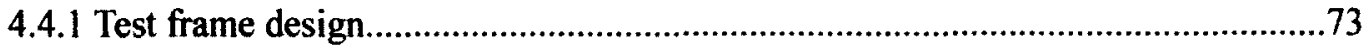

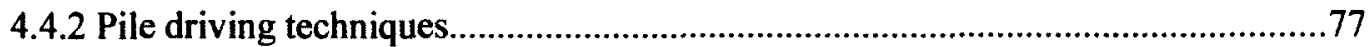

4.4.3 Pore water pressure monitoring...........................................................................

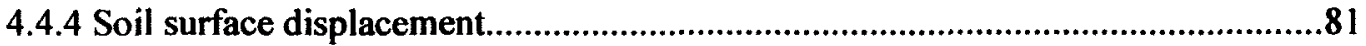

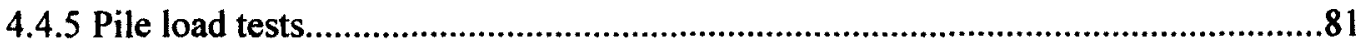

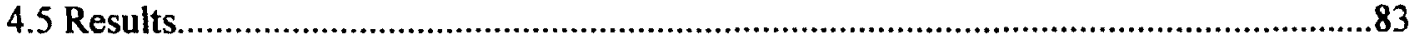

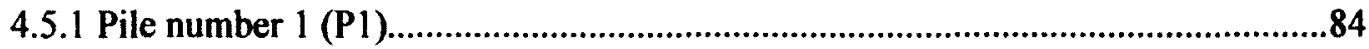

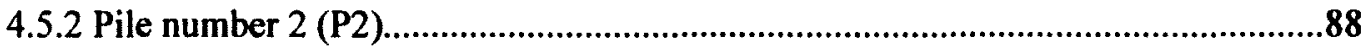

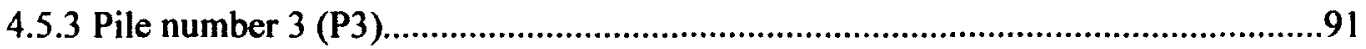

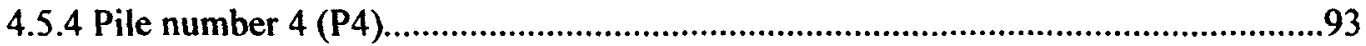

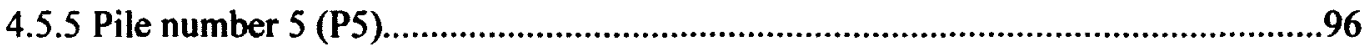

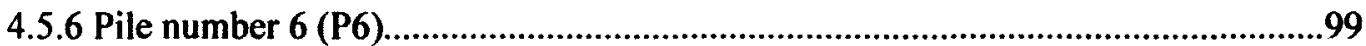

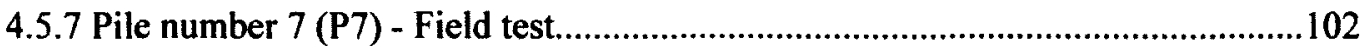

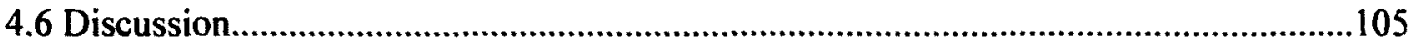

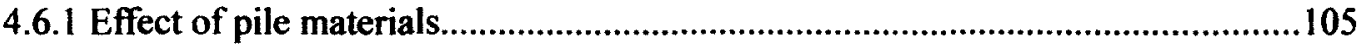

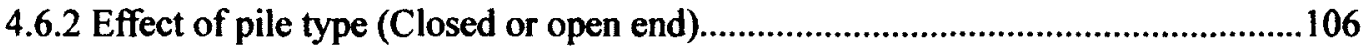

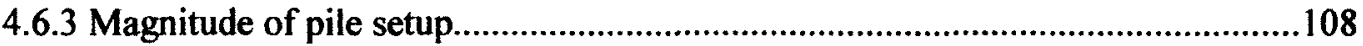

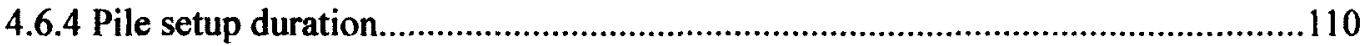

4.6.5 Comparison with field test result......................................................................111 
4.6.6 Comparison with previous studies.................................................................113

4.6.7 Comparison the measured pile capacity with static analysis (a-Method)..............114

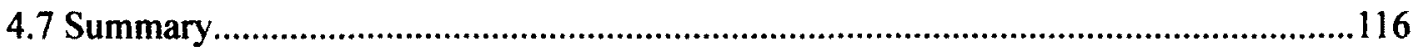

CHAPTER :5 CONCLUSIONS AND RECOMMENDATION..........................117

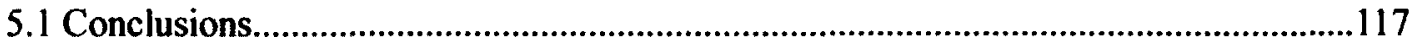

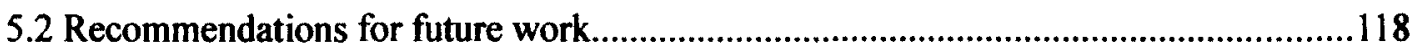

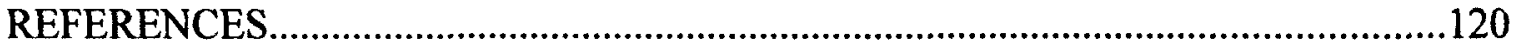

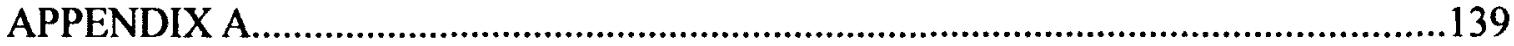

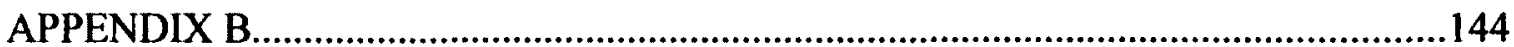




\section{LIST OF TABLES}

Table 2.1: Various value for $\mathrm{A}$ and t0 parameters ( Skov and Denver, 1988) ....................37

Table 2.2: Additional equations for setup prediction...........................................................38

Table 3.1: Index properties of soil samples, South-Winnipeg, MB....................................44

Table 3.2: Details of soil and interface shear tests..............................................................48

Table 4.1: Index properties of soil samples, Leda clay, Navan, ON.................................68

Table 4.2: Pile load test types and setup rate Summary.....................................................84

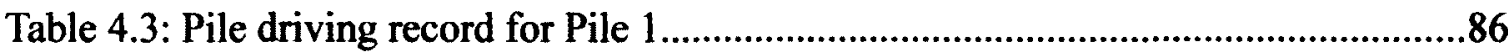

Table 4.4: Pile driving record for Pile 2 ...........................................................................89

Table 4.5: Pile driving record for Pile 3.......................................................................92

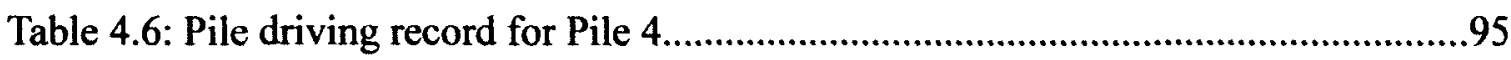

Table 4.7: Pile driving record for Pile 5..........................................................................97

Table 4.8: Pile driving record for Pile 6......................................................................100

Table 4.9: Pile driving record for Pile 6......................................................................103 


\section{LIST OF FIGURES}

Figure 2.1: Rate of pore water pressure dissipation with time around a driven pile ........20 Figure 2.2: Variation of pore water pressure along the shaft of a cone (Tummay et al., 1982).

Figure 2.3: Pile bearing capacity increase with time for pile driven into clay..................22

Figure 2.4: Pile capacity decrease with time after initial drive into the clay......................22

Figure 2.5: Idealized illustration of pile setup phases (Komurka et al., 2003)..................24

Figure 2.6: Pore water pressure generation around a single and group of piles.................32

Figure 2.7: Example of pile capacity increase with time (Cgt: setup parameter).............35

Figure 2.8: Comparison of measured pile setup with theoretical setup capacity for (a) Driven pile into Draummen clay, (b) Driven pile into San Francisco Bay mud (after Randolph et al., 1979)................................................................................................38

Figure 3.1: Clay sample location, south of Winnipeg, MB..............................................43

Figure 3.2: Grain size distribution of South-Winnipeg Clay...............................................45

Figure 3.3: Schematic view of the direct shear apparatus for interface tests......................47

Figure 3.4: Surface Roughness for concrete and steel, using FARO arm

Figure 3.5: Shear stress-displacement curves for soil-soil and soil-pile shear tests; a) soilsoil, b) steel-soil, and c) concrete-soil............................................................................52

Figure 3.6: Stress envelope for soil-soil and soil-pile shear tests.....................................53

Figure 3.7: Increase in interface strength of steel-soil system...........................................55

Figure 3.8: Increase in interface strength of concrete-soil system.....................................56

Figure 3.9: Comparison of measured increase in interface strength of concrete-soil with

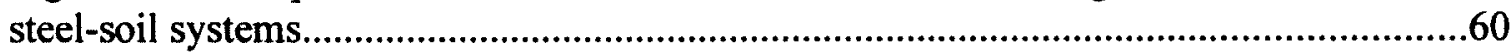

Figure 4.1: Extent of Leda clay in Ottawa and St. Lawrence River lowlands...................64

Figure 4.2: Holes provided at the bottom of the barrel as air vent.....................................65

Figure 4.3: Barrels are placed upside down on the undisturbed Leda clay........................66

Figure 4.4: Barrels are pushed into the clay, very slowly..................................................66

Figure 4.5: Barrels are buried into the clay....................................................................67

Figure 4.6: Barrels are extracted, cleaned and sealed.......................................................67

Figure 4.7: Grain size distribution of Leda Clay, Navan, ON...........................................69

Figure 4.8: 48mm diameter precast concrete pile and steel pipe pile................................70

Figure 4.9: Numerical analysis model of driven pile in Leda clay barrel, ........................72 
Figure 4.10: Static load test frame illustration.................................................................74

Figure 4.11: Load test frame........................................................................................75

Figure 4.12: Vertical support mechanism: Two pieces of plywood restrain pile from lateral movement...........................................................................................................

Figure 4.13: Pile cap plate, load transfer rod and digital indicator.....................................77

Figure 4.14: Pile driving setup.......................................................................................78

Figure 4.15: Steel pipe pile marked each $50 \mathrm{~mm}$ for driving............................................79

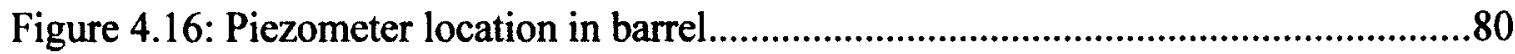

Figure 4.17: Static pile loading setup in tension (a) and compression (b) positions.........82

Figure 4.18: PDA sensors installed on a steel pile (left) ......................................................83

Figure 4.19: Pile capacity versus displacement for Pile 1 ...................................................86

Figure 4.20: Pore water pressure versus log-time for Pile 1............................................87

Figure 4.21: Pile capacity versus time for Pile 1 ...............................................................87

Figure 4.22: Pile capacity versus displacement for Pile 2....................................................90

Figure 4.23: Rate of pile setup versus time for Pile 2 …....................................................90

Figure 4.24: Pile capacity versus displacement for Pile 3..................................................92

Figure 4.25: Rate of pile setup versus time for Pile 3 ………….........................................93

Figure 4.26: Pile capacity versus displacement for Pile 4..................................................95

Figure 4.27: Pore water pressure versus log-time for Pile 4.............................................96

Figure 4.28: Pile capacity versus displacement for Pile 5...................................................98

Figure 4.29: Pore water pressure versus log-time for Pile 5.............................................98

Figure 4.30: Rate of pile setup versus time for Pile 5........................................................99

Figure 4.31: Pile capacity versus displacement for Pile 6...............................................101

Figure 4.32: Rate of pile setup versus time for Pile 6......................................................101

Figure 4.33: Field pile load test setup, Geotechnical Test Site, Gloucester, ON ............103

Figure 4.34: Pile capacity versus displacement for Pile 7, Field test................................104

Figure 4.35: Rate of pile setup versus time for Pile 7......................................................104

Figure 4.36: Setup rate comparison between driven concrete and steel pile....................106

Figure 4.37: Penetration resistance comparison,..............................................................107

Figure 4.38: Setup rate comparison between displacement and non-displacement piles 108 Figure 4.39: Pile setup data for all the experiments tested...............................................109

Figure 4.40: Pile setup comparison between field test and laboratory test ...................112 
Figure 4.41: Pile bearing capacity increase with time for piles driven into clay. Date from experiment has been illustrated as dash-line. (modified from Titi, 1996)........................115

Figure 4.42: Pile capacity comparison, measured and calculated.....................................115 


\section{CHAPTER :1 INTRODUCTION}

\subsection{Overview}

Determination of ultimate pile capacity is important for proper design and construction of pile foundations. Pile capacity is normally estimated by static bearing capacity formulas and then confirmed by pile load tests. Most of the time, the pile load test is carried out shortly after the installation of pile. The pile capacity obtained from the load test is often assumed to be the ultimate pile capacity in most of design methods. However, during pile installation, the soil around the pile experiences large deformations and changes in excess pore water pressure, which in turn reduces the shear strength and pile bearing capacity. After the completion of pile driving, the pile capacity increases as the strength of the surrounding soil increases mainly by reconsolidation, manifested by the dissipation of excess pore pressure at the soil-pile interface zone (Fioravante, 2002; Lehane and White , 2005). This time dependent increase in bearing capacity of driven piles is referred as "pile setup" or "Freeze" in pile industry. The amount of increase in pile capacity and the time required for complete dissipation of excess pore water pressure depend on soil properties, pile characteristics and other parameters such as rate of loading and pile-soil interface properties.

The phenomenon of time dependent pile capacity gain in cohesive soils has been documented by many researchers (e.g., Seed and Reese 1955, Tomlinson 1971, Randolph 
et al. 1979, Thorburn and Rigden 1980, Skov and Denver 1988, Fellenius et al. 1989, Svinkin et al. 2000, Komurka et al., 2003). However, the increase in pile capacity is not incorporated in current pile design procedures, due to lack of full understanding of the gain mechanisms and how several factors such as soil type, pile material and its installation method affect capacity gain. Most research have been done in a specific location and logically the result would be incorporate for the same investigated soil or area and, moreover, the amount of studies on the very unique cohesive soil in Canada is very few. Therefore, the ultimate pile capacity could be underestimated if pile load test was carried out while excess pore water pressure still remains, which may lead to a conservative pile design. Accurate estimation of pile setup, rather than measuring directly in the field, may reduce the cost of piling and still provide the required performance for the pile.

\subsection{Purpose}

The purpose of this research is to conduct experimental research aimed at developing an understanding of the strength gain at the interface of pile and soil in soft clays in Canada and to develop relationship between the pile capacity and elapsed time after the end of initial driving for cohesive soils. The proposed research will involve a series of controlled laboratory tests that will examine the effect of soil type, pile material, and its installation method on capacity gain. Prediction of pile capacity gain with time after driving would certainly be advantageous from an economic standpoint. Incorporating the effects of setup into pile design is expected to reduce the general cost of piling project by reducing 
pile diameter, pile length, size of driving equipment, and subsequently piling duration. This study will complement the work of other researchers in this field by providing unique experimental data necessary for the evaluation of current design approach pertaining to pile design in cohesive soils mostly in Manitoba and Eastern Canada.

\subsection{Organization of thesis}

This thesis consists of 5 chapters. Chapter 1 briefly introduces the pile setup and importance of considering it in pile foundation design. It also presents the objective of the research as well as the format of this thesis. Chapter 2 includes background knowledge on behaviour of driven piles into the clay and transition of pile capacity with time and also effective factors on pile capacity. Chapter 3 presents an experimental testing which studies the pile setup in soft clay obtained from south of Winnipeg, MB using modified direct shear tests. This experiment tends to examine the evolution of pile-soil interface strength with elapsed time. Chapter 4 expresses information regarding a medium scale pile load testing on driven piles into Leda clay, obtained from Ottawa, ON. The experiment tends to study the rate of scaled-pile capacity increase with time. Results from the pile load tests conducted on medium scale experiments in lab were compared and verified with those performed in the field using similar configurations. Chapter 5 summarizes the outcome of this research and provides recommendations for future research. 


\section{CHAPTER :2 LITERATURE REVIEW}

\subsection{Overview}

Deep foundation or pile foundation system is used where soil condition at shallow depth is not adequate or in case of any physical constraints to spread a shallow foundation. Relative to the shallow foundation, piles are slender structures and transmit the applied loads to the deeper soil layer. Depending on their function, piles are categorized in two major types Toe (end) Bearing Piles, when piles rest on a suitable bearing layer in deep soil layer, and Friction Piles, when pile resistance is provided by friction resistance between pile shaft and adjacent surrounding soil. Furthermore, piles are classified according to their displacement properties in three classifications of Full-displacement, Partial-displacement and Non-displacement piles.

Pile capacity is affected by many different parameters including pile type, pile installation method and soil properties, type of load application and also pile behaviour during its lifetime. It would be beneficial to study pile behaviour when it is being driven, while pile is at rest before load application and also after load application. In this literature review, behaviour of piles driven into the soft and sensitive clay and their timedependent behaviour are reviewed and presented. 


\subsection{Pile driving in clays}

Deformation and disturbance in the surrounding soil of the pile and excess pore water pressure generation is caused due to pile penetration in any clay-water system (Poulos and Davis, 1980; Baligh and Levadoux, 1980). These changes in the soil system may affect the pile behaviour at any stage of its lifetime. De Mello (1969) described effects of pile driving in saturated clay in four stages:

- Disturbance and remolding of adjacent surrounding soil, while pile driving

- Excess pore water pressure generation and change in stress state of the soil

- Dissipation of generated excess pore water pressure

- Increasing soil strength with time

\subsubsection{Soil disturbance and remolding}

Driving pile into soil will cause soil displacement equal to pile's volume. However, the amount of displacement could be different depending on the pile type, in terms of open or closed toe. Soil displacement may cause soil heave at the beginning of the driving procedure in the shallow depth. Effective disturbance depth could be up to five times of the pile diameter (Cooke and Price, 1973). The displacement and disturbance of the soil around the driven pile has also shown to decrease undrained shear strength of the surrounding soil and this reduction is observed in a zone located between the pile surface and twice of its diameter (Housel and Burkey, 1948; Cummings et al., 1950; Seed and Reese, 1955; Orrje and Broms, 1967; Flaate, 1972; Fellenius and Simson, 1976 and 
Bozozuk et al., 1978). Soil strength reduction is caused by reconstruction of soil particles around the pile while this reconstruction provides more space which is filled with water (Terzaghi, 1941). Reduction in water content of soil surrounding the pile in the zone of $150 \mathrm{~mm}$ away from pile shaft was also proposed by some researchers (e.g., Seed and Reese, 1955; Flaate, 1968).

\subsubsection{Pore Water Pressure (PWP) change}

Pile driving in clay-water system is considered as undrained condition due to a relatively quick process of soil remolding compared to excess pore water pressure dissipation. According to effective stress principal, pore water pressure is calculated as effective stress subtracted from total stress. While pile is advanced into the soil, total mean stress is increased as the pile forces the soil away, and based on soil behaviour, effective stress might decrease or increase. If soil has tendency to dilate, effective stress is increased and if the soil tends to shrink upon shearing, effective stress will decrease. In case of dealing with normally consolidated or slightly over consolidated clay, soil will shrink as clay tends to compress. As mentioned before, undrained shearing will cause an increase in the pore water pressure.

This generated excess pore water pressure was observed by Bjerrum et al. (1958), Lo and Stermec (1965), Lambe and Horn (1965), Koizumi and Ito (1967), Orrje and Broms (1967), Flaate (1968), D'Appolonia and Lambe (1971), Clark and Meyerhof (1972, 1973), Bozozuk et al. (1978), Sutton and Rigden (1979), Konard and Roy (1987), Chung (1988), Bogard and Matlock (1990), Leung et al. (1991) and many other 
researchers. They agree that generated excess pore water pressure reaches its maximum in vicinity of the pile surface (shaft area) and decreases as it gets farther from the pile, up to ten times of the pile diameter. The amount of pore water pressure could be as high as initial effective overburden pressure at certain depth. The increase in pore water pressure can exceed the existing overburden pressure within one-diameter of the pile (Pestana et al., 2002; Randolph, et al., 1979).

Prediction of excess pore water pressure magnitude upon pile driving has been of interest to many investigators. Several researchers presented theoretical approaches to predict the excess pore water pressure within the soil. Nishida (1964) proposed a prediction using elasto-plasticity analysis, while Ladanyi (1963) suggested a solution based on expansion of a cylindrical cavity. Also, Lo and Stermac (1965) as well as D' Appolonia and Lambe (1971) introduced a theoretical solution based on mean total stress increase in normally and slightly consolidated clays. Randolph et al. (1979) presented an equation which was developed based on the relation between excess pore water pressure and change in mean effective stress as a result of shearing, disturbing and changes in undrained soil shear strength.

\subsubsection{Pore water pressure dissipation and stress stabilization}

Stabilization of pore water pressure begins immediately after change in pore water pressure takes place due to soil remolding. Basically, excess pore water pressure dissipates on the same path as it is generated on. In fact, dissipation starts from vicinity of the pile shaft and moves towards the surrounding soil in a radial path. As the excess pore 
water pressures dissipate, the effective stress of the affected soil increases, and the pile capacity increases as a result of increased shear strength and lateral stress against the pile. The shear strength of the reconsolidated soil has been reported to be higher than the soil's undisturbed shear strength (Randolph et al., 1979). As the distances from the pile increases, soil strength decreases, until it reaches the soil's initial strength at approximately 10-Pile radius (Randolph et al., 1979). Flaate (1972) reported a significant increase in shear strength of the soil after reconsolidation at the Nitsund bridge site. Also, Orrje and Broms (1967) reported increase in shear strength of the surrounding soil of the pile, nine months after initial driving. Seed and Reese (1955) reported a relation between the increase in shear strength and reduction in water content of the soil.

Figure 2.1 presents pore water dissipation for a pile driven into Boston blue clay (Paikowski et al., 1995). Tumay et al. (1982) reported that any change in pore water pressure is dependent on the stress around the shaft and varies along the pile length. The generated excess pore water pressure reaches its maximum at pile tip (Figure 2.2).

\subsection{Pile setup}

Pile "Setup" or "Freeze" is basically associated with an increase in soil resistance acting on the pile perimeter surface (Axelsson, 2002; Bullock, 1999; Chow et al., 1998). Although the majority of the setup is likely attributed to dissipation of excess pore water pressures and subsequent consolidation of the disturbed soil surrounding the pile, the complete mechanisms contributing to setup are not well understood. 


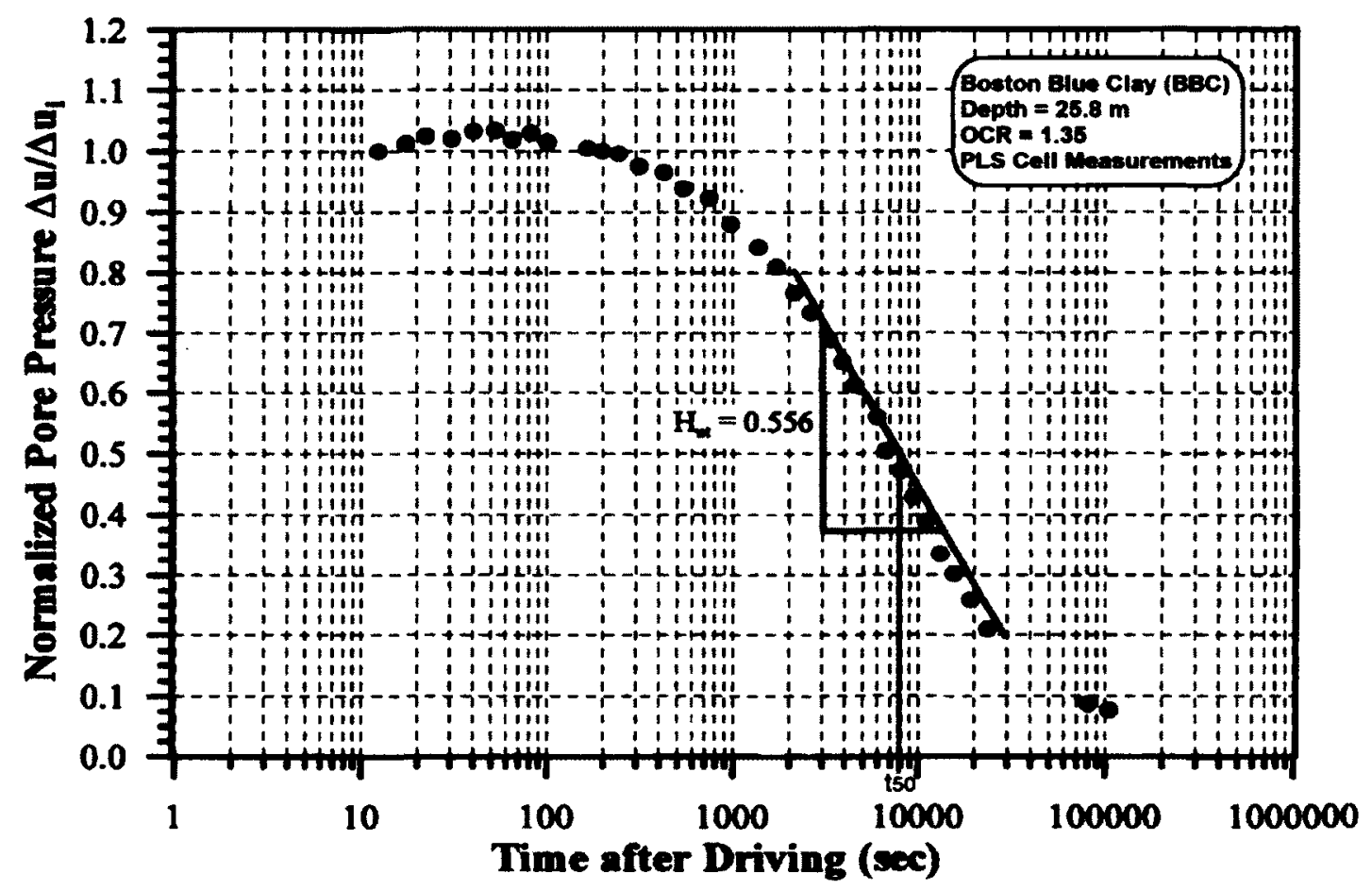

Figure 2.1: Rate of pore water pressure dissipation with time around a driven pile (Paikowski et al., 1995), H.t: Horizontal pore water pressure dissipation

The phenomenon of time dependant increase of pile capacity has been documented by considerably large number of researchers including Yang (1965), Seed and Reese (1955), Housel (1948), Eide et al. (1961), McClelland (1969), McCammon and Golder (1970), Flaate (1972), Thorburn and Rigdan (1980), McManis et al. (1988), Chung (1988), Skov and Denver (1988), Fellenius et al. (1989), Coop and Wroth (1989) and Bogard and Matlock (1990). All studies mentioned above agreed on an increase of pile skin friction with time and hence increase in pile bearing capacity (Figure 2.3).

However, decrease in pile capacity with time after pile driving has also been reported by a few researchers (e.g., Kraft et al., 1981; Fellenius et al., 1989; Bond and 
Jardine, 1991) (Figure 2.4). This decrease in capacity, termed relaxation, is more likely to affect toe resistance than shaft resistance. This literature review tends to run over previous studies regarding friction pile capacity and its increase with time.

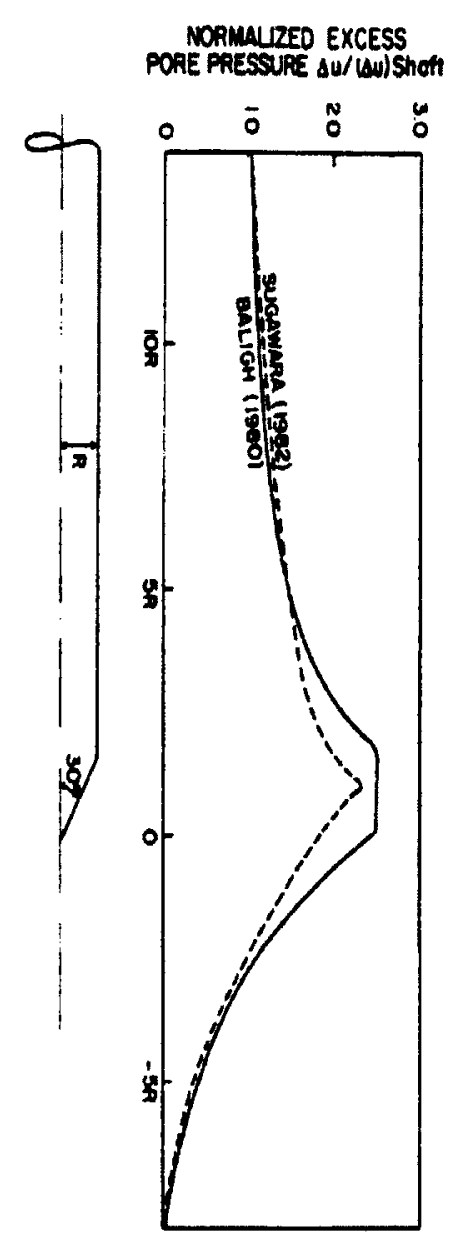

Figure 2.2: Variation of pore water pressure along the shaft of a cone (Tummay et al., 1982) 


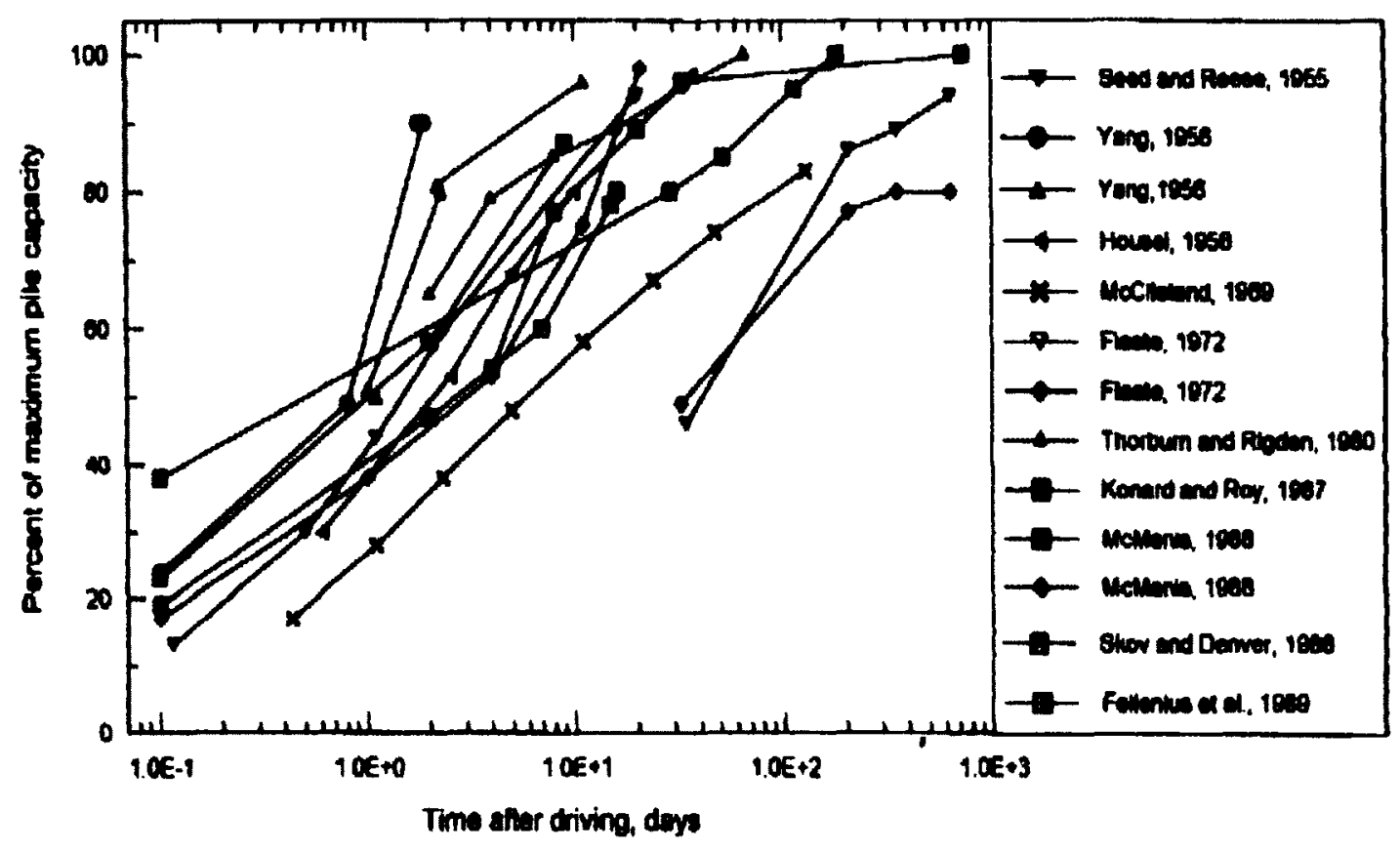

Figure 2.3: Pile bearing capacity increase with time for pile driven into clay

(Titi, 1996)

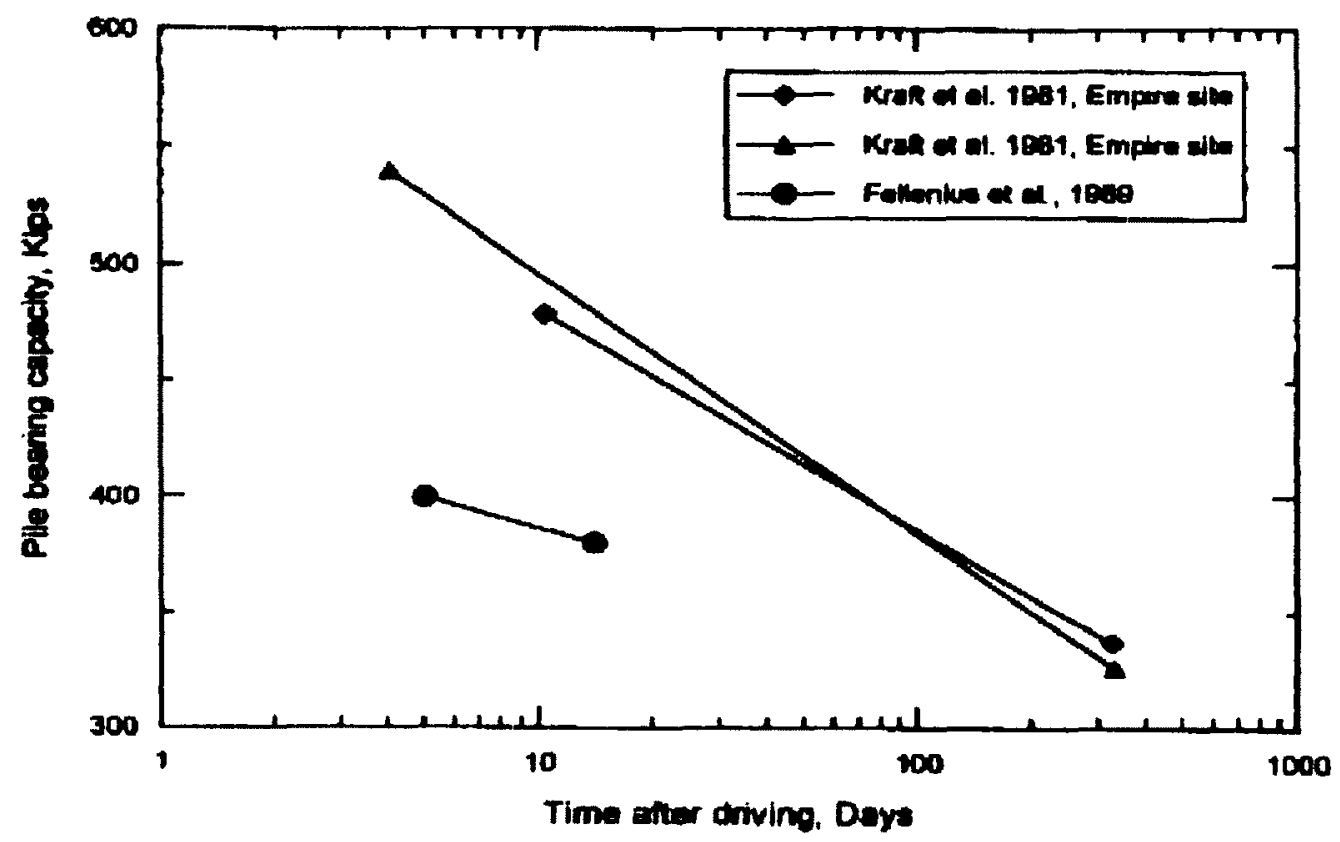

Figure 2.4: Pile capacity decrease with time after initial drive into the clay (Titi, 1996) 


\subsubsection{Pile setup mechanisms}

Komurka et al. (2003) idealized the total pile capacity increase in three phases (Figure 2.5). Phase 1 was defined as a fast and nonlinear rate with time due to the excess pore water dissipation in a relatively short period of time. During this phase of pile setup, the ratio of PWP dissipation with respect to the log of time is not constant. The duration of this phase is a function of both soil (type and permeability) and pile properties (size and permeability). This duration of nonlinear rate of dissipation is longer for less permeable soils and may last for several days in cohesive soils. At some time later, the rate of excess pore water pressure dissipation, and hence the setup rate, becomes logarithmically constant (linear). This linear rate of dissipation may continue for several weeks or even years for fine-grained soils (Skov and Denver, 1988). Azzouz, et al., (1990) reported that the complete consolidation of a $38 \mathrm{~cm}$ diameter pile may require 200-400 days.

After dissipation of excess pore water pressures, additional setup may occur due to ageing, and independent of effective stress (Phase 3). Ageing is a time-dependent change in soil properties at a constant effective stress and could be related to thixotropy, secondary compression, particle interference, and clay dispersion (Camp et al., 1999; Long et al., 1999; Schmertmann, 1991). Ageing can increase the pile-soil interface friction (McVay, 1999) at an approximately linear rate with the log of time (Schmertmann, 1991). 
In clayey soils, the rate of dissipation of pile driving-induced excess pore water pressure is slow. As a result, a small portion of setup is associated with non linear dissipation (Phase 1), while the majority of setup is associated with linear dissipation (Phase 2). Due to the mechanisms involved in ageing, Phase 3 may account for relatively little setup in clayey soils (Figure 2.5).

In fine-grained granular soils, the setup is mainly attributed to breakdown of the driving-induced arching mechanisms and ageing (Axelsson, 2002). Due to relatively rapid dissipation of excess pore water pressure, the majority of setup may be associated with ageing in these soils (Axelsson, 2002).

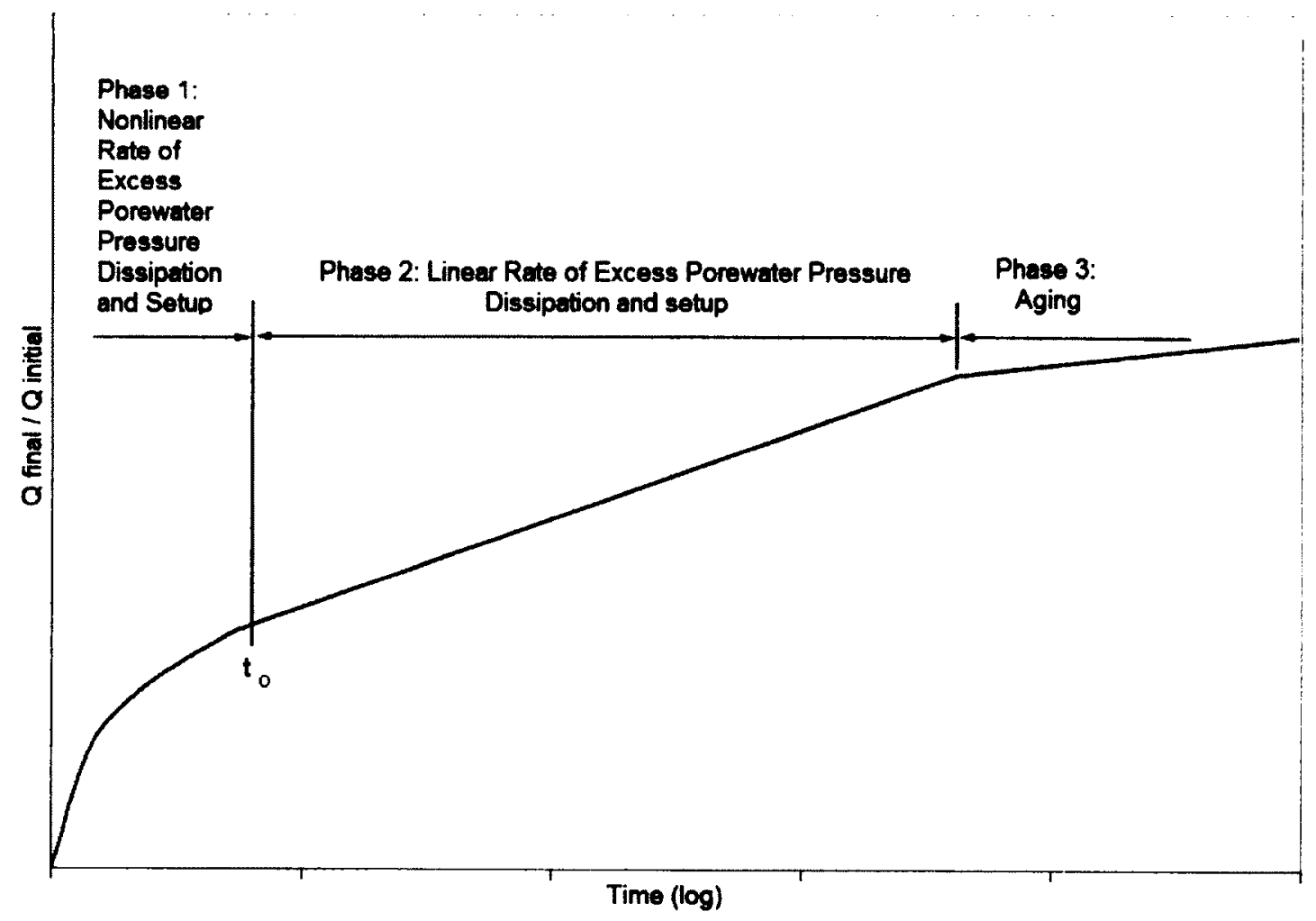

Figure 2.5: Idealized illustration of pile setup phases (Komurka et al., 2003) 
Soil ageing is not directly related to the soil density increase after pile driving but can be defined as strength and stiffness increase of the soil. In other words, soil ageing is described as relatively long term structure/fabric changes within soil particles and at the soil-pile interface zone. There are several theories to explain this phenomenon which at some cases are contradicted. The theories can be categorized in two major categories:

Cohesive behaviour of the soil caused by particles cementation

Friction increase caused by particle interlocking as a result of rearrangement Effect of cementation on pile capacity increase has been studied by researchers but mostly in larger particle soils such as sands and gravels (Sweeney et al., 1988; Dusseault and Morgenstern, 1979). Generally, cementation ratio in many soil types has a direct relation with the percentage of lime in the soil and its exposure to the water (Sweeney et al., 1988). In case of disturbance, cementation may happen after restructuring of the soil particles which will cause high shear or compressive strength of the soil with time. Same as cementation, friction between particles is mostly in effect in large particle soils like sand or any kind of soil with no cohesive bonding (Dusseault and Morgenstern, 1979). The contradiction was presented by Mesri (1990) and Schmertmann (1991) as cementation and rearrangement (creeping) cannot happen at the same time. 


\subsubsection{Pile setup in sensitive soils}

There are few studies on pile setup for driven piles in sensitive type of clay. Soil sensitivity is defined as the ratio of undisturbed to remolded undrained shear strength of the clay, which classifies the clay soil in three categories of low, medium and high sensitive soils. There are different phenomena contributing to develop soil sensitivity such as metastable structure, leaching, thixotropic hardening, cementation, ion exchange and monovalent/divalent cation exchange ratio. Thixotropic regain happens when there is a controlled condition, like when water content is consistent. As mentioned earlier, reduction in water content of soil surrounding the pile, after pile driving, was reported by some researchers (e.g., Seed and Reese, 1955; Flaate, 1968). Skempton and Northey (1952) presented a thixotropic regain reduction with water content reduction in soil when it is below liquid limit. They also showed that the strength of the clay was fully regained after one year for different clays (Detroit, London, and Shell haven clays). Mitchell (1960) discussed the major effective parameters on thixotropic behavior in clay. $\mathrm{He}$

presented parameters such as pore fluid composition, particle size and shape, and attractions and repulsions between clay particles to control the thixotropy in clay. There is no comprehensive theory regarding the mechanism of this phenomenon but Mitchell (1960) presented a supposition to explain the effect of thixotropy on clay. Mitchell (1993) characterized thixotropy as a reversible, time dependent, isothermal act that happens when composition and volume are consistent. As a result, material hardens at rest and softens when is disturbed or remolded. 


\subsubsection{Effect of pile-soil interface parameters on setup}

Another influencing factor in pile setup is soil-pile interface parameters. The soilpile system is highly influenced by soil behaviour in contact with the pile and stressdisplacement between them. In geotechnical structures, soil-structure interface is mostly a concern where a structure is subject of an axial load. Also, resistance against it is provided by friction parallel to the load direction, such as friction piles. Fioravante (2002), and Lehane and White (2005) observed the resistance/friction development in a very thin layer between soil and the structure which is called soil-structure interface. Their observation was based on experimental evidence performed using direct shear test. Potyondy (1961), Uesugi and Kishida (1986) and Tsubakihara and Kishida (1993) all agreed on the main influential factors on the soil-structure interface as follow:

$>$ Initial relative density

Initial normal stress

Particle shape (round or angular)

Soil grading

Soil-Structure interface surface roughness

Normalized roughness soil-structure has been defined by Uesugi and Kishida (1986) as a ratio of maximum roughness of the pile surface $\left(R_{t}\right)$ and the soil mean grain size $\left(R_{n}=R_{t} / 50\right)$. They reported this ration as the main factor to explain the failure mode and the maximum mobilized interface friction angle. 
Taha (2010) has studied steel- and concrete-soil interface shear behavior of sensitive marine clay (Leda clay). In case of Leda clay-steel interface, he exhibited that the interface friction angle is increased by increasing the Leda clay-steel interface roughness, OCR ratio and dry density of Leda clay. He also reported that Leda clay with lower saturation degree presents a higher interface shear resistance. Increasing the pore water salinity in Leda clay elevated the friction resistance, indicating that interface shear strength of Leda clay could be improved by chemical treatment. In case of Leda clayconcrete interface, increasing surface roughness, dry density and pore water salinity increased the interface friction angle.

\subsubsection{Magnitude of pile setup}

Piling is a very expensive portion of most construction projects and any saving at this sector would be highly considerable. Utilizing the share of pile setup in pile design may lead to a lighter and less expensive foundation system. Pile setup is affected by many parameters which has been formerly reviewed, and depending on these parameters, the amount of pile setup would be very variable. Figure 2.3 illustrates a series of previous data published on pile setup in literature. In majority of cases shown in this Figure, meaningful portion of the pile setup has been developed within 30 days after the initial driving, and the increase rate slows down afterwards till it is stabilized.

Various ranges of pile capacity increase have been reported in literature for the friction piles driven into clay-water system. In an investigation in southeast Louisiana, Blessey and Lee (1980) observed approximately 400 to $500 \%$ increase in shaft capacity a 
few weeks after initial pile driving. McManis et al. (1988) investigated pile setup on full scale concrete driven cylindrical and square piles at a site located in I-310 Luling Bridge near New Orleans, Louisiana. Piles were tested using Pile Dynamic Analyzer (PDA) as well as using static loading system. The result revealed that the bearing capacity increased five weeks after initial driving approximately 440 to $1150 \%$ (Figure 2.3 ).

Many parameters identified to affect the magnitude of setup include pile diameter, soil stiffness, moisture content, and installation procedure (Axelsson, 2002; Chow et al., 1998; Svinkin et al., 1994). In 1988, Skov and Denver observed a pile capacity increase of 20 to $100 \%$. Soil property was the effective parameter on this variation for pile setup. Yushkov and Bartolomy (1985) reported a shear strength increase of 70 to $80 \%$ within 6 to 45 days after initial drive for displacement single piles and also groups of 4 and 9 piles driven into clay.

Pile materials were also shown to affect the rate and magnitude of setup. Concrete piles were reported to exhibit more setup than steel piles. This has been related to a higher pile-soil interface friction and higher permeability of the concrete compared to steel (Preim and Hussein, 1989). Pile type could also affect the setup by providing different amount of displacement in the surrounding soil. After 10 to 32 days of driving, an increase of $25 \%$ on pile capacity was observed on pipe piles and H-piles driven into stiff Chicago clay and $50 \%$ increase within 10 to 32 days after driving on piles driven into soft Chicago clay (Lukas and Bushell, 1989). In very few cases, negative setup or relaxation was observed due to existence or negative pore water pressure developed by pile driving. This condition has been reported mostly in non-cohesive soils and only in 
highly overconsolidated clays (Bond and Jardin, 1991).

Pile setup for driven piles in sensitive clay is relatively small compared to the pile setup for piles driven in insensitive clay. For example, Skempton and Northey (1952) concludes that pile driven in sensitive clay regains its full strength after a year due to thixotropic effect while Seed and Reese (1955) reports $540 \%$ pile setup after thirty days for piles driven into insensitive clay due to reconsolidation of surrounding soil. In conclusion, thixotropic is an unclear phenomenon and has a very minor effect on pile setup compared with the effect of reconsolidation.

\subsubsection{Pile setup in group piles}

In many cases, piles are employed in groups. Applied load to a group of piles is distributed non linearly and indeterminately to the soil which makes pile group behaviour more complicated, and this complex situation would be different when piles are subjected to an axial compression or an axial uplift loading. Soderberg (1962) explained a theory regarding pile group effect on setup. As per his study, if a ring of piles were driven around a single pile, generated excess pore water pressure and its dissipation rate would be increased compared to the original value of a single pile. Later, Poulos and Davis (1980) proposed that the generated pore pressure due to surrounding pile driving would superimpose to the pore water pressure but it will get to a maximum as much as what 
generated by driving a single pile. Although, the effected zone, where the excess pore water pressure needs to be dissipated, is larger and hence the dissipation would be more time consuming. Vesic (1977) believed that the rate of pile capacity gain is much slower for a group of driven piles compared to one single pile.

O'Neill (1983) conducted an extensive study on pile group behaviour in the field. According to his observation, a pile-group driven in normally or over consolidated sensitive clay, tends to generate more (about $25 \%$ ) pore water pressure, while group pile driven in insensitive-overconsolidated clays generated pore water pressure about the same as a single driven pile situation (Figure 2.6). ONeill (1983) also reported that the order of pile driving in a group of piles can effect pore water generation and dissipation. It should also be noted that pile driving order and time elapsed between each couple of piles in a group can be another effective parameter in pore water pressure dissipation (O'Neill, 1983). As a result, setup time and pile setup capacity would be affected. 

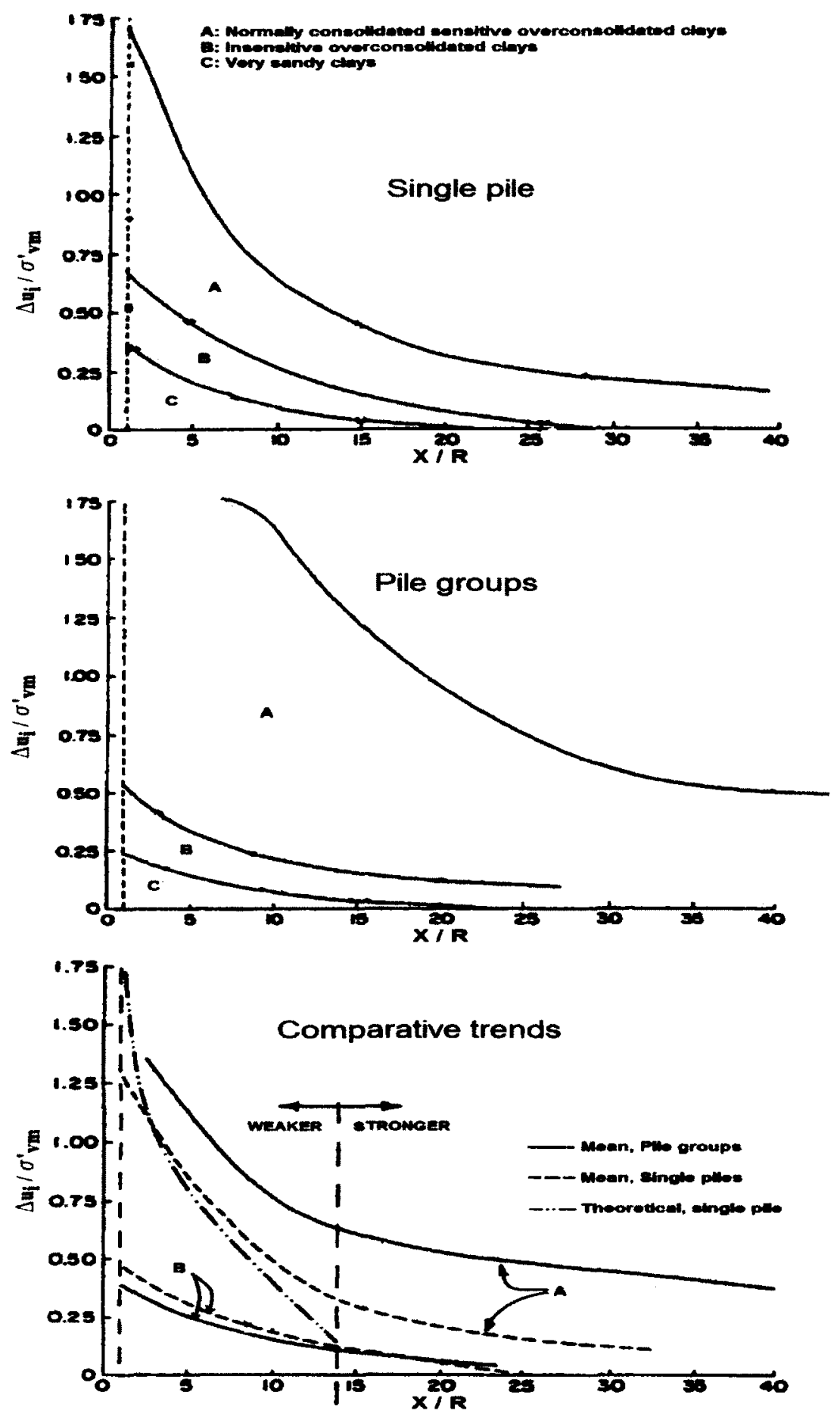

Figure 2.6: Pore water pressure generation around a single and group of piles

$\Delta u_{i}=$ initial pore water pressure, $\sigma^{\prime}{ }_{v \mathrm{~m}}=$ vertical preconsolidation pressure, $X=$ radical distance from pile centre, $R=$ pile radius ( $O^{\prime} N$ eill, 1983) 


\subsubsection{Pile setup in displacement versus non-displacement piles}

Observation on full scale field results in industry indicates that displacement piles and non-displacement piles possess a slightly different behaviour in terms of pile setup rate. Regardless of pile material, piles are classified in two major categories of "displacement piles" such as closed end steel pipe piles or "non-displacement piles" such as open toe steel pipe piles or H-piles. Some type of piles can be placed in between these two major categories, like Pre-stressed Spun Concrete Piles (Also known as ICP-PSC piles) which are basically hollow sections with a thick wall. These types of piles can behave as displacement pile or non-displacement pile based on the soil type they are driven into.

Different effects of pile driving using closed end pipe piles versus unpluggedopen end pipe pile was investigated by Carter et al. (1980). By using numerical models, he presented an equation to quantify the displaced soil. By comparing the displaced soil in each case, he concluded that the more soil displacement occurs, the more stress changes and as a result the longer reconsolidation would be. Conversely, final soil strength surrounding the closed end pile is higher compared to the open end pile.

\subsection{Prediction of pile setup}

As mentioned earlier, pile setup could increase pile capacity as much as $50 \%$ (or more) which is a considerable factor on pile design and may save a project an enormous amount of material, labour and cost. A vast variety of approaches have been retained to explain and predict pile setup, such as empirical methods, numerical modelling etc., but there is 
no universal solution to predict pile setup for all situations. All presented solutions are limited to a specific condition, or developed through a limited data set. This section tends to review the proposed prediction solutions using different approaches on pile setup.

Peck (1958), Woodward et al. (1961), Tomlinson (1971), Flaate (1972) and McClleland (1972) proposed a prediction using total stress approach. On the other hand, Zeevaert (1959), Eide et al. (1961), Chandler (1968), Burland (1973), Meyerhof (1976), Flaate and Selnes (1977) and Parry and Swain (1977) used effective stress method to predict pile shaft capacity. Both the total and effective stress approaches consider pile capacity at one stage, and there is no consideration of elapsed time.

Esrig et al. (1977) introduced effective stress theories in different stages to predict pile-soil behaviour. Critical state soil mechanics theory was used to predict the pile capacity by Kirby and Wroth (1977). Also, Carter et al. (1979), Randolph et al. (1979), Randolph and Wroth (1979) and Wroth et al. (1979) used cavity expansion methods and constitutive model in numerical and analytical methods to explain the soil behaviour around the pile. Banerjee et al. (1982), Roy et al. (1981), Azzouz and Lutz (1986), Coop and Wroth (1989), Bogard and Matlock (1990), Bond and Jardine (1991), Wathugala et al. (1993) approached experimental research and fabricated methods such as instrumented piles and small scale piles to study pile behaviour. As a result, effective stress state demonstrated a very important role to predict shaft capacity. Considering the time after driving and pile life stage proved to have a significant effect on pile capacity for friction piles. Figure 2.7 shows an example general trend of pile capacity increase over time for a driven pile in cohesive soil (Paikowsky et al., 1995). 
Several researchers attempted to estimate and the pile setup using one-dimensional consolidation theory proposed by Terzaghi (1943). The theory is applicable when a load is applied into a homogeneous and saturated soil and soil particles are incompressible. It also assumes the strains, velocities and stress increments are small and soil is confined laterally and there is an unlimited pore fluid source. In such a situation, there is a linear stress-strain relation in the soil structure, and dissipation of pore water pressure causes volume reduction of soil mass. As described formerly, excess pore water pressure generated during pile driving dissipates in the surrounding soil over time caused the soil to consolidate. Thereupon, shear strength of the soil adjacent to pile is increased due to the consolidation which will result in pile capacity increase.

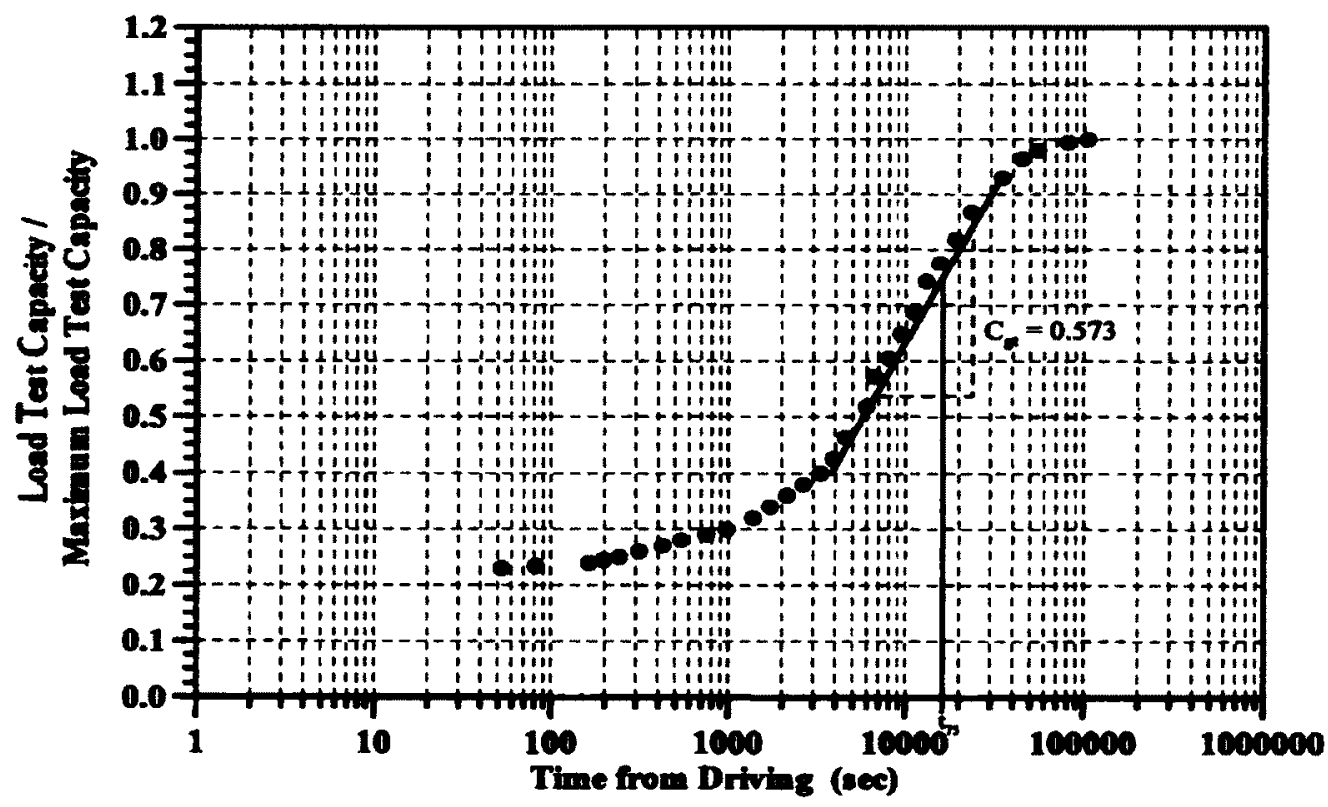

Figure 2.7: Example of pile capacity increase with time ( $C_{\mathrm{z}}$ : setup parameter)

(Paikowsky et al., 1955) 
Several empirical equations have been proposed to quantify the magnitude of pile setup. The most-popular one was proposed by Skov and Denver (1988), which introduced a linear relationship between logarithm of time and pile setup. This equation is based on three case histories of dynamic and static load testing on driven piles in different types of soil, including clay.

$$
Q / Q_{0}=1+A \log \left(t / t_{0}\right)
$$

where $Q$ is pile capacity at the time $t$ after driving, $Q_{0}$ is pile capacity at initial time $t_{0}$, $A$ is the coefficient of relative increase in pile capacity for log time cycle which as a common term, is called Setup Factor. This factor varies based on soil and pile type, pile size and driving technique. Table 2.1 presents variation of the setup factor, $A$, for different soil and piles.

A number of equations were also proposed by other researchers to estimate the pile setup. Table 2.2 summarizes the empirical equations used to estimate the pile capacity in soft soils. Guang-Yu (1988) proposed an equation for pile capacity of driven into soft soils. The relationship was developed based on the sensitivity of the fine-grained soil for capacity 14 days after driving. Huang (1988) suggested an equation for predicting setup rate in the soft soil of Shanghai. Similar to the Skov and Denver relationships, all these formulas were developed using combined shaft and toe resistance data. Unlike the Skov and Denver relationship, these formulas all consider the pile capacity immediately after driving, $Q_{\mathrm{EOD}}$, which can be determined by dynamic monitoring (Table 2.2). 
There are some studies which explain pile setup using cavity expansion theory. (Vesic, 1972; Van den Berg, 1994; Mayne and Bachus, 1988). CAMbridge (onedimensional Finite Element program) was used to model stress and pore water pressure changes in modified Cam-clay system due to cavity expansion while consolidated (Randolph et al., 1979). Strength and water content changes were estimated for the soil around the driven pile. This study utilized that the increase rate of bearing capacity may be estimated from increase rate of shear strength of the adjacent soil of a driven pile (Figure 2.8).

Table 2.1: Various value for $A$ and $t_{0}$ parameters ( Skov and Denver, 1988)

\begin{tabular}{c|c|c|c|c}
\hline Author & Soil conditions & $\mathrm{A}$ & $\begin{array}{c}\mathrm{T}_{0} \\
\text { (day) }\end{array}$ & $\begin{array}{c}\text { Pile Type/ } \\
\text { Location }\end{array}$ \\
\hline $\begin{array}{c}\text { Yang and Liang } \\
(2006)\end{array}$ & Clayey soils & 0.5 & 1 & $\begin{array}{c}\text { Pipe, HP, concrete, } \\
\text { timber, etc./various }\end{array}$ \\
\hline $\begin{array}{c}\text { Bullock et al. } \\
(2005)\end{array}$ & $\begin{array}{c}\text { Dense fine sand and } \\
\text { soft to medium stiff } \\
\text { silty clay }\end{array}$ & 0.2 & 1 & $\begin{array}{c}\text { Concrete piles /North } \\
\text { Florida }\end{array}$ \\
\hline $\begin{array}{c}\text { Camp and Parmar } \\
(1999)\end{array}$ & $\begin{array}{c}\text { Stiff, highly plastic } \\
\text { sandy clay or sandy silt } \\
\text { (Cooper Marl) }\end{array}$ & $0.37-1.31$ & 2 & $\begin{array}{c}\text { Concrete piles, H- } \\
\text { piles/Charleston, South } \\
\text { Carolina }\end{array}$ \\
\hline $\begin{array}{c}\text { Skovand Denver } \\
(1988)\end{array}$ & Clay & 0.2 & 0.6 & $\begin{array}{c}\text { Concrete piles/ } \\
\text { Alborg, Denmark }\end{array}$ \\
\hline $\begin{array}{c}\text { Svinkin et al. } \\
\text { (1994) }\end{array}$ & Clayey and soils & $0.36-1.07$ & 1 or 2 & $\begin{array}{c}\text { Pre-stressed concrete } \\
\text { piles and H-piles/Ohio }\end{array}$ \\
\hline
\end{tabular}


Table 2.2: Additional equations for setup prediction

\begin{tabular}{c|c|l}
\hline Author & Equation & \multicolumn{1}{c}{ Comments } \\
\hline $\begin{array}{c}\text { Svinkin and } \\
\text { Skov (2000) }\end{array}$ & $\mathrm{R}_{\mathrm{u}}(\mathrm{t}) / \mathrm{R}_{\mathrm{EOD}}-1=\mathrm{B}\left[\log _{10}(\mathrm{t})+1\right]$ & $\begin{array}{l}\mathrm{B}=\text { similar to A in } \\
\text { Denver and Skov }\end{array}$ \\
\hline Huang (1988) & $Q \mathrm{t}=Q_{\mathrm{EOD}}+0.236\left(1+\log (t)\left(Q_{\max }-Q_{\mathrm{EOD}}\right)\right)$ & $\begin{array}{l}\mathrm{Q}_{\mathrm{t}}=\text { capacity at time } \mathrm{t} \\
\mathrm{Q}_{\mathrm{EOD}}=\text { capacity at EOD } \\
\mathrm{Q}_{\max }=\text { Maximum capacity }\end{array}$ \\
\hline $\begin{array}{c}\text { Guang-Yu } \\
(1988)\end{array}$ & $\mathrm{Q}_{14}=\left(0.375 \mathrm{~S}_{\mathrm{t}}+1\right) \mathrm{Q}_{\mathrm{EOD}}$ & $\begin{array}{l}\mathrm{Q}_{14}=\text { capacity after } 14 \text { days } \\
\mathrm{S}_{\mathrm{t}}=\text { Sensitivity of soil }\end{array}$ \\
\hline $\begin{array}{c}\text { Svinkin } \\
(1996)\end{array}$ & $\mathrm{Q}_{\mathrm{t}}=1.4 \mathrm{Q}_{\mathrm{EOD}} \mathrm{t}$ & Upper Bound \\
\cline { 2 - 3 } & $\mathrm{Q}_{\mathrm{t}}=1.025 \mathrm{Q}_{\mathrm{EOD}} \mathrm{t}$ & Lower Bound \\
\hline
\end{tabular}

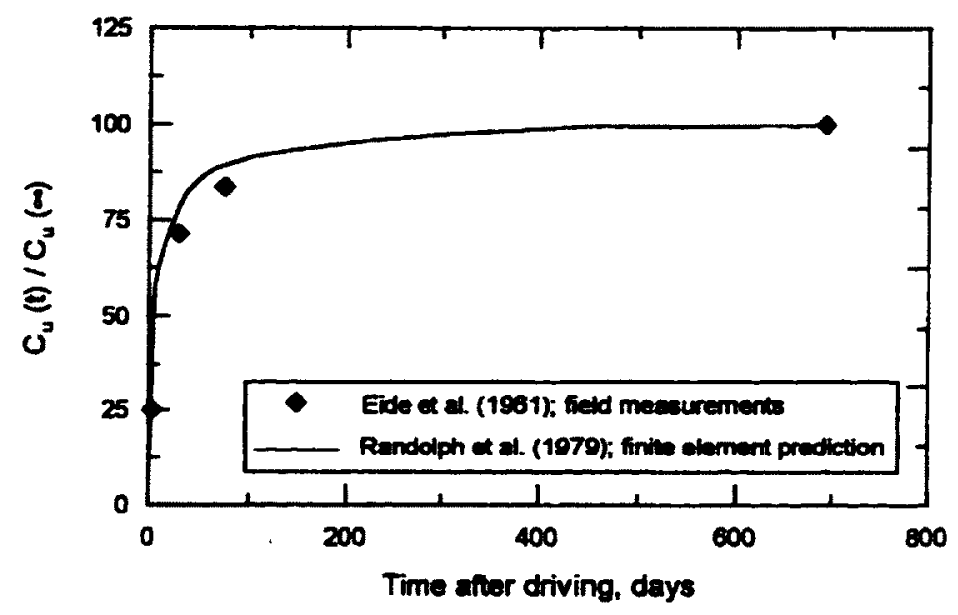

(a)

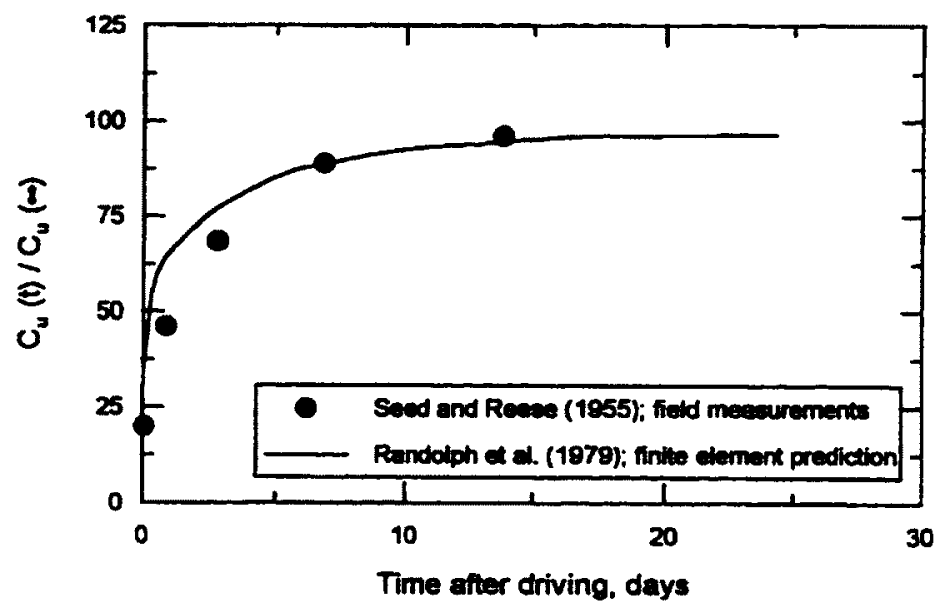

(b)

Figure 2.8: Comparison of measured pile setup with theoretical setup capacity for (a) Driven pile into Draummen clay, (b) Driven pile into San Francisco Bay mud (after Randolph et al., 1979) 
Also Banerjee et al. (1982) investigated behaviour of piles driven into the saturated clay using experimental data, theoretical and numerical methods. The instrumented pile provided information regarding stress, excess and dissipation of pore water pressure while driven and after driving. Numerical analysis performed as a rigid, smooth and cylindrical pile into a modified Cam-clay system. Furthermore, theoretical solution described plane strain expansion of the cylindrical cavity. Result offered an agreement between cavity expansion and experimental data from instrumented pile at the pile interface with soil but not with the boundary soil.

Another approach to predict pile setup is through utilizing the fundamental of shear strength. As a general equation, total skin friction resistance of a pile is calculated as:

$$
Q_{s}=\sum f s p \Delta L
$$

where $p$ is pile parameter, $L$ is the pile length and $f_{s}$ is defined as the unit friction resistance between soil and pile skin. $f_{s}$ is estimated based on laboratory testing, i.e., pile testing which are independent of the time. To employ the effect of pile behaviour in different time stages, $f_{s}$ may also be calculated using Equation 2.3 which is dependent on time:

$$
f s(t)=\left(1-\sin \varphi^{\prime} R(t)\right) \tan \varphi^{\prime} R(t) O C R_{R}^{\sin \varphi^{\prime}}(\sigma z-u(t))
$$


where $O C R$ and $s_{z}$ are determined by any type of subsurface investigation such as CPT or lab testing, $u(t)$ is defined using existing models or subsurface investigations, and $\phi_{R}^{\prime}(t)$ is defined as residual friction angle. The time dependant $\phi^{\prime} R(t)$ is calculated using equation 2.4:

$$
\varphi^{\prime} R=a 0 O C R^{a} l \log (t / t 0)+\varphi^{\prime} R 0
$$

where $t / t_{0}$ is defined as time ration, assuming $u\left(t_{0}\right)$ is a constant parameter, $\phi_{\mathrm{R} 0}$ is initial remolded friction angle and is determined using experimental testing. $a_{0}$ and $a_{l}$ are soil characteristic coefficients; $a_{l}$ (time factor) and $a_{0}$ (consolidation factor) can be determined by iterative OCR testing. This equation was verified using field data from five instrumented piles driven in north Florida and monitored over five years by Bullock's (1999). Also $\phi_{\mathrm{R}}^{\prime}(\mathrm{t})$ was verified by using direct shear apparatus.

\subsection{Summary}

The literature presented here provides the research background and theories which have been utilized to describe the pile driving in clay-water system and specifically pile capacity transition with time. Soil disturbance and remolding is caused while pile is penetrated into a clay-water system. The occurred disturbance leads to an excess pore water pressure generation and soil shear strength reduction. Immediately after pore water pressure generation, the generated PWP tends to dissipate and stabilize the clay-water system. After system stabilization, in majority of situations, soil shear strength and pile capacity increases with time. This increase in pile capacity is called pile setup or freeze. 
Reviewing extensive studies and research that have been done on pile setup, illustrates the importance of the subject and its effect in the pile design. Pile setup was shown to be affected by soil and pile types, rate of loading and pile-soil interface properties. In majority of the cases an increase in capacity with time has been reported in literature, however, a decrease in capacity with time was reported for dense to very dense fine sands. The magnitude of the setup varies significantly depending on the soil and pile types, but on average a capacity increase up to $50 \%$, or more, of the initial pile capacity has been reported for piles in fine-grained soils.

Many empirical formulas have been proposed to estimate the pile setup. Several researchers have attempted to simulate and estimate the setup utilizing consolidation theory, cavity expansion or fundamental of shear strength at the pile-soil interface zone. Although this rich literature provides an insight to the subject of the pile setup, however, the exact mechanism of setup is not well understood. The prediction relationships provide information on some specific soil at a specific location and are used and are representative for where it has been studied, and still there is a need for a vast investigation to predict a reliable setup rate for driven piles in wide range of applications. Therefore, this research has tendency to investigate this phenomenon in two different types of clayey soils existed in central-east Canada. 


\section{CHAPTER :3 EVALUATION OF PILE SETUP IN WINNIPEG}

\section{CLAY*}

\subsection{Overview}

As discussed earlier, pile capacity increase is not incorporated in current pile design procedures due to lack of full understanding of the mechanisms of capacity augmentation, and the effect of several factors such as soil type, pile material and installation method. To develop a better insight into the characteristics of stress-strain and frictional behaviours of piles over time, laboratory testing of soils sheared against other materials can be used. This experimental program tends to examine the evolution of pile-soil interface strength over time for both concrete-soil and steel-soil interactive systems in undisturbed soil using direct shear tests. The evolution of strength with time was compared with those achieved in the large scale pile load tests in the field.

\subsection{Obtaining the soil Sample}

South Winnipeg, Manitoba is known for existence of a thick deposited layer of soft clay. Soil samples used in this investigation were obtained from a project site in town of

* A version of this Chapter has been tentatively accepted for publication in ASTM Geotechnical Testing Journal. 
Altona, about $125 \mathrm{~km}$ south of Winnipeg, in Manitoba (Figure 3.1). A series of undisturbed block samples were taken from the base of a trench at the depth of 2.5 meters. The soil samples were stored in sealed plastic containers and shipped to Geotechnical laboratory of the Carlton University, Ottawa, ON.

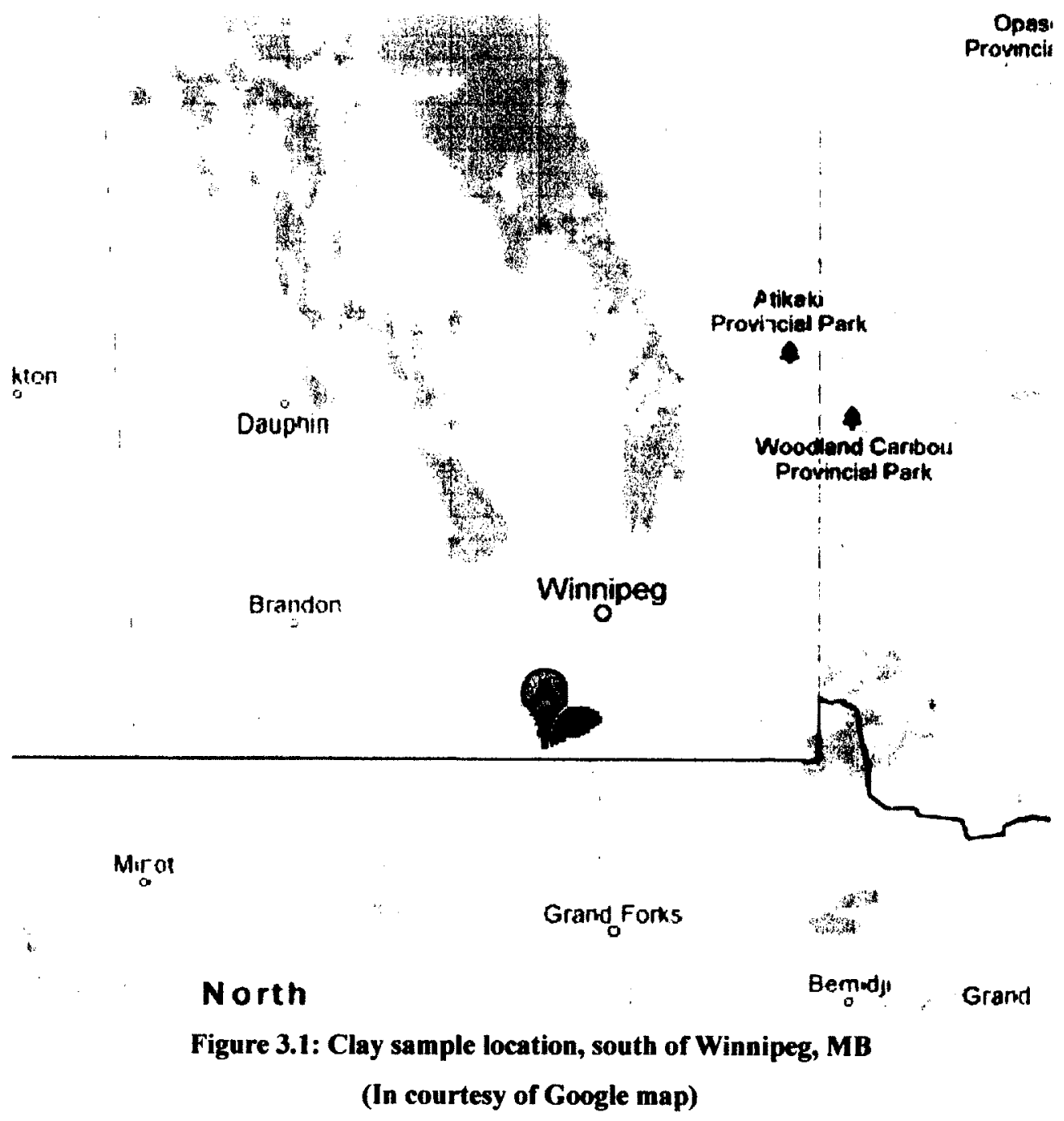




\subsection{Soil properties}

A series of grain size analysis, Atterberg and compaction tests were conducted to determine the soil index properties. The particle size distribution, in the course portion was obtained using ASTM D 422 (as shown in Figure 3.2). Also, a hydrometer test (ASTM D422) was used to obtain the particle size distribution in the fine portion (Figure 3.2). These data indicated that the soil has approximately $71 \%$ fine fraction (passing $0.075 \mathrm{~mm}$ sieve) and about $36 \%$ clay fraction. Besides, the plasticity index of the fine portion was determined about $37 \%$ based on ASTM D 4318.

As noted, the soil can be classified as CH in USCS classification system (ASTM D2487). The standard proctor compaction test (ASTM D 698) showed a maximum dry density of $1.74 \mathrm{mg} / \mathrm{m}^{3}$ at optimum gravimetric water content of $22 \%$. The coefficient of soil consolidation was achieved through an odometer test (ASTM D2435) which showed a value of $4.8 \times 10^{-4} \mathrm{~cm}^{2} / \mathrm{s}$. Vane shear test (ASTM D2573) was also employed to estimate the undrained shear strength of both undisturbed and remolded soil. Soil sensitivity of 4.2 was calculated which is classified as low sensitive clay. Table 3.1 shows a summary of the index properties of the soil used in this study.

Table 3.1: Index properties of soil samples, South-Winnipeg, MB

\begin{tabular}{|c|c|c|c|c|c|c|c|c|}
\hline $\begin{array}{c}\rho \\
\left(\mathbf{M g} / \mathrm{m}^{3}\right)\end{array}$ & $\begin{array}{c}w \\
(\%)\end{array}$ & $\begin{array}{l}\text { LL } \\
(\%)\end{array}$ & $\begin{array}{l}\text { PI } \\
(\%)\end{array}$ & $\begin{array}{l}w_{\text {opt }} \\
(\%)\end{array}$ & $\begin{array}{c}\rho_{d(\max )} \\
\left(\mathrm{Mg}^{3} / \mathrm{m}^{3}\right)\end{array}$ & $\begin{array}{c}C_{v} \\
\left(\mathrm{~cm}^{2} / \mathrm{s}\right)\end{array}$ & $\begin{array}{c}S_{u} \\
(\mathbf{k P a})\end{array}$ & $\begin{array}{c}S_{u r} \\
(\mathbf{k P a})\end{array}$ \\
\hline 1.83 & 43 & 70 & 37 & 22 & 1.74 & $4.8 \times 10^{-4}$ & 55 & 13 \\
\hline
\end{tabular}




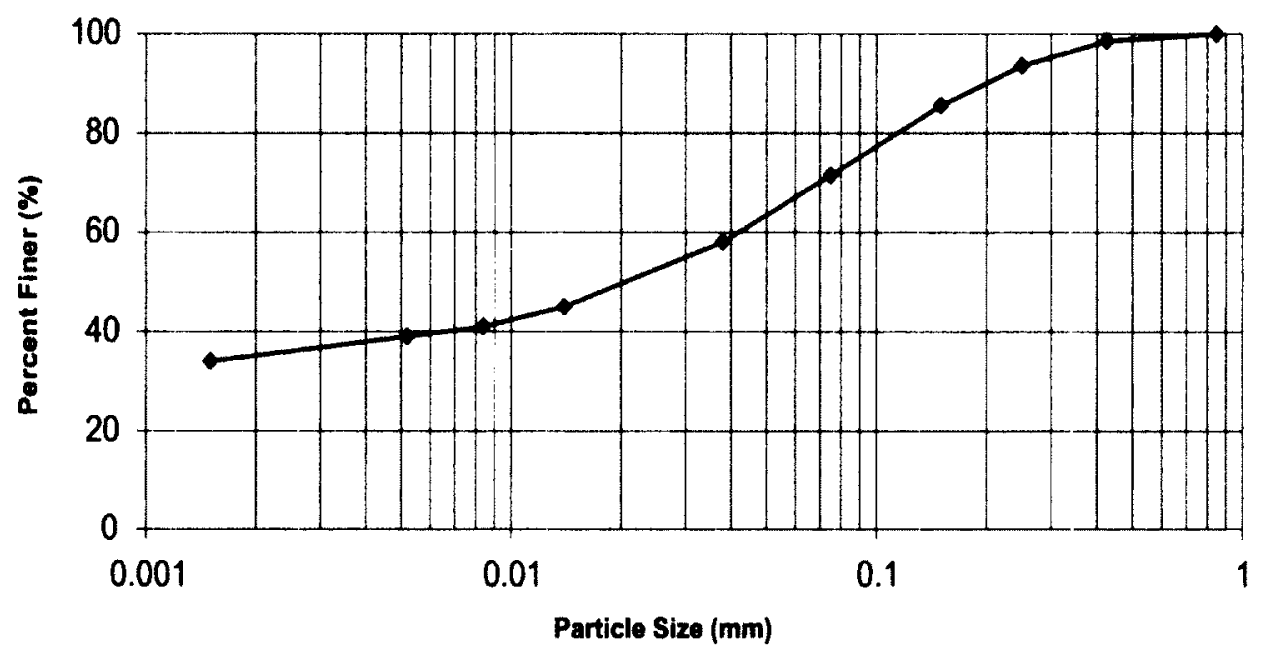

Figure 3.2: Grain size distribution of South-Winnipeg Clay

\subsection{Experimental procedure}

The bearing capacity of frictional piles is relevant to the ultimate shearing resistance at the interface between the soil and pile. This interface shearing resistance is generally different from the residual strength of the soil itself, and depends on the interface material and its roughness as well as on the properties of the soil, the magnitude of the normal stress and the rate of shear displacement (Lemos and Vaughan, 2000).

A displacement-controlled direct shear test with a $60 \mathrm{~mm}$ square shear box was used to simulate shear behaviour in the interface of the pile and its surrounding soil. The data generated from this size of apparatus are considered reliable according to the finding of O'Rourke et al. (1990) which demonstrated that the size of test plate (from 60 to 305 $\mathrm{mm}^{2}$ ) has no influence on the values of the interface friction angles between soil and solid 
surfaces. The shear tests were performed in both settings of soil only (soil-soil) and soilinterface specimens in accordance with ASTM 3080 and ASTM 5321, respectively. In the interface tests, soil samples were sheared against concrete and steel planes confined by the bottom half of the box in the direct shear apparatus, while the upper half of the box confined the soil (Figure 3.3). The concrete contained fine sand and cement which provides same surface texture as prototype concrete pile. For preparation of the concrete plane, a Plexiglas plate was used on the surface of the concrete in order to achieve a smooth surface. 4 square steel plates of about $25 \mathrm{~mm}$ in thickness were fabricated to be fitted into the lower container of the conventional direct shear test apparatus. The pilesoil shearing resistance was shown to be dependent on the interfaces' roughness (Lemos, 1986). Both the steel plate and cast concrete used in the tests had relatively smooth surfaces. The surface roughness of the steel plate and concrete was measured retaining a FARO ${ }^{\circ}$ arm measuring device. The average roughness $\left(R_{a}\right)$ of steel plate and concrete were computed at 10.7 and $9.1 \mathrm{~mm}$, respectively (Figure 3.4). Table 3.2 indicates the details of the experiments as well as the type of tests performed on each of them. 


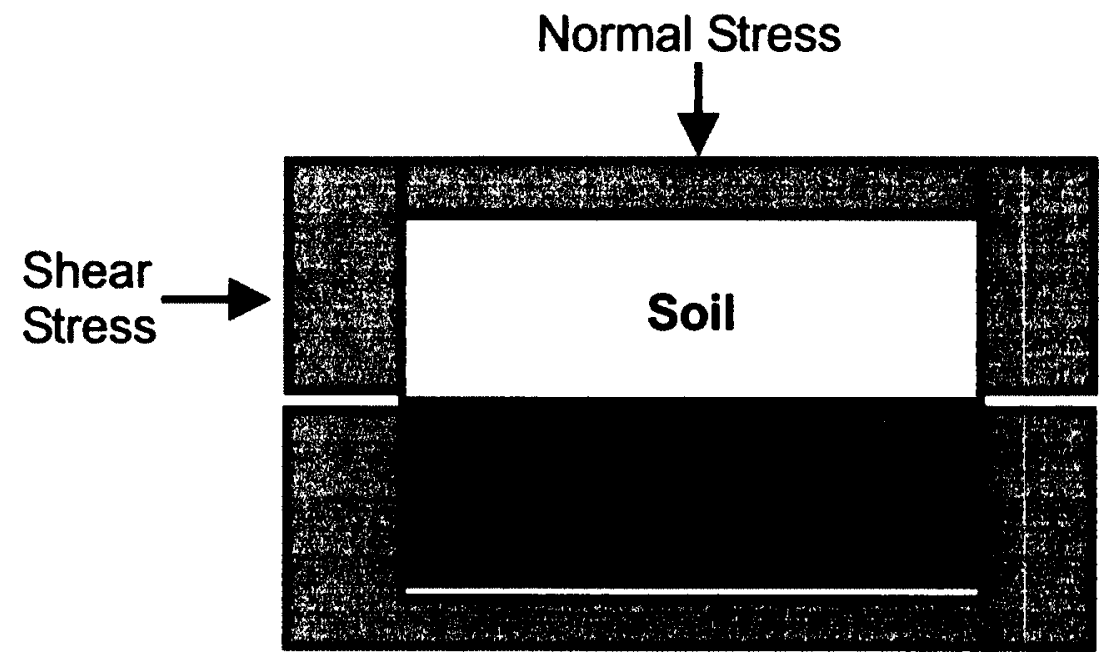

Figure 3.3: Schematic view of the direct shear apparatus for interface tests

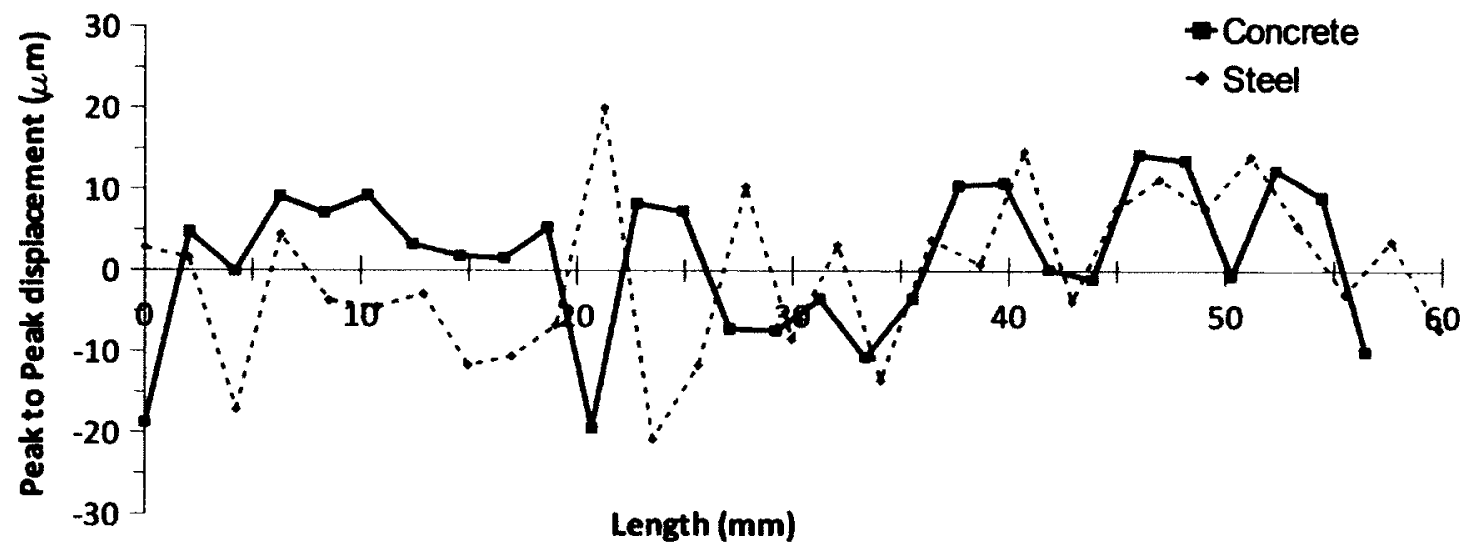

Figure 3.4: Surface Roughness for concrete and steel, using FARO arm 
Table 3.2: Details of soil and interface shear tests

\begin{tabular}{|c|c|c|c|c|c|c|c|c|c|c|c|c|c|}
\hline Test & $\sigma$ & \multicolumn{4}{|c|}{ Soil-soil } & \multicolumn{4}{|c|}{ Steel-soil } & \multicolumn{4}{|c|}{ Concrete-soil } \\
\hline $\begin{array}{c}\text { Ela } \\
\text { pse } \\
\text { d } \\
\text { time }\end{array}$ & $(\mathrm{kPa})$ & $\begin{array}{c}\tau p \\
(\mathrm{kPa})\end{array}$ & $\begin{array}{c}\tau \mathrm{r} \\
(\mathrm{kPa})\end{array}$ & $\begin{array}{l}\varphi p \\
\left(^{\circ}\right)\end{array}$ & $\begin{array}{l}\varphi r \\
\left(^{\circ}\right)\end{array}$ & $\begin{array}{c}\tau p \\
(\mathrm{kPa})\end{array}$ & $\begin{array}{c}\tau r \\
(\mathrm{kPa})\end{array}$ & $\begin{array}{l}\delta p \\
\left(^{\circ}\right)\end{array}$ & $\begin{array}{l}\delta \mathrm{r} \\
\left(^{\circ}\right)\end{array}$ & $\begin{array}{c}\tau p \\
(\mathrm{kPa})\end{array}$ & $\begin{array}{c}\tau r \\
(\mathrm{kPa})\end{array}$ & $\begin{array}{l}\delta p \\
\left(^{\circ}\right)\end{array}$ & $\begin{array}{l}\delta r \\
\left(^{\circ}\right)\end{array}$ \\
\hline $\begin{array}{l}\text { ini- } \\
\text { tial }\end{array}$ & $\begin{array}{c}60 \\
90 \\
150\end{array}$ & $\begin{array}{c}21 \\
29.5 \\
59.9\end{array}$ & $\begin{array}{c}21 \\
29.5 \\
56\end{array}$ & 23.9 & 23.6 & $\begin{array}{l}10.7 \\
11.6 \\
14.1\end{array}$ & $\begin{array}{l}10.7 \\
11.5 \\
14.1\end{array}$ & 2.5 & $\begin{array}{l}2.5 \\
2.5\end{array}$ & $\begin{array}{l}17.5 \\
23.9 \\
34.5\end{array}$ & $\begin{array}{c}12 \\
22.5 \\
31.2\end{array}$ & 11.7 & 12.6 \\
\hline $\begin{array}{c}\text { l } \\
\text { day }\end{array}$ & $\begin{array}{c}60 \\
90 \\
150\end{array}$ & - & - & & & $\begin{array}{c}15.8 \\
16 \\
22.2\end{array}$ & $\begin{array}{c}13 \\
15.8 \\
19\end{array}$ & 4.8 & 4.0 & $\begin{array}{c}16 \\
25.7 \\
49.5\end{array}$ & $\begin{array}{c}14.5 \\
26 \\
\\
39.5\end{array}$ & 22.5 & 16.6 \\
\hline $\begin{array}{c}4 \\
\text { day } \\
\text { s }\end{array}$ & $\begin{array}{c}60 \\
90 \\
150\end{array}$ & - & - & & & $\begin{array}{c}14.5 \\
17.5 \\
31\end{array}$ & $\begin{array}{l}13.5 \\
17.4 \\
22.7\end{array}$ & 11.3 & 6.3 & $\begin{array}{c}15 \\
31.5 \\
56\end{array}$ & $\begin{array}{l}14.9 \\
30.5 \\
46.7\end{array}$ & 6.3 & 20.6 \\
\hline $\begin{array}{c}11 \\
\text { day } \\
\text { s }\end{array}$ & $\begin{array}{r}60 \\
90 \\
150\end{array}$ & - & - & & & $\begin{array}{c}14.9 \\
18 \\
25\end{array}$ & $\begin{array}{c}14.2 \\
17.5 \\
25\end{array}$ & 7.1 & 7.6 & $\begin{array}{c}19 \\
45.3 \\
58.8\end{array}$ & $\begin{array}{c}16.6 \\
39 \\
\\
54.3\end{array}$ & 24.4 & 23.5 \\
\hline
\end{tabular}

$\sigma=$ normal stress; $\tau_{\mathrm{p}}=$ peak shear stress; $\tau_{\mathrm{r}}=$ residual shear stress; $\varphi_{\mathrm{p}}=$ soil peak friction angle; $\varphi_{\mathrm{r}}=$ soil residual friction angle; $\delta_{\mathrm{p}}=$ peak interface friction angle; and $\delta_{\mathrm{r}}=$ residual interface friction angle 
After setting up the surfaces, mechanical actuators were employed to apply lateral loads which were measured with electronic load cells, a linear variable differential transformer (LVDT) and a dial gauge that measures lateral and vertical displacements, respectively. The experimental apparatus is schematically illustrated in Figure 3.3. Three sets of normal stresses $(60,90$, and $150 \mathrm{kPa})$ were imposed upon the pile-soil system to recreate the overburden pressure in the field, and to consolidate the soil. The static horizontal stresses were applied at a displacement rate of $0.01 \mathrm{~mm}$ per minute, which constitutes drained loading conditions. Thus, the model clay for pile-soil interface tests is discussed in terms of effective stress.

\subsection{Result and discussion}

\subsubsection{Initial interface parameters}

Direct shear test results, in terms of shear stress versus horizontal displacement curves for both soil-soil and soil-interface systems are presented in Figure 3.5. For the entire range of normal pressures tested, the direct shear tests exhibited a peak shear stress followed by a small stress reduction toward a residual shear stress with a nearly constant volume state. Although the interface strengths are not the same, curves for concrete-soil interface tests (Figure 3.5c) are similar to those of the clay sheared alone. The stress-displacement curves for the steel-soil interface are shown to be different, especially at the overburden pressure of $150 \mathrm{kPa}$. The peak shear strength is reached at about $0.1 \mathrm{~mm}$ for clay sheared against steel, while this was more than $0.4 \mathrm{~mm}$ for both concrete-soil and soil-soil tests. This relatively quick strength equilibrium with the steel interface can be explained by the 
smoothness of the surface parallel to the shear plane as the smooth surfaces encourage the development of residual strength at small shear displacements. Although attempts were made to make the concrete plane as smooth as possible, the steel plate was considerably smoother than the concrete. The formation of orientation domains at the clay interface was found to begin at relatively small strains (Goldstein et al., 1961).

The peak and residual (nearly constant volume state) shear strength parameters obtained from the direct shear tests are summarized in Table 3.2. Both peak and residual strengths mobilized in pile-soil interface tests were smaller than those obtained from soilsoil tests. The residual shear strength for the clay sheared alone ranged from $20-60 \mathrm{kPa}$ for normal stresses ranging from $60-150 \mathrm{kPa}$. This residual strength, however, was significantly lower for the interface tests. The interface residual strengths, for the same normal stresses, were measured at $15-33 \mathrm{kPa}$ and $10-14 \mathrm{kPa}$ for both concrete-soil and steel-soil systems, respectively, with the lowest values of residual strength demonstrated by the clay sheared against steel. The relative difference between the interface strength of concrete and steel could be attributed to the smoother surface of the steel plane.

Interface strength envelopes for both the steel and concrete materials, and for the clay itself, are shown in Figure 3.6. The interface friction angles, $\delta$, obtained from linear fits to the test data are summarized in Table 3.2, in comparison with the soil friction angle. The residual friction angles for both concrete- and steel-soil interfaces were estimated at 12 and $2.5^{\circ}$, respectively. As it has been noted, the soil tested against the steel plane showed lower interface friction angle $\left(\delta_{\mathrm{r}}=2.5^{\circ}\right)$. This difference in interface strength could be explained by the orientation of clay particles along the shear zone 
(Lupini et al. 1981) due to the smoothness of the plane surface of the interfaces. The smooth surface of the steel facilitates the clay particles to be more efficiently orientated in the direction of movement than the concrete interface (Rouaiguia, 2010). The smooth interface, thus, leads to lower interface shear resistance $\left(\delta_{\mathrm{r}}=2.5^{\circ}\right)$. Negligible cohesion intercepts of less than $7 \mathrm{kPa}$ were also observed in steel-soil interface tests, while this was about zero for concrete-soil interface and negative cohesion for the soil-soil case. These low cohesion values could be related to the approach of testing used in these experiments, in which, the displaced specimen was placed back on its original position for subsequent shear test.

As discussed earlier, the residual friction angle obtained by the direct shear tests for soil-soil was found to be greater $\left(\phi_{r}=23.6^{\circ}\right)$ than that of the soil-interface tests for similar stress conditions. Correlation between the soil and the interface strength values shows the interface friction values could be much lower than those proposed in the literature (e.g., $\left.\delta=0.5-0.7 \phi_{\text {soil }}\right)$. Without taking into account the effect of capacity increase over time, the interface friction angle could be as low as $10-50 \%$ of the soil friction angle $\left(\delta=0.1-0.5 \phi_{\text {soil }}\right)$ for steel and concrete planes, for the conditions tested here. 

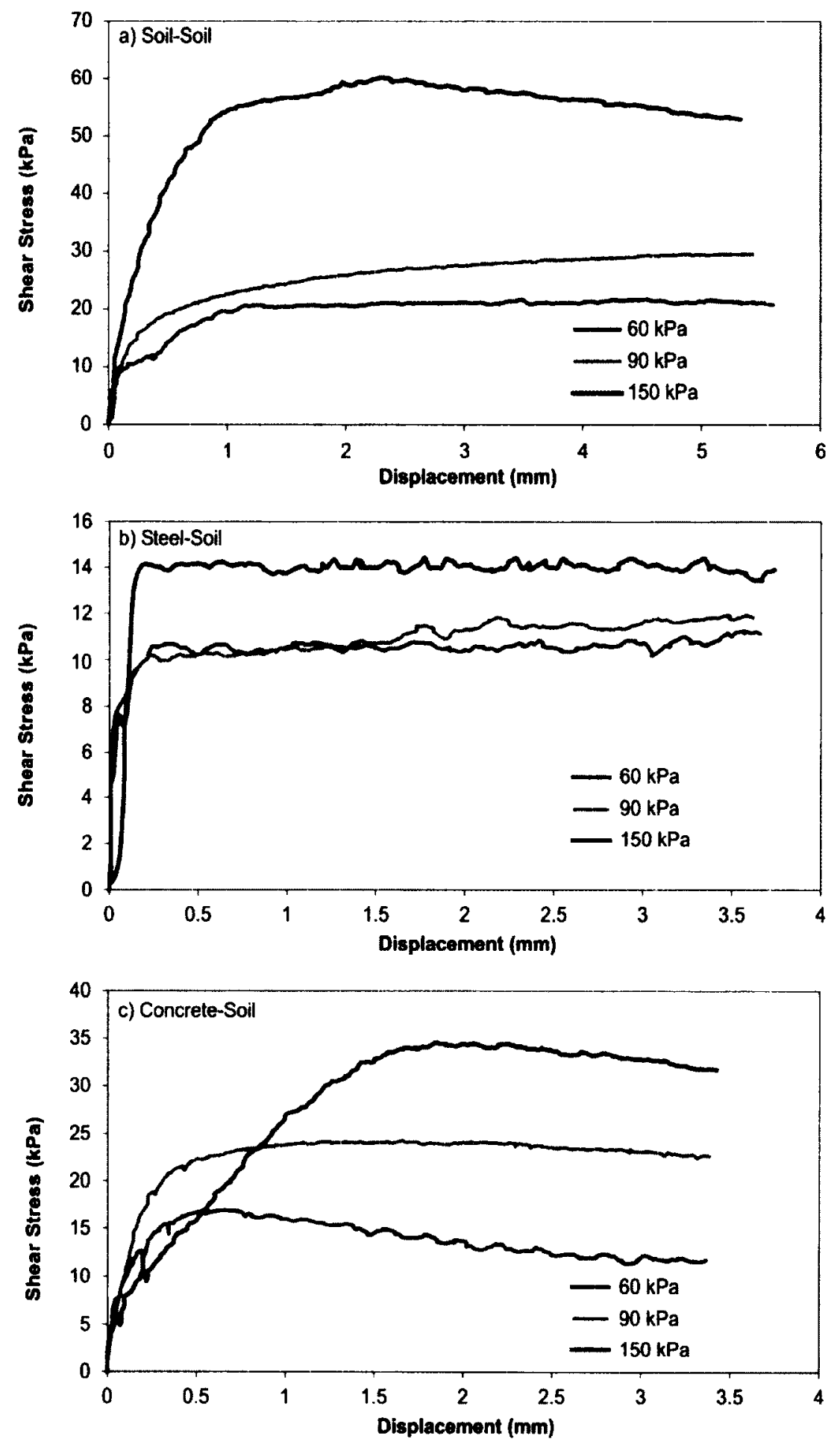

Figure 3.5: Shear stress-displacement curves for soil-soil and soil-pile shear tests; a) soil-soil, b) steel-soil, and c) concrete-soil 


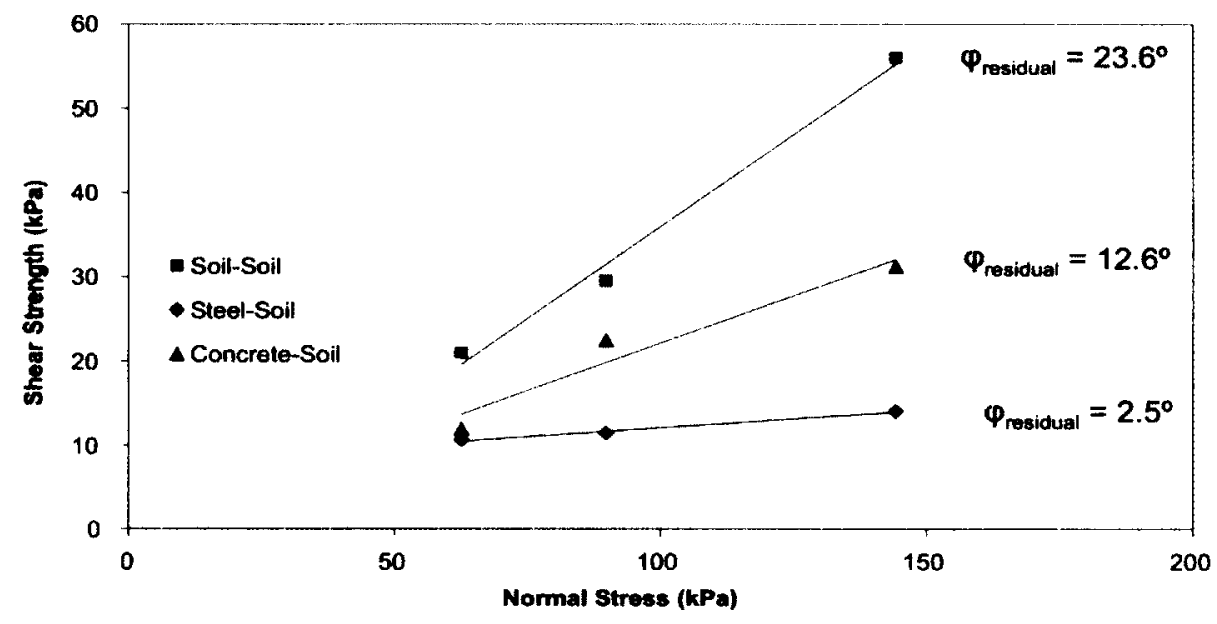

Figure 3.6: Stress envelope for soil-soil and soil-pile shear tests

\subsubsection{Evolution of pile soil interface strength with time}

Interface shear tests were also repeated 1,5 and 12 days after initial shearing to study the evolution of the interface strength with time for both steel-soil and concrete-soil systems. The resulting shear stress-displacement curves are reported in Figures 3.7a and 3.8a for steel-soil and concrete-soil systems, respectively. Both the steel- and concrete-soil specimens, which were allowed to consolidate after the initial shearing, gained strength as the consolidation time increased. For the steel-soil interface under a normal stress of $150 \mathrm{kPa}$, the residual shear stress significantly increased 12 days after the initial shearing from an initial value of $14 \mathrm{kPa}$ to $25 \mathrm{kPa}$ (Figure 3.7a). A similar trend was recorded for concrete-soil interface tests under similar confining pressures, in which the residual strength was increased from $25 \mathrm{kPa}$ initial shearing strength to about $55 \mathrm{kPa}$ for tests 
repeated 12 days after the initial shearing (Figure 3.8a). These results are in general agreement with fundamental observations on the time-dependent strength of soils which is related, at least in part, to the dissipation of excess pore water pressure in the interface zone. After initial shearing, excess pore pressures in the soil near the interface zone begin to dissipate. As pore pressures dissipates, the effective stress increases, and the soil around the shear zone consolidates and gains strength

Although dissipation of excess pore pressure contributes to the time dependent strength increase, it is not the only mechanism responsible for the time effects. Karlsrud and Haugen (1991) presented data showing that the pile still gained capacity after excess pore pressures were completely dissipated. These observations indicate that changes in interface strength, and hence pile capacity, are not completely explained by the effects of pore pressure. Schmertmann (1991) attributed increase in strength to mechanical effects such as increase in soil friction, or change in effective stress with time. Axelsson (1998) reported ageing as one of the factors that can increase soil strength by increasing the stiffness of the soil and reducing its compressibility. Stress independent phenomena, such as strength increase due to thixotropic bonding, have also been reported as controlling mechanisms of the capacity increase in piles (e.g., Svinkin and Skov, 2000). 

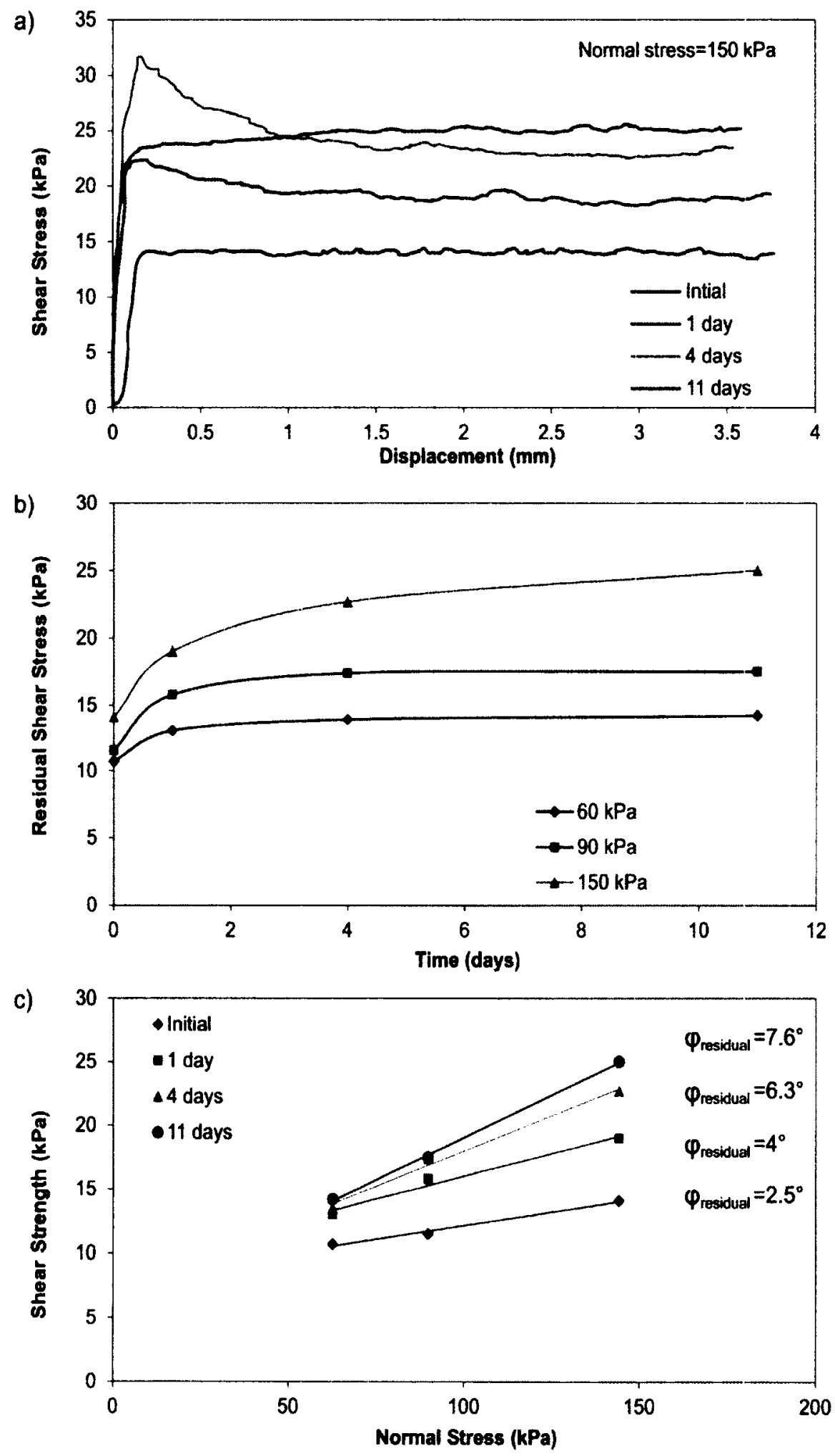

Figure 3.7: Increase in interface strength of steel-soil system 


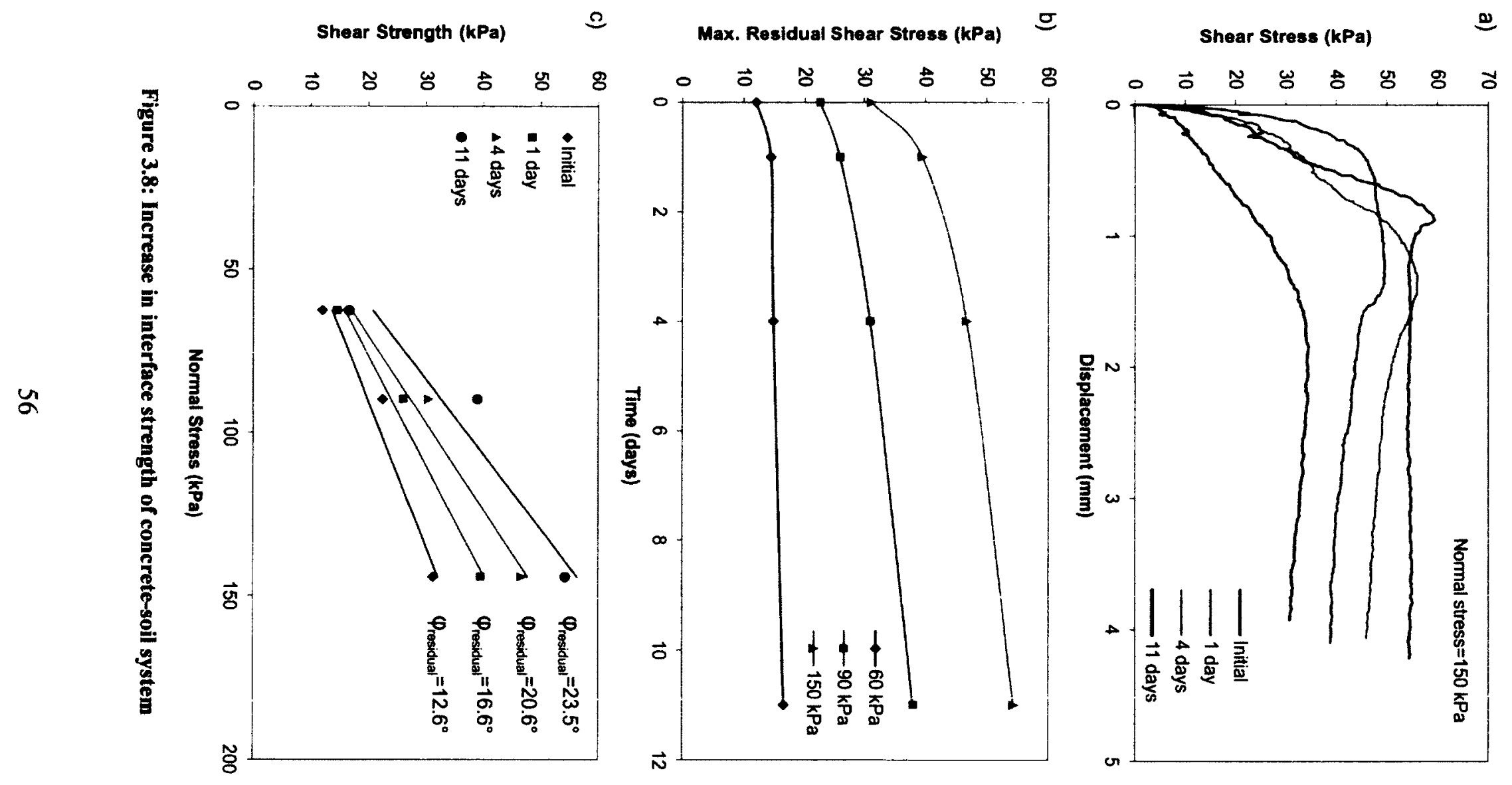


The variation of the strength with time is shown in Fig. 3.6b and 3.7b for both steel- and concrete-soil interfaces, respectively. As noted, the rate of strength increase has been shown to decrease as consolidation time increases. This rate is much higher in earlier stages, showing a significant increase for interface tests performed one day after the initial shearing but the difference between the residual shear strength for tests performed 5 and 12 days after initial shearing was negligible. This could be related to faster dissipation of excess pore water pressure and a higher rate of consolidation of the soil in earlier stages. Terzaghi's theory for one-dimensional consolidation can be used as an approximation to predict the dissipation of excess pore pressure at the interface:

$$
\mathrm{T}=\mathrm{t} / \mathrm{t}_{100}=\mathrm{C}_{\mathrm{v}} \mathrm{t} / \mathrm{H}_{\mathrm{dr}}{ }^{2}
$$

where $T$ is the time factor, $t_{100}$ is the time of the complete consolidation. $t$ is the time of consolidation, $c_{h}$ is the horizontal coefficient of consolidation and $H_{d r}$ is the length of the drainage path perpendicular to the pile axes.

The drainage length can be assumed to be the width of the remoulded zone around the pile, or even as low as half the remoulded width for the case of concrete piles where pore water may flow from the remoulded zone into both the surrounding soil and the pile itself.

This remoulded length for the pile-soil system can be obtained from the theory of cavity expansion in elasto-plastic media. By knowing the undrained shear strength and the shear modulus of the soil, the distribution of initial excess pore water pressure outward the pile can be predicted (Randolph et al., 1979). The excess pore pressure varies along the remoulded zone, showing a maximum at the pile surface and zero at $H_{d r}$ (Leifer 
et al., 1979). Using this expression, the time required for the remoulded zone to consolidate can be estimated assuming the excess pore water pressure is uniformly distributed within the remoulded area. For example, in a $0.5 \mathrm{~m}$ concrete pile driven into Winnipeg clay (Table 3.1) the remoulded zone around the pile would take about 15 days to consolidate.

The results can also be interpreted by means of the interface friction angle $(\delta)$. As noted, $\delta$ is analogous to the interface friction used in the effective stress approach for evaluating lateral friction in piles. The interface friction angles were estimated for each test based on the stress envelope for three different normal stresses (Figures 3.7c, 3.8c). As it can be seen, the interface friction angle for the steel-soil system increased from an initial value of $2.5^{\circ}$ to about $7.6^{\circ}$ after 12 days of consolidation. In the case of the concrete-soil interface, the initial friction angle of $12.6^{\circ}$ increased to $23.5^{\circ}$ after 12 days of consolidation. Considering this time-dependent strength increase, the ratio between the interface friction angle, $\delta$, and the friction angle of the soil will be approximately 0.32 and 1.0 for the steel- and concrete-soil systems, respectively $(\delta=0.32-1.0 \phi)$. These ratios correspond to a consolidation degree of about $100 \%$ for both the steel and concrete interface systems. Values of the interface friction angle for piles driven into the soft Winnipeg clays are generally taken to be 0.5 to $0.7 \times \phi_{\text {soil }}$, which agrees with the experimental data presented however, it is still slightly higher than what is achieved in this study for the steel-soil system. 


\subsubsection{Effect of pile materials on time dependent interface strength}

Pile capacity increase has been documented for virtually all driven pile types (wood piles, H-piles, pipe piles, tapered steel piles, fluted steel piles, and pre-stressed concrete piles). A study by Finno et al. (1989) reported that a pipe pile generated higher excess pore water pressures during installation than an H-pile did. Conversely, the unit shaft resistances for the two mentioned piles were approximately equal after 43 weeks. Prestressed concrete piles generally showed more capacity increase than steel piles (Preim et al., 1989). This phenomenon has been attributed to a higher soil-pile interface coefficient of friction. To investigate the effect of pile materials on interface strength increase residual shear stress-elapsed time curves for both interface systems were normalized by dividing the maximum shear stress in different elapsed time to that of the initial shear tests (Figure 3.9). Although the specific strength values for concrete pile are higher than those measured for the steel piles, similar rates of strength increase were observed for both steel and concrete surfaces. It should be noted that change in pore-water salt concentration may also affect the interface strength, especially for the case of concretesoil, through cation exchange phenomenon.

Increase in interface strength is also depended on the level of normal stress at the pile-soil interface (Figure 3.9). Under an imposed overburden pressure of $60 \mathrm{kPa}$, the normalized shear strength was found to be about 1.35 for both interface systems, after 12 days of consolidation. This ratio, however, was about 1.7 for both interfaces with an overburden pressure of $150 \mathrm{kPa}$ under otherwise similar conditions. 


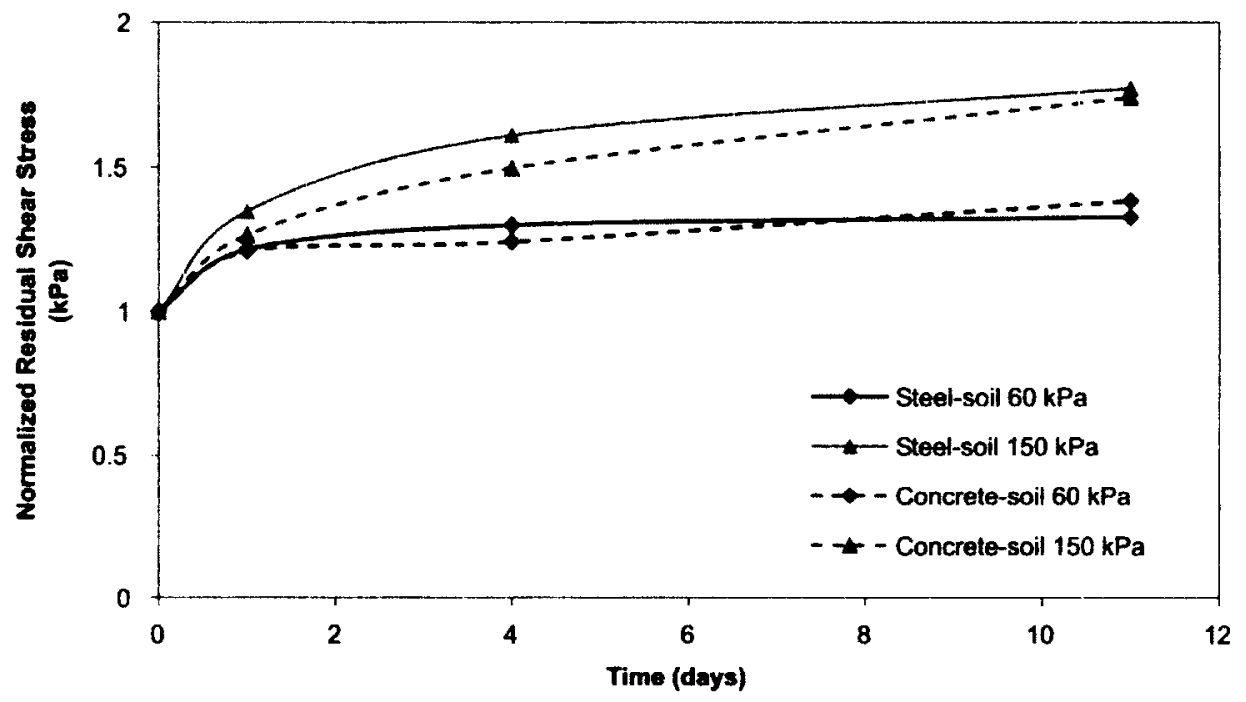

Figure 3.9: Comparison of measured increase in interface strength of concrete-soil with steel-soil systems

\subsubsection{Comparison with results of pile load test in the field}

The evolution of strength with time was compared with those achieved during the large scale pile load tests in the field (Winnipeg, Canada). The pile-load test was performed on a $38 \mathrm{~m}$ open end steel pipe pile with outside diameter of 610 millimeters approximately two weeks after the initial driving to estimate the time-dependent variations in load capacity. Pile capacity at the end of driving and restrike was measured by utilizing Pile Driving Analyzer (ASTM D-4945). The data to identify the time-dependent changes in pile capacity was reported as a ratio of capacity at a given time $\left(Q_{t}=1,988 \mathrm{kN}\right)$ to the capacity of the pile at the end of driving $\left(Q_{0}=3,925 \mathrm{kN}\right)$. The axial capacity measured two weeks after driving showed a value twice its original capacity $\left(Q_{1} / Q_{0}=2.0\right)$, which 
corresponds to a consolidation degree of $93 \%$. A slightly different trend was achieved for the steel-soil interface tests in direct shear apparatus, in which the initial interface friction angle of $2.5^{\circ}$ increased to $7.6^{\circ}$ for tests performed 12 days after the initial shearing $\left(\delta / \delta_{0}=\right.$ 3.04). This could be related to the difference in rate of loading between the laboratory and the field tests as well as variation in soil profile with depth in the field.

\subsection{Summary}

An experimental program was employed to investigate the evolution of pile-soil interface strength over time using a modified direct shear test apparatus for both concrete- and steel-soil systems. Comparison of shear stress-displacements for soil-soil and pile-soil interface tests revealed a relatively small displacement of the pile is required to reach the ultimate interface strength under tested conditions. The interface strength obtained by the direct shear tests for pile-soil specimens was found to be less than those of soil-soil tests. The residual friction angle for the steel-soil interface was much lower than that of the concrete-soil tests, showing values as low as $10 \%$ of what was measured for soil under similar conditions. This was attributed to the smooth surface of the steel plate, against which the soil particles have attained their maximum degree of orientation leading to the minimum possible resistance to shear $\left(\delta_{\mathrm{r}}=2.5^{\circ}\right)$.

The interface strength for both concrete- and steel-soil systems increased as the consolidation time after the initial shear tests increased up to 12 days. The maximum increase in interface strength varied from $20-80 \%$ of the initial shear strength, depend on the normal stresses applied. These results are in general agreement with fundamental 
observations on the time-dependent strength of soils which is related, at least in part, to dissipation of excess pore water pressure in the interface zone. The rate of strength increase was shown to be similar in both steel and concrete surfaces, although the specific strength values for concrete piles are higher than those measured in steel piles.

Considering this time-dependent strength increase, the ratio between the interface friction angle, $\delta$, and the friction angle of the soil is shown to be about 0.32 and 1.0 for the steel- and concrete-soil systems, respectively $(\delta=0.3-1.0 \phi)$. Values of the interface friction angle for piles driven into soft Winnipeg clays are generally estimated to be 0.5 to $0.7 \times \phi_{\text {soil }}$, which generally agrees with the experimental data presented here, although it is still slightly higher than what achieved in this study for the steel-soil system. 


\section{CHAPTER :4 PILE SETUP EVALUATION IN LEDA CLAY, OTTAWA, ON}

\subsection{Overview}

Pile setup magnitude may influence the pile design and lead it to a more economical foundation system with utilizing lighter material and consequently retaining less manpower. In industry, to determine an optimum and safe magnitude prediction of pile setup, a system of load testing on selected test piles is considered which is expensive and time consuming. The experimental program discussed in this chapter tends to propose a reasonable pile setup prediction, based on performing a medium scale pile testing in laboratory condition. Leda clay was used as the soil system in this experiment. This soil is a type of sensitive marine clay formed 10,000 years ago in a salty marine environment. Leda clay is mostly found where Champlain Sea existed and is the area of current eastern Ontario and Quebec (Figure 4.1).

The resistance against vertical movement on friction piles is mainly provided by interface shear strength between pile and soil. In Chapter 3, interface shear strength between the pile materials and the soil was investigated using direct shear apparatus. As further stage to simulate a homologous situation of test piles in industry scale, medium scale pile load testing was conducted to study pile setup behaviour for driven pile in Leda clay. The experimental setting for pile load testing includes a number of essential 
components such as soil sample, source of load application, source of reaction and measurement devices.

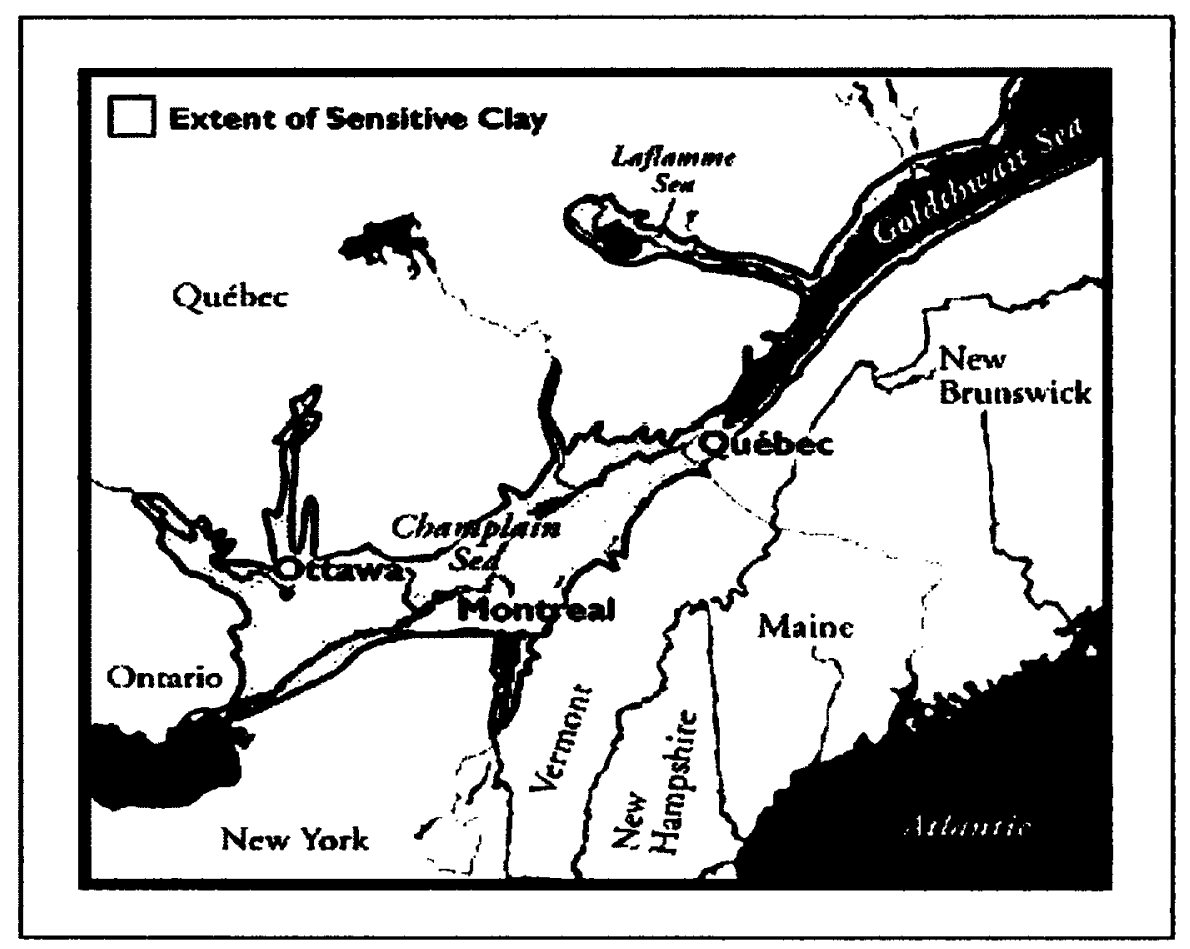

Figure 4.1: Extent of Leda clay in Ottawa and St. Lawrence River lowlands (In courtesy of CMHC)

\subsection{Obtaining Leda clay sample}

Large-scale samples of Leda clay were obtained from a site in Navan area in east of Ottawa, ON. To obtain the undisturbed clay samples, twelve $600 \mathrm{~mm}$ diameter and $900 \mathrm{~mm}$ height barrels were utilized. An excavator was used to push the barrel very slowly into the clay bed. During driving, a series of small holes were made at the bottom of the barrels as air vents to release the air stuck between the soil and the bottom of barrel. Figure 4.2 presents a photo of the barrels and the drilled vent holes. 


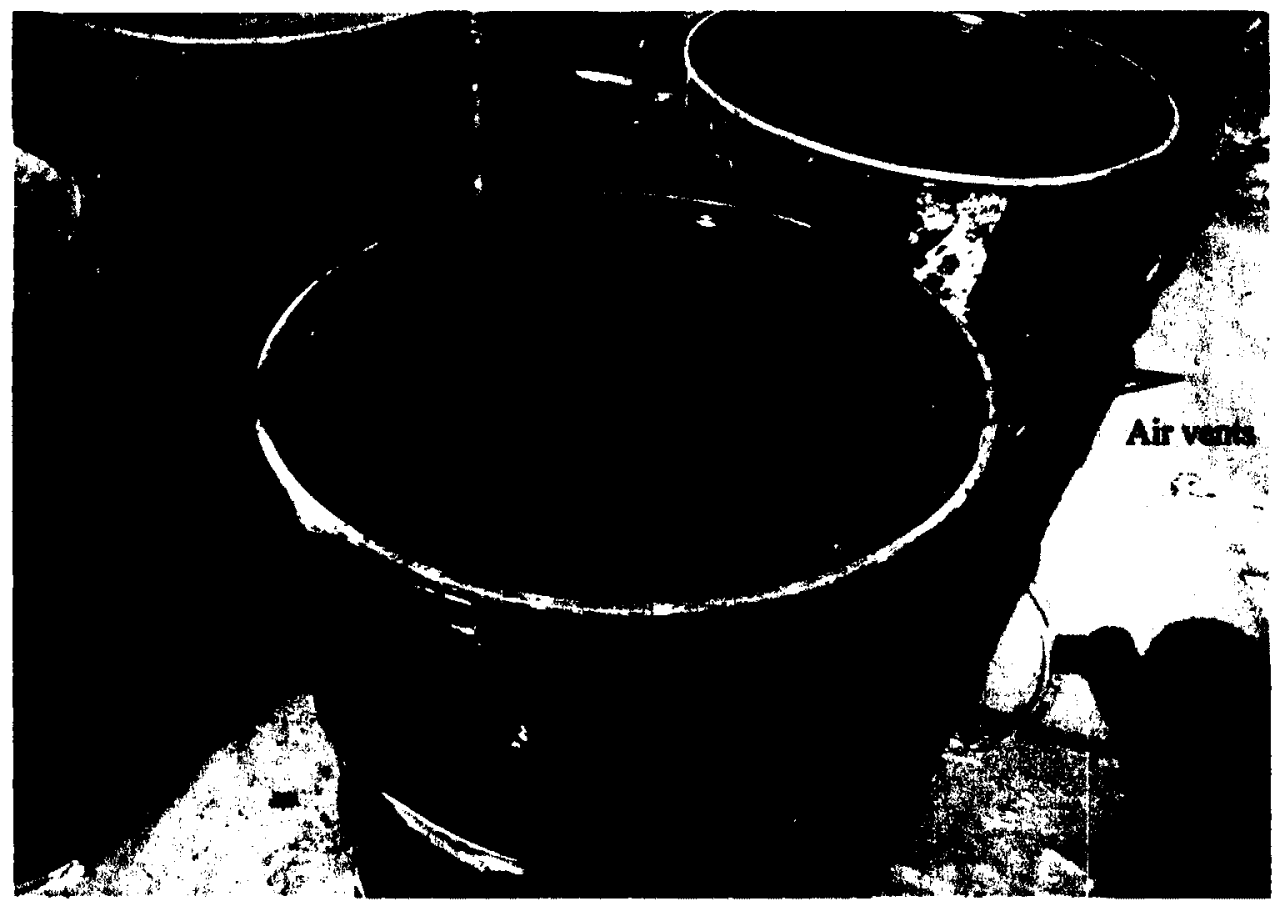

Figure 4.2: Holes provided at the bottom of the barrel as air vent

The barrels were placed upside down on the surface of the soil and gently pushed into the clay bed, and then they were flipped over and released. Figure 4.3 illustrates the barrels placed on the clay and Figure 4.4 presents the barrels while they are being pressed into the clay. After the barrels were filled with undisturbed clay (Figure 4.5), they were cleaned, capped and sealed as shown in Figure 4.7 and shipped to the Geotechnical laboratory of the Carlton University, Ottawa, ON. 


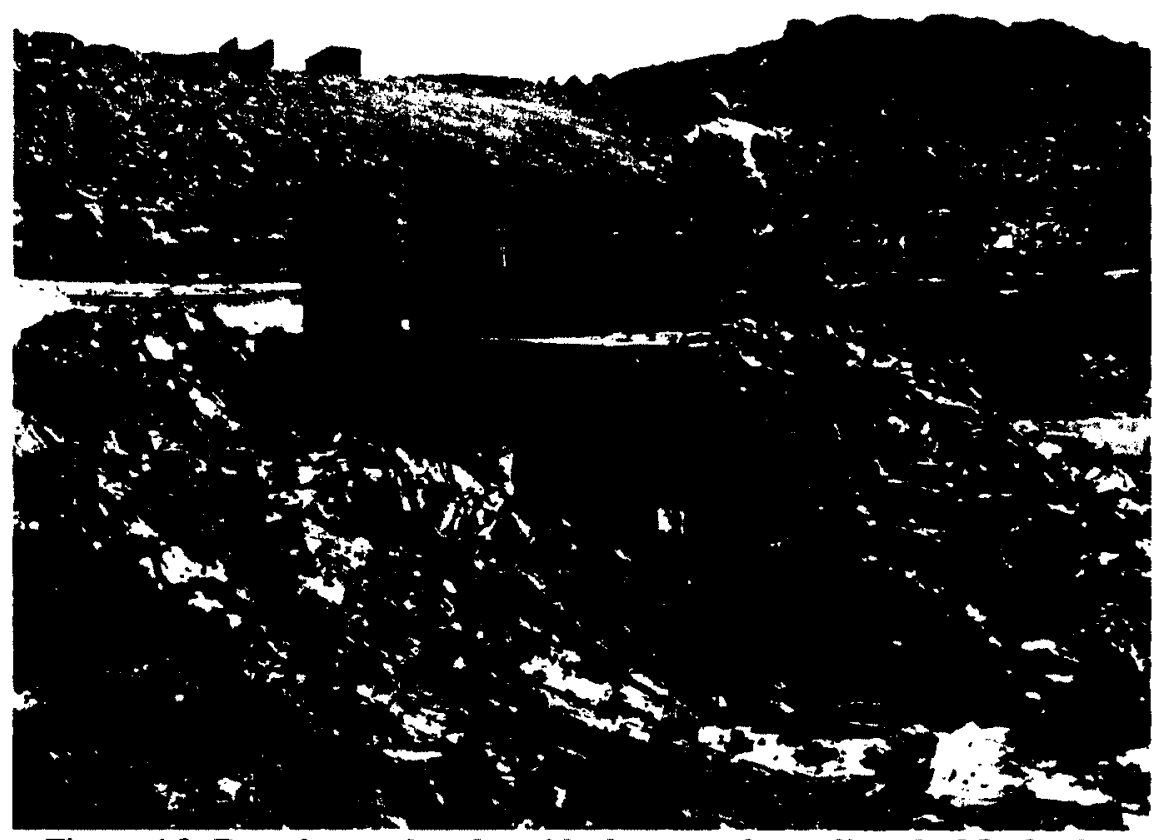

Figure 4.3: Barrels are placed upside down on the undisturbed Leda clay

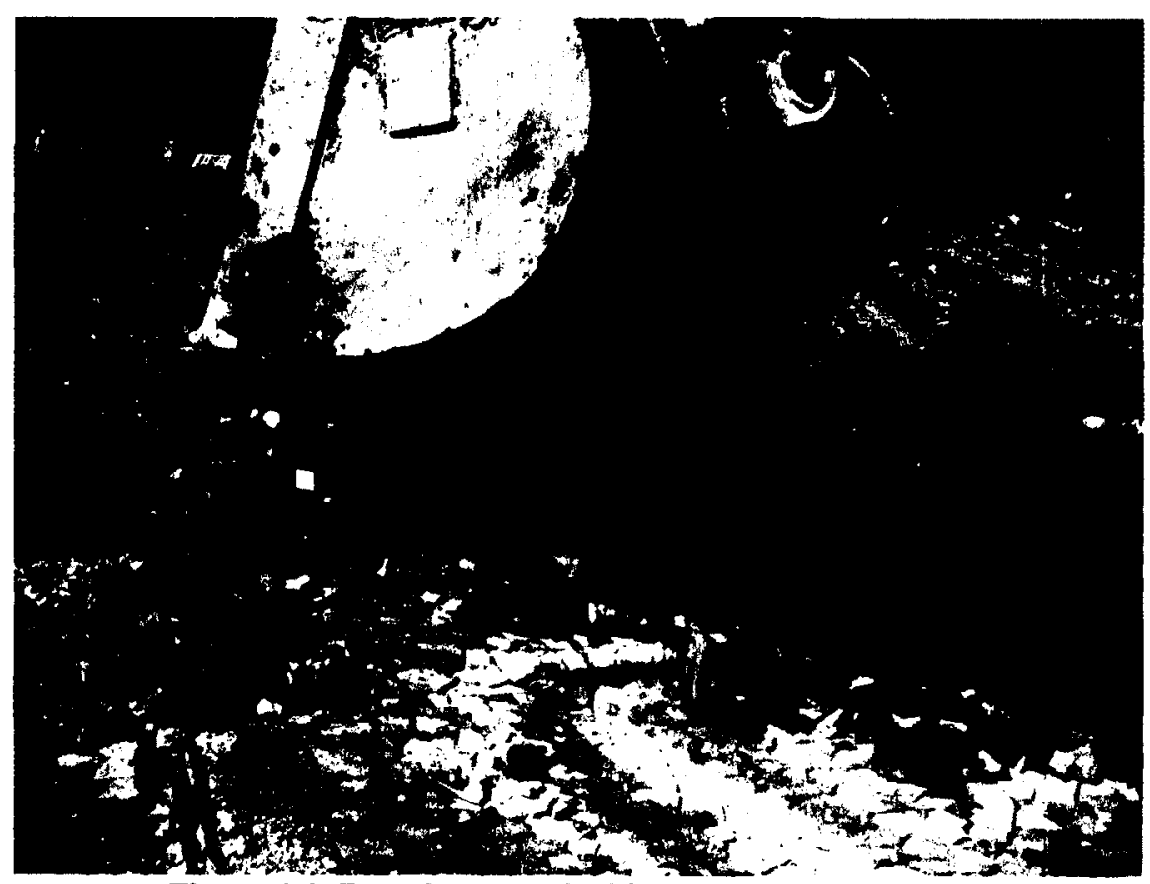

Figure 4.4: Barrels are pushed into the clay, very slowly 


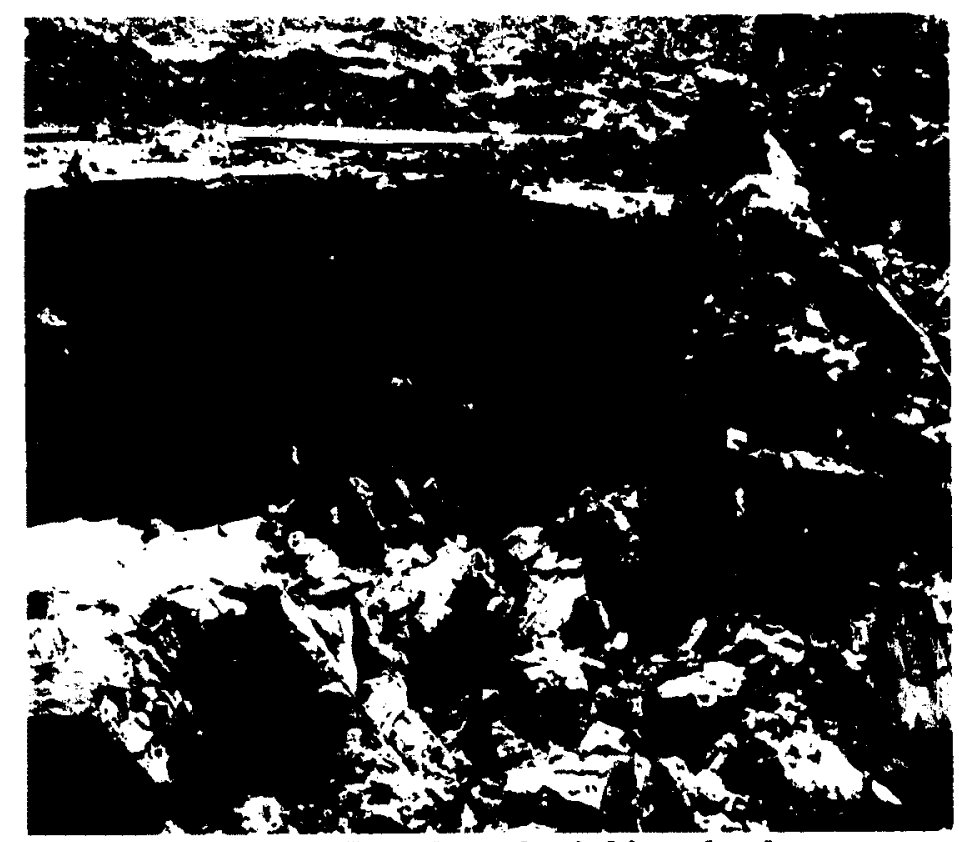

Figure 4.5: Barrels are buried into the clay

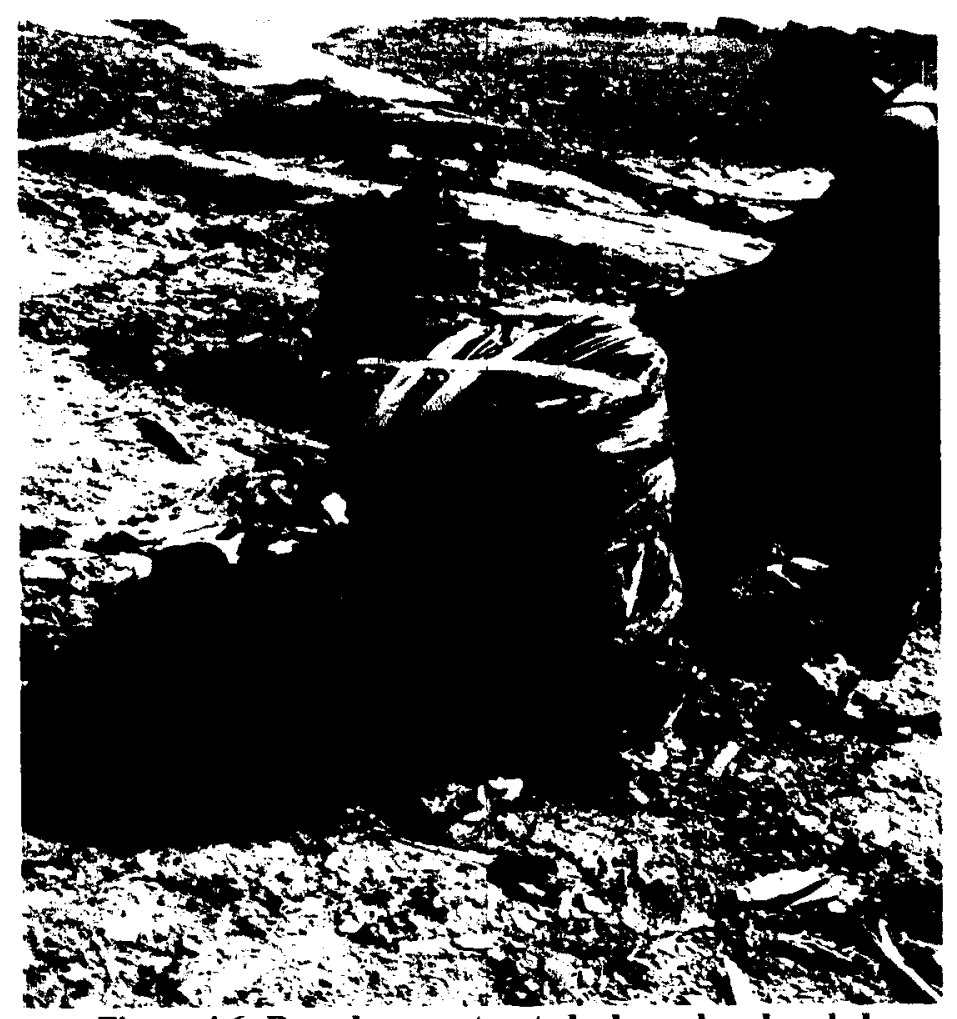

Figure 4.6: Barrels are extracted, cleaned and sealed 


\subsection{Material properties}

\subsubsection{Leda clay properties}

A series of index tests including hydrometer analyses, Atterberg, compaction and in-situ vane shear tests were conducted on the soil to determine its index properties. The average bulk density of the soil was estimated at $1.53 \mathrm{Mg} / \mathrm{m}^{3}$ with initial moisture content of about $67 \%$ (ASTM D2216) The particle size distribution of this soil, obtained from a hydrometer test (ASTM D422), shows a clay fraction of about $40 \%$ (Figure 4.7 ). The plasticity index of the soil was measured at about $23 \%$ as per ASTM D4318. The soil is classified as CL in the USCS classification system (ASTM D2487). The coefficient of consolidation of the soil obtained from 1-D consolidation test (ASTM D2435) showed a value of $1.4 \times 10^{-4} \mathrm{~cm}^{2} / \mathrm{s}$. Vane shear tests (ASTM D2573) showed an average undrained shear strength of $50 \mathrm{kPa}$ and remolded undrained shear strength of $8.0 \mathrm{kPa}$. Soil sensitivity of 6.25 was calculated which describes the soil as low sensitive clay. Using the standard proctor test (ASTM D698), the maximum dry density of the soil was measured as $1.43 \mathrm{Mg} / \mathrm{m}^{3}$ at an optimum moisture content of $28 \%$. Table 4.1 summarizes the index properties of Leda clay used in this study.

Table 4.1: Index properties of soil samples, Leda clay, Navan, ON

\begin{tabular}{ccccccccc}
\hline $\begin{array}{c}\rho \\
\left(\mathbf{M g} / \mathbf{m}^{3}\right)\end{array}$ & $\begin{array}{c}w \\
(\%)\end{array}$ & $\begin{array}{c}\mathbf{L L} \\
(\%)\end{array}$ & $\begin{array}{c}\mathbf{P I} \\
(\%)\end{array}$ & $\begin{array}{c}w_{\text {opt }} \\
(\%)\end{array}$ & $\begin{array}{c}\rho_{d(\max )} \\
\left(\mathbf{M g} / \mathbf{m}^{3}\right)\end{array}$ & $\begin{array}{c}C_{v} \\
\left(\mathrm{~cm}^{2} / \mathbf{s}\right)\end{array}$ & $\begin{array}{c}s_{u} \\
(\mathbf{k P a})\end{array}$ & $\begin{array}{c}s_{u r} \\
(\mathrm{kPa})\end{array}$ \\
\hline 1.53 & 67 & 50 & 23 & 28 & 1.43 & $1.4 \times 10^{-4}$ & 50 & 8 \\
\hline
\end{tabular}

$\rho=$ density; $w=$ moisture content; $w_{\text {opt }}=$ optimum moisture content; $\rho_{d(\text { max })}=$ maximum dry density; $c_{v}=$ coefficient of consolidation; $s_{u}=$ undrained shear strength, $s_{u r}=$ remolded undrained shear strength 


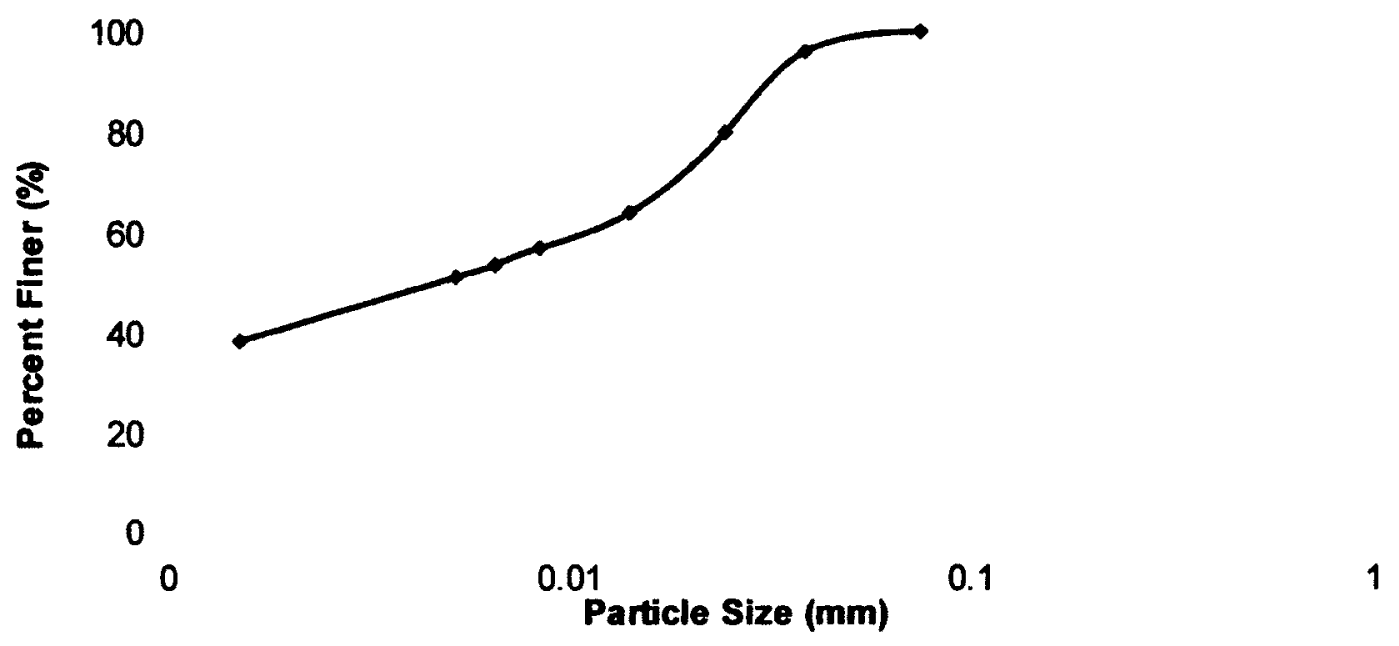

Figure 4.7: Grain size distribution of Leda Clay, Navan, ON

\subsubsection{Pile materials}

Three major types of material are used for piles in industry including Timber, Steel and Concrete. This study focuses on the steel and concrete piles as timber piles are not used very often. The concrete pile contained sand and fine-grained gravel aggregates, which are commonly used in the pile industry for making piles. A piece of $10 \mathrm{M}$ steel rebar was placed in the middle of the concrete pile to distribute the applied load within whole shaft area and facilitate the load tests. A special very fine cement mortar was used as concrete cement to trace same surface texture of large scale concrete pile in industry. Both the steel and concrete piles used in these experiments had fairly smooth surfaces, with no roughness apparent on either surfaces. Figure 4.8 presents a photo of the precast concrete pile and the steel pipe pile. 


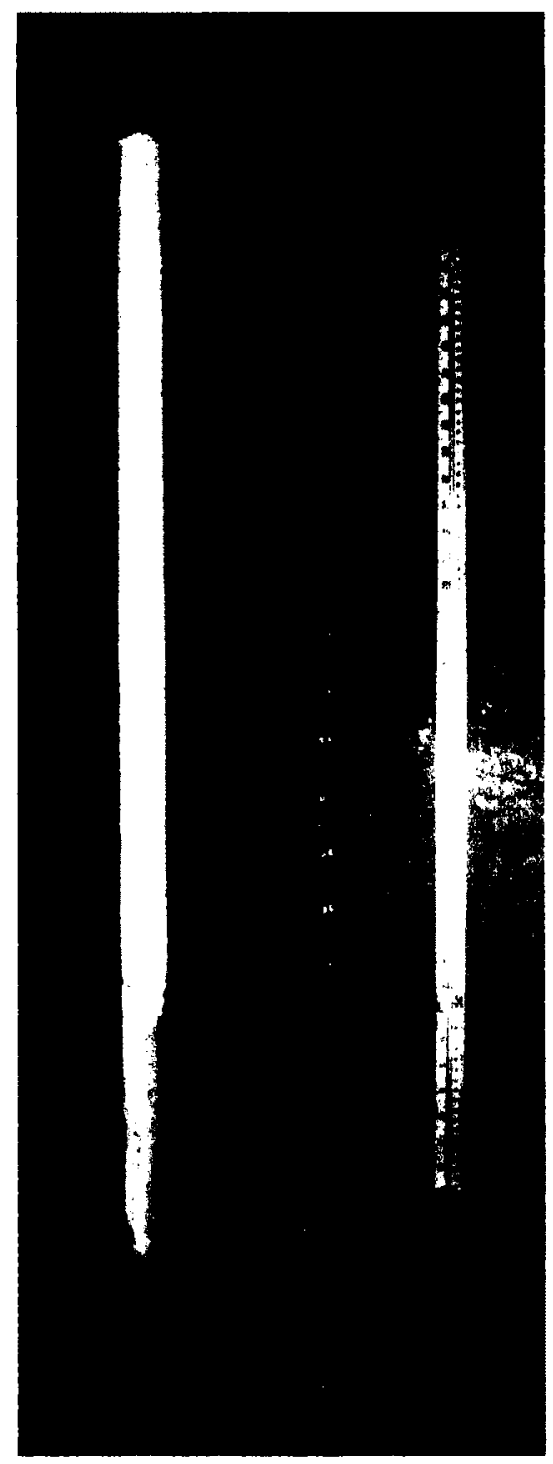

Figure 4.8: 48mm diameter precast concrete pile and steel pipe pile

\subsubsection{Boundary condition}

The main obstacle in scaled load testing is stress-strain compatibility. The impediment is caused by the difference in pile size, depth and material strength. Piles in scaled load testing program are relatively extended to a shallower depth, thus result of these types of 
testing should be adjusted or reduced accordingly for prototype testing (Altaee et al., 1994; Laefer, 2001; Ko et al., 1984; Yan et. al, 1989 and Zelikson, 1969). The other effective parameter in small scaling would be the pile size. As mentioned earlier, the generated excess pore water pressure and stress change are transmitted in a radical path from pile to the adjacent soil up to three times the pile diameter.

In this experiment, test piles with an outside diameter of $48 \mathrm{~mm}$ were employed, thus the pore water pressure and stress change in clay can be observed within the pile surrounding soil from the pile surface up to a distance of $144 \mathrm{~mm}(3 \times 48 \mathrm{~mm})$. These measurements allocate a minimum effective cylindrical area with diameter of $336 \mathrm{~mm}$ $(=2 \times 144 \mathrm{~mm}+48 \mathrm{~mm})$. As mentioned earlier, Leda clay samples were extracted using $600 \mathrm{~mm}$ diameter and $900 \mathrm{~mm}$ height barrels. To prove that the boundary condition for the test-pile and soil-sample size selections is appropriate, a numerical analysis was performed using Sigma/W (Geo-Studio 2007).

Analyses were utilized based on 2-Dimensional modelling. The soil was modelled as a linear elastic material and pile was modelled as a structural element. The analyses were initially performed as in-situ state to stabilize the normal stresses in the system. A tension load of $3.0 \mathrm{kN}$ was then applied to the pile, and the lateral pressure and vertical movements were monitored for each trial. Results indicated that a pile with $48 \mathrm{~mm}$ diameter and $600 \mathrm{~mm}$ driving length provides negligible lateral pressure on the container. Piles need to be driven into the barrel with minimum of $200 \mathrm{~mm}$ clear distance to the barrel tip to avoid any change in stress underneath of pile tip. Figure 4.9 illustrates the numerical analysis schematic of pile test, using Sigma/W 2007. Input report of the 
analyses is presented in Appendix A. Based on numerical analysis, $48 \mathrm{~mm}$ outside diameter pile and $600 \mathrm{~mm}$ diameter soil sample barrel provide sufficient geometry for the experiment as a medium scale pile load test.

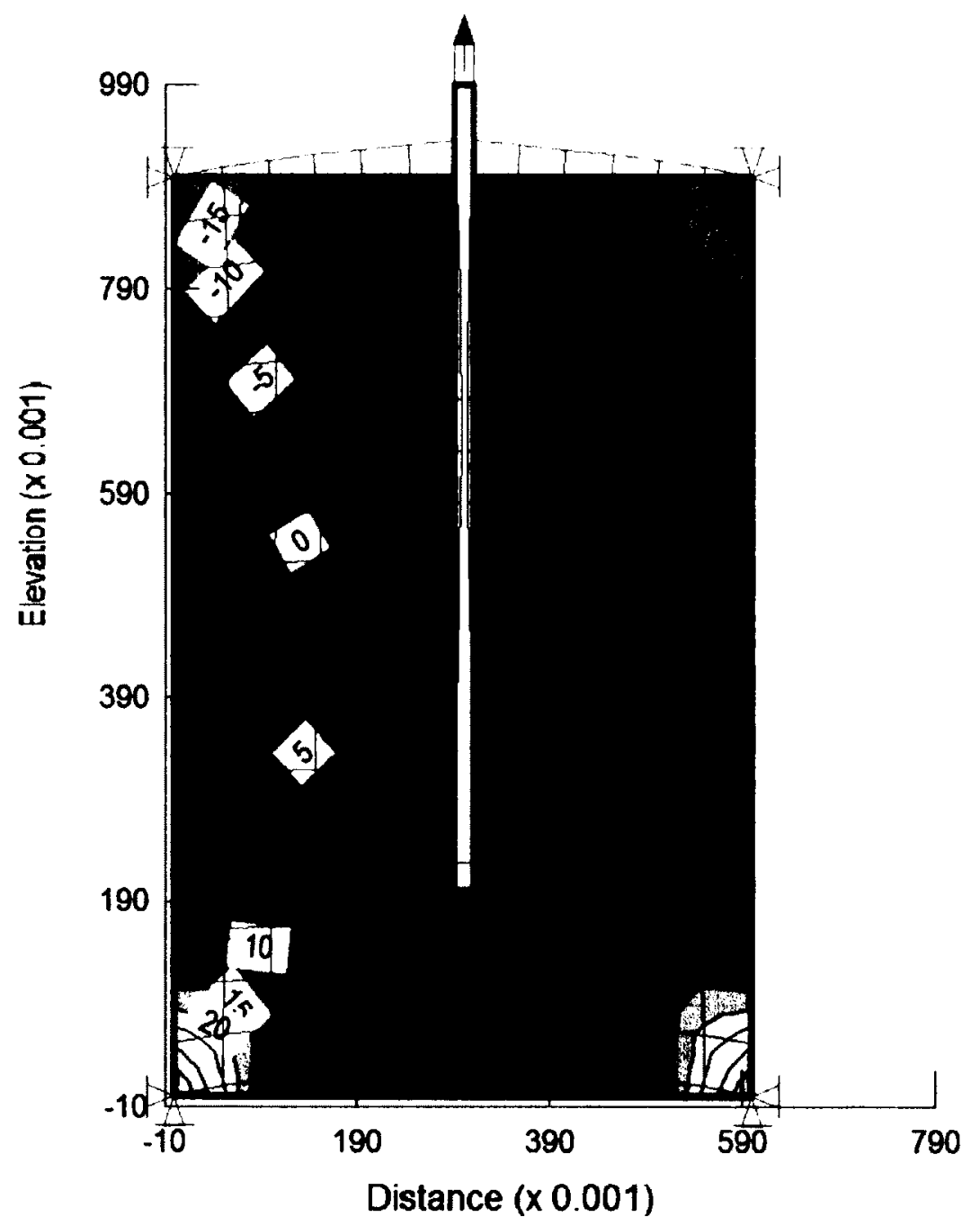

Figure 4.9: Numerical analysis model of driven pile in Leda clay barrel, numbers represent variations in stress distribution in kPa (Sigma/W 2007) 


\subsection{Experimental Program}

\subsubsection{Test frame design}

Exploiting reaction frame for static test is widely used in industry to determine the pile capacity, especially when there is a need to apply the load in both directions of downward or compression and upward or tension. Reaction frame should be designed to provide the required strength against applied load with reasonable factor of safety and with acceptable deflection. The resistance force in most cases is provided by using reaction piles or weights. In general, the load test setup requires a source of loading, such as hydraulic jack, a load measuring device, such as load cell, and displacement measuring devices such as LVTD or digital indicator.

A testing setup plan was proposed to provide all above mentioned components. Steel $\mathrm{H}$ sections were used as a reaction beam and columns. The columns were bolted and secured to the thick concrete slab to provide required reaction resistance. A Hydraulic jack was employed as a source of load and a recently calibrated load cell was used for load measurement. Two $200 \mathrm{~mm}$ deep lumber beam were used as reference beams to install displacement measuring devices. Two digital indicators were also utilized to measure pile head and soil surface displacement. Figure 4.10 presents a schematic view of the reaction frame and test setting.

Figure 4.11 presents the load test setup to utilize the compression and tension loading on test piles. Each barrel was placed and secured on a very stiff pallet to minimize the movement and deformation barrels during testing. Frame height is sufficient to provide enough space to drive and test the piles into the soil within barrels. 
Reaction beam was consisted of two C-Channel steel profiles, connected together using a $25 \mathrm{~mm}$ thick plate which is used as a base for source of load application (Hydraulic jack). The pile load is transferred from hydraulic jack to the pile head plate using an all threaded rod. Reference beams are to provide a base for lateral restriction plates and also a base for digital movement indicators. A station table was provided to have all monitoring and processing equipment installed, including a data logger connected to the load cell, a computer connected to the data logger and piezometer and Pile Dynamic Analyzer (PDA).

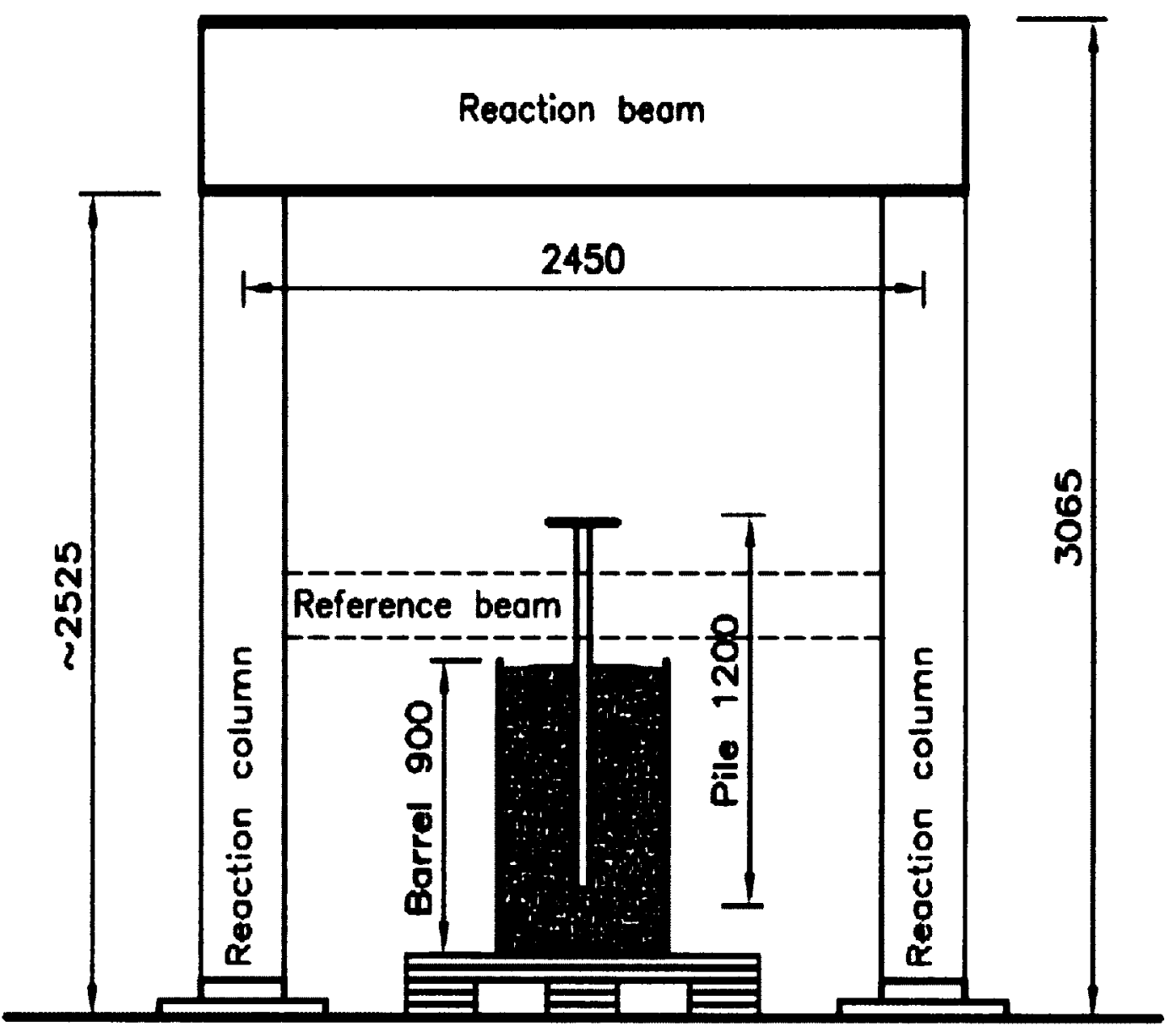

Figure 4.10: Static load test frame illustration 


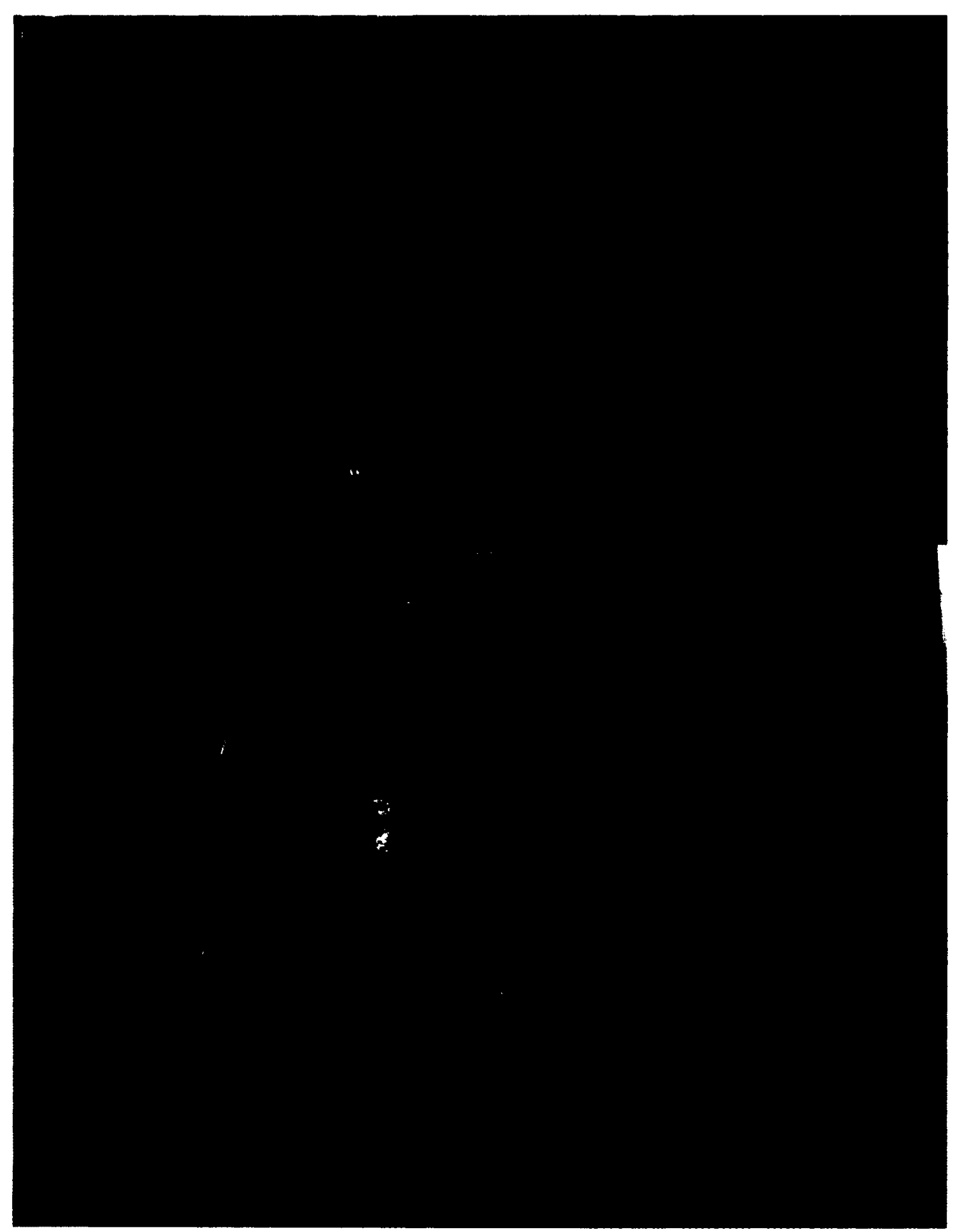

Figure 4.11: Load test frame 
One of the main concerns while pile is advanced into the soil is the pile alignment. To ensure a proper alignment, two pieces of plywood were used to cut in specific shape as shown in Figure 4.12 to hold the pile in vertical position during driving. The holding pieces were placed and secured on reference beams in a manner to have the pile restricted from lateral movement on horizontal plane. A piece of square steel plate with four holes was also designed to be welded to the pile head as shown in Figure 4.13. This pile cap was used to connect the pile to the loading device as well as for displacement measurement.

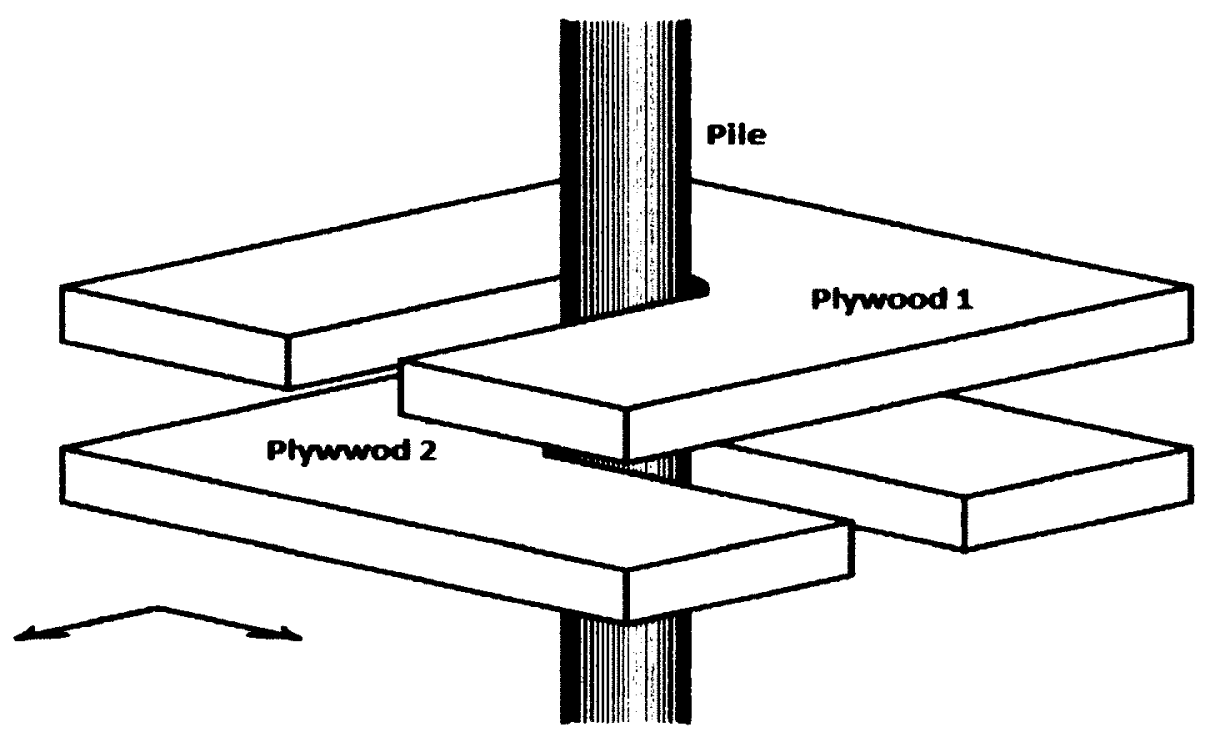

Figure 4.12: Vertical support mechanism: Two pieces of plywood restrain pile from lateral movement 


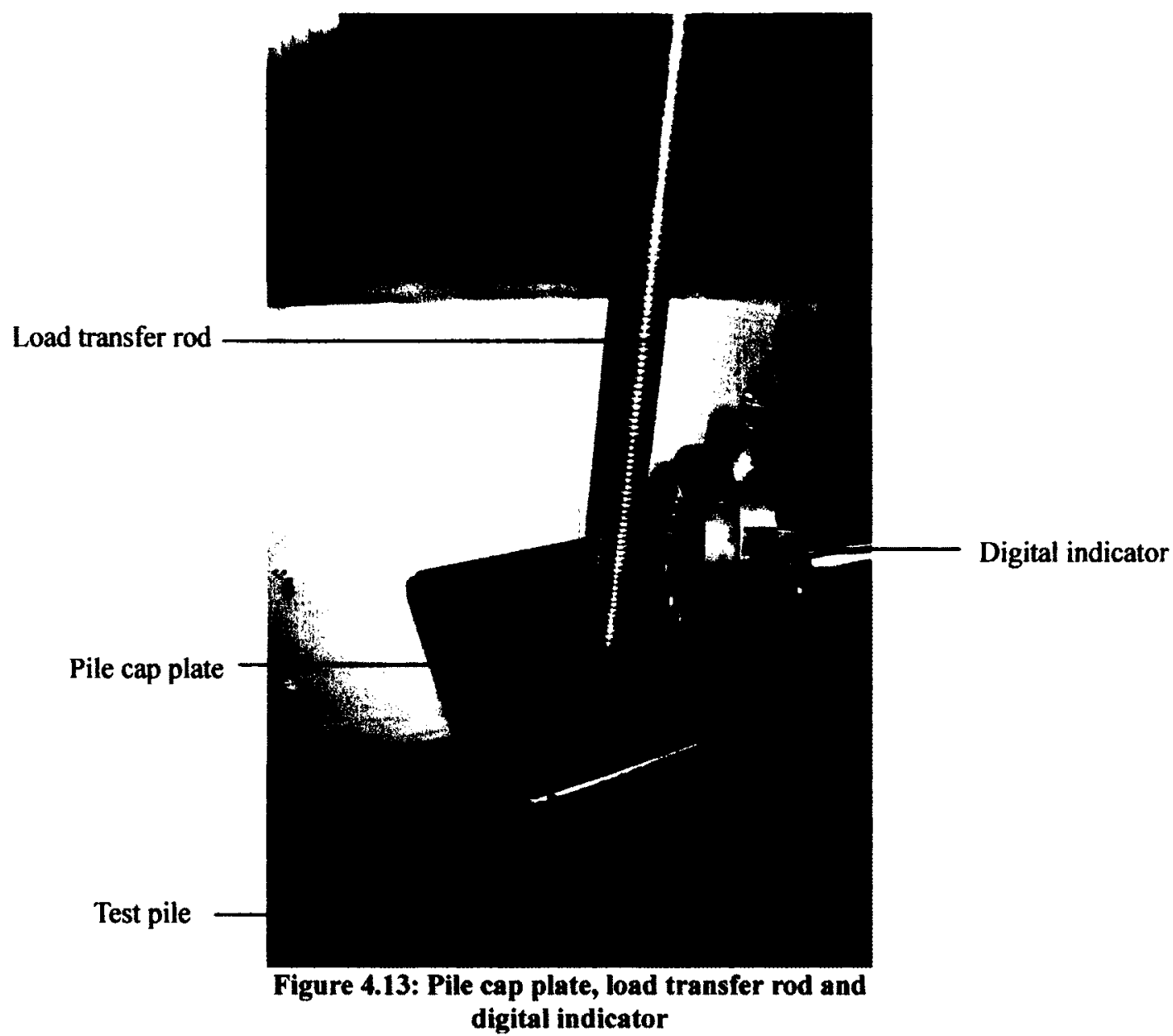

\subsubsection{Pile driving techniques}

Dynamic loading is mainly used to drive piles in industry using drop, diesel or hydraulic hammers where a specific weight is dropped at a certain height. Both weight and height can be controlled to maintain a desired load or transferred energy to the pile head to control stress as well as penetration resistance (PRES). In this experiment, a similar concept has been utilized by dropping specific weights at certain height. As shown in Figure 4.14, a steel block is elevated to a desired height through a guide bar and dropped on the pile head plate. 


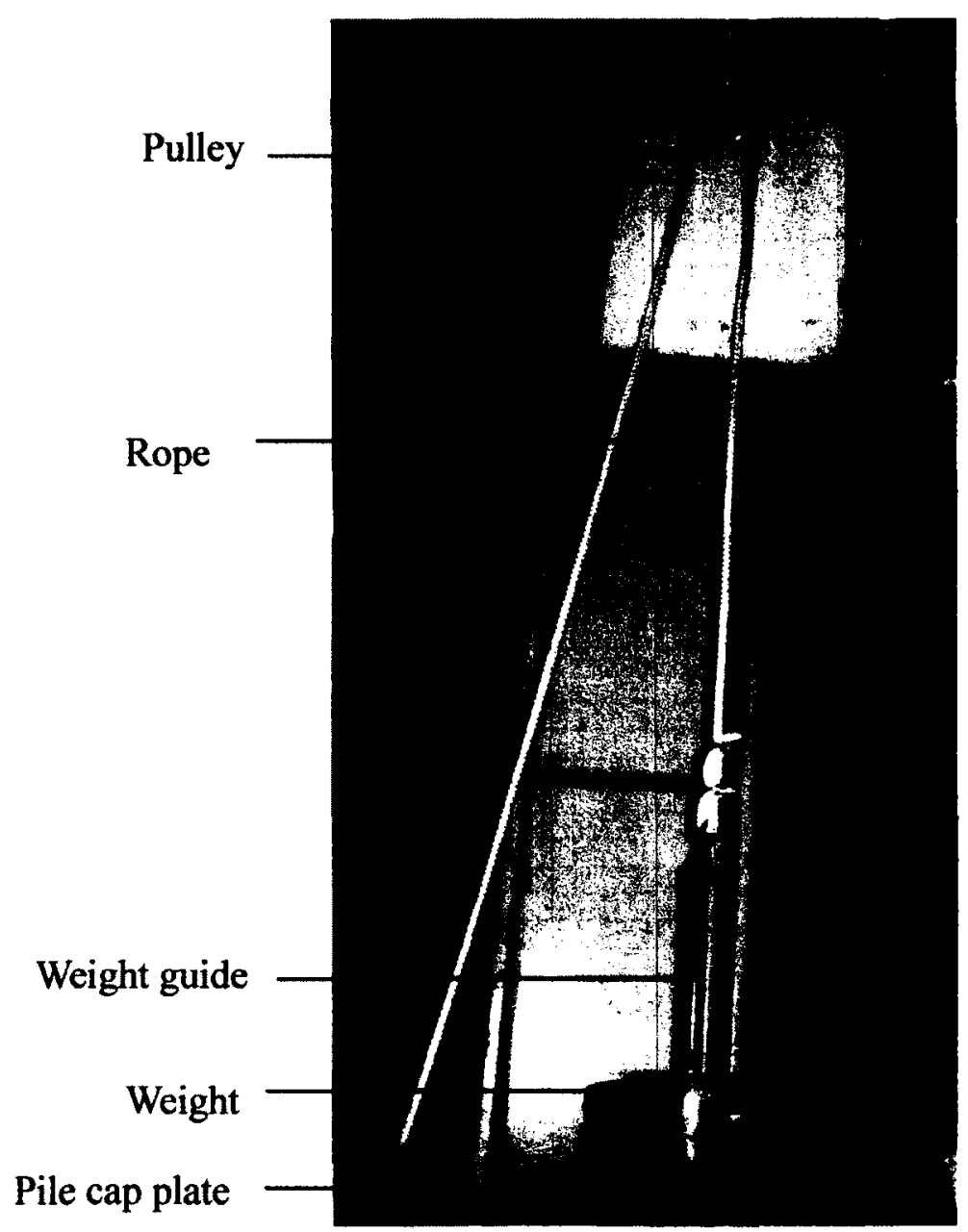

Figure 4.14: Pile driving setup

In order to monitor the driving force, the dropping weight, drop-height and number of blows required to advance the pile for each $50 \mathrm{~mm}$ segment were recorded. The applied energy $(J)$ for each pile is calculated by multiplying the drop-height $(\mathrm{m})$ by weight (N). Figure 4.15 illustrates a marked steel pipe pile at every $50 \mathrm{~mm}$ in length being driven into the soil barrel. 


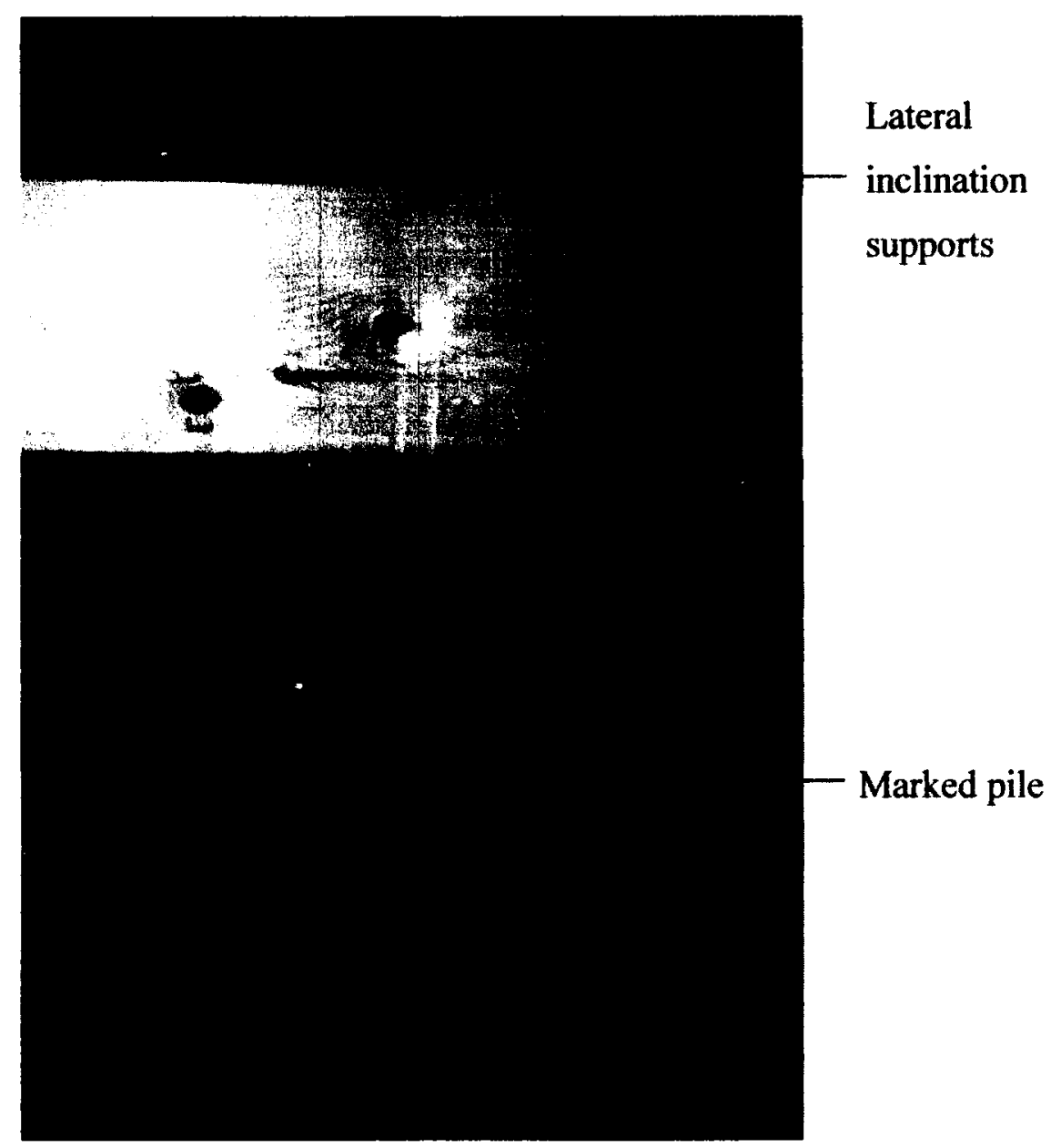

Figure 4.15: Steel pipe pile marked each $50 \mathrm{~mm}$ for driving

\subsubsection{Pore water pressure monitoring}

Effect of pore water pressure on pile setup has been described earlier in Chapter 2. Considering the importance of monitoring pore water pressure, a $0.07 \mathrm{MPa}$ vibrating wire piezometer was employed to monitor pore water pressure at pile tip during pile driving and testing. Specification sheet of the piezometer used in this experiment is provided in Appendix B. To install the piezometer, a $32 \mathrm{~mm}$ plastic pipe was employed to make a hole in 45 degree angle in the Leda clay. Location of the hole was designed to locate 
piezometer within $25 \mathrm{~mm}$ distance from pile tip when it is fully advanced into the Leda clay at the depth of $700 \mathrm{~mm}$ (Figure 4.16). After making the hole, a $50 \mathrm{~mm}$ thick layer of course sand was placed at the bottom of the hole, the piezometer was installed in the water-filled hole and the hole was sealed using construction grout. A data logger was utilized to continuously record pore water pressure through the experiment.

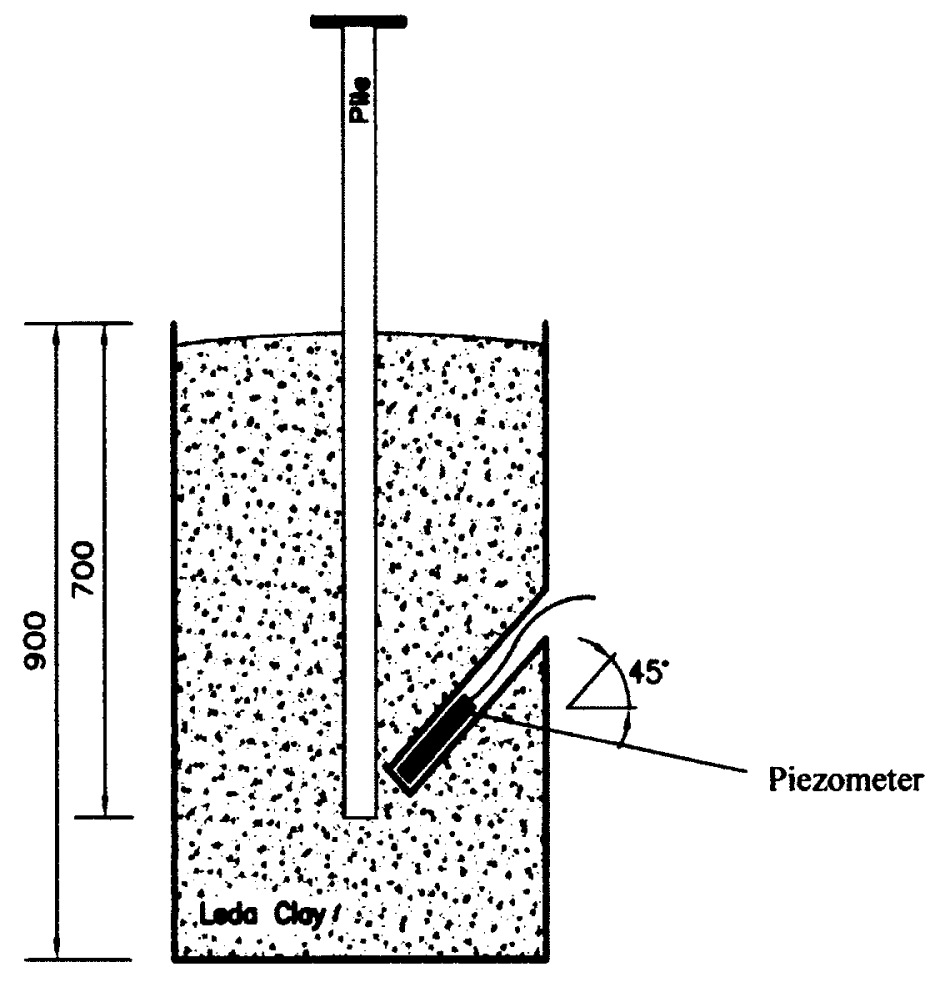

Figure 4.16: Piezometer location in barrel 


\subsubsection{Soil surface displacement}

As mentioned in literature review in Chapter 2, pile driving could cause the soil surface to be raised or heaved. This phenomenon is observed mostly when a displacement type of pile is driven. In this experiment, two digital indicators were employed to monitor the surface soil displacement; one located with a distance of $50 \mathrm{~mm}$ from the pile and the second one $25 \mathrm{~mm}$ away from the barrel edge.

\subsubsection{Pile load tests}

There are two major types of load testing used in pile industry including static load testing and dynamic load testing. For static load test, a hydraulic jack is used to apply the load and the magnitude of the applied load is measured by a load cell or a pressure gauge. The load is applied in a long period of time and raised gradually to reach the desired load. In dynamic testing, the maximum desired load is applied very quickly and the capacity is measured by retaining Pile Dynamic Analyzer (PDA) according to ASTM D4945.

Both static and dynamic pile load tests were used to measure the pile capacity. Static axial compressive and tensile loading tests were performed on the test piles in accordance with ASTM D 1143. A hydraulic jack with total ram height of $50 \mathrm{~mm}$ and a calibrated load cell for load measurement were employed (Figure 4.17). Load was applied to the pile in two directions of downward (compression) and upward (tension) and the loading was increased to the moment of pile failure. Right after failure, the pressure was released to avoid excessive soil disturbance. Displacement indicator were 
employed to measure the pile head displacement. Pile capacities were evaluated by plotting the load versus pile displacement data resulting from the load test.

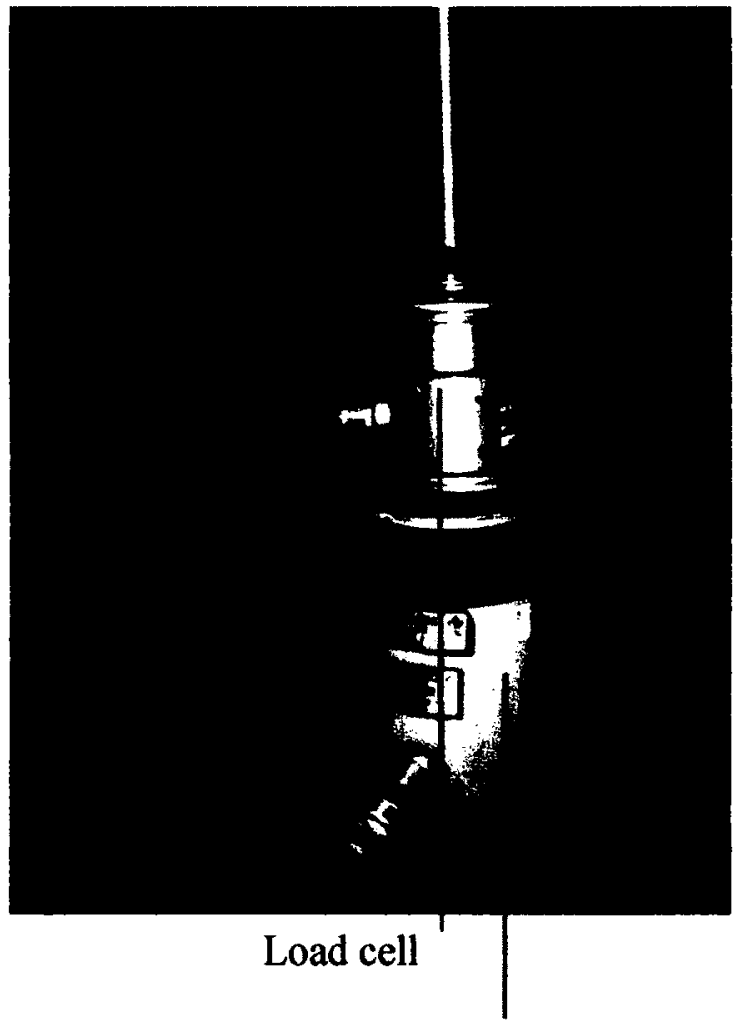

Hydraulic jack

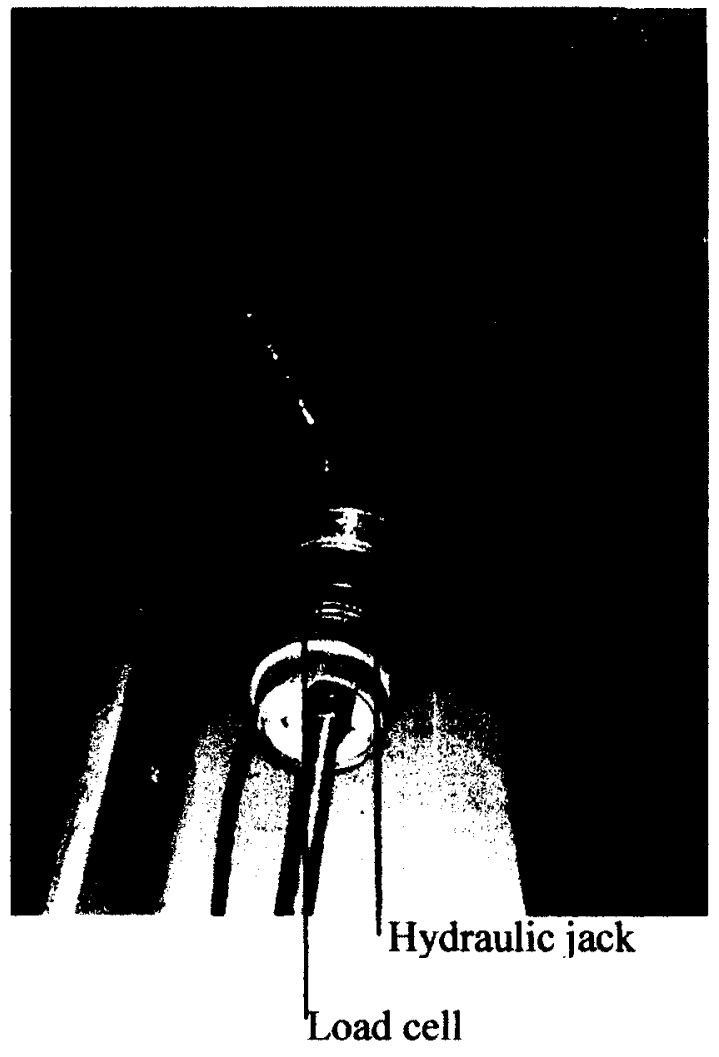

Figure 4.17: Static pile loading setup in tension (a) and compression (b) positions

Dynamic pile load testing was performed with a Pile Driving Analyzer (PDA). The PDA computes dynamic variables between hammer blows using the wave propagation theory for a uniform elastic pile. PDA sensors were installed on pile head and PDA analyzer was set on monitoring station (Figure 4.18). Pile displacements during testing were converted to forces and accelerations as a function of time for each hammer blow. Results from the PDA test include pile driving forces, hammer transferred energy and pile capacity. 

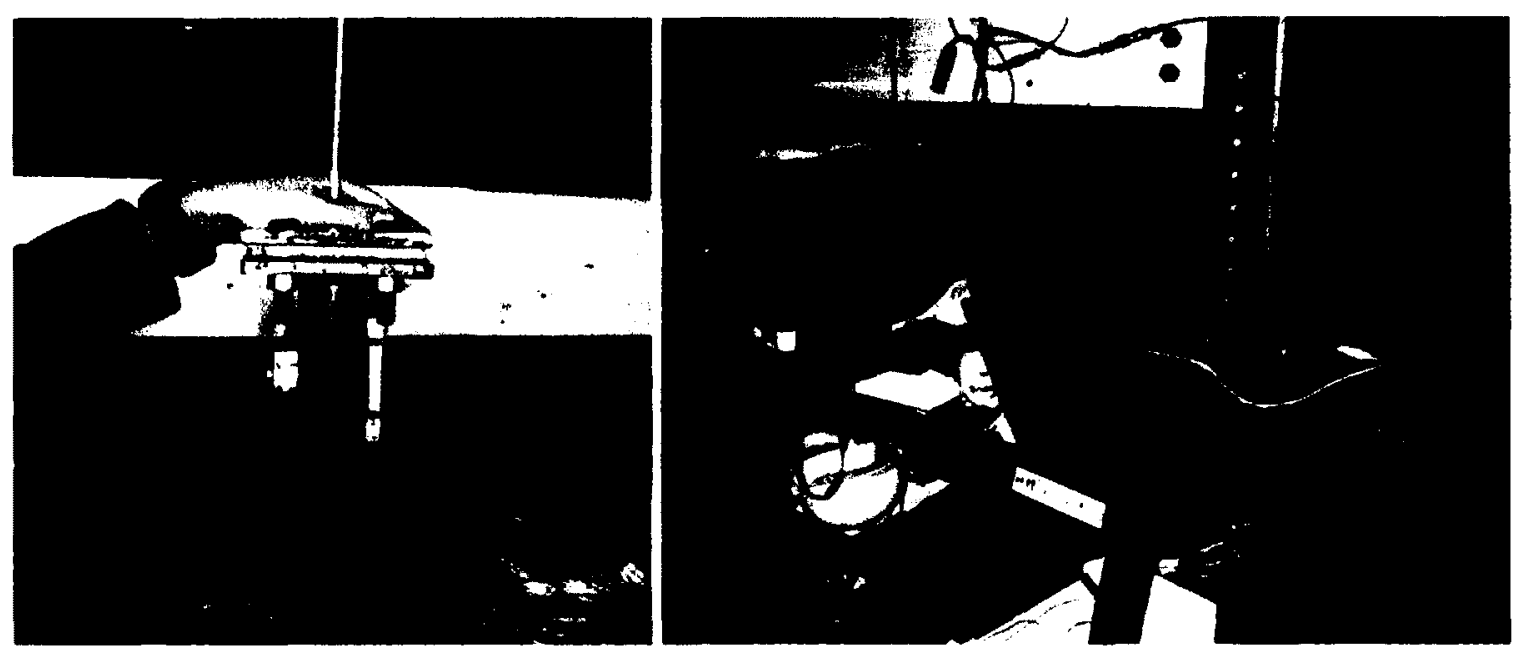

Figure 4.18: PDA sensors installed on a steel pile (left)

and PDA analyzer on monitoring station (right)

\subsection{Results}

A total of six piles were driven into the clay barrels and tested in this experiment. A variety of pile types and testing combinations were planned to cover major possible scenarios in pile foundations, such as closed end pile, open-end pile, static or dynamic loading and steel or concrete piles. All piles were tested immediately at the End Of Initial Driving (EOID), and repeated 1 day, 5 days and 12 days after initial driving. All piles were driven to a depth of $700 \mathrm{~mm}$ below the soil surface. A series of pile load test (P7) was also conducted in the field (Geotechnical Test Site in Gloucester) to verify the boundary conditions used in this experiment. Pile capacities were measured for each testing with an optimum required pile movement sufficient to obtain the pile maximum 
resistance. Table 4.2 presents a summary of tested piles and the measured maximum pile resistance for each experiment.

Table 4.2: Pile load test types and setup rate Summary

\begin{tabular}{ccc|c|c|c|c|c|c}
\hline Pile & Pile & Pile Toe & \multicolumn{2}{c|}{ Type of testing } & \multicolumn{4}{c}{ Pile capacity (N) } \\
\cline { 3 - 9 } Number & Material & Open/Closed & $\begin{array}{c}\text { Compression / } \\
\text { Tension }\end{array}$ & $\begin{array}{c}\text { Static/ } \\
\text { Dynamic }\end{array}$ & Initial & Day I & Day 5 & Day 12 \\
\hline P1 & Concrete & Closed & Tension & Static & 475 & 950 & 1006 & 1016 \\
P2 & Steel Pipe & Open & Compression & Static & 1874 & 2708 & 2892 & 3023 \\
P3 & Steel Pipe & Open & Tension & Static & 973 & 2993 & 3180 & 3125 \\
P4 & Steel Pipe & Closed & Compression & Dynamic & 1000 & 2200 & 3000 & 3000 \\
P5 & Steel Pipe & Closed & Compression & Static & 1661 & 2733 & 2974 & 2941 \\
P6 & Steel Pipe & Open & Tension & Static & 1025 & 2739 & 3241 & 3380 \\
P7 & Steel Pipe & Open & Tension & Static & 761 & 1784 & 2440 & 2537 \\
\hline
\end{tabular}

For each individual pile load testing, a series of data was obtained. While pile was driven, penetration resistance (PRES) and applied energy to drive the pile was recorded. The pore water pressure and soil surface displacement was also recorded for displacement piles.

\subsubsection{Pile number 1 (P1)}

In experiment $1(\mathrm{P} 1)$, a $48 \mathrm{~mm}$ diameter precast armed concrete pile was employed to investigate the pile setup in clay. The pile was driven into the clay to a depth of $700 \mathrm{~mm}$ below soil surface using a $138 \mathrm{~N}$ weight with drop heights of 50 and $100 \mathrm{~mm}$. Pile driving record of $\mathrm{P} 1$ has been presented in Table 4.3. A static pile load test was performed immediately at EIOD using a hydraulic jack and load cell to determine the initial pile shaft capacity at tension. Pile load tests were also repeated 1,5 and 12 days 
after initial load test to study the evolution of the pile capacity with time. Figure 4.19 presents the tension capacity versus displacement for each load test. The tension capacity increased from an initial value of about 475 to $950 \mathrm{~N}$, one day after initial pile load test. This capacity reached a maximum value of about $1016 \mathrm{~N}, 12$ days after initial testing.

Pore water pressure (PWP) was monitored using a piezomoter located approximately $25 \mathrm{~mm}$ apart from where pile toe has been rested and was measured throughout the testing. The result of PWP versus log-time has been illustrated in Figure 4.20. As shown, PWP was increased significantly when the pile tip approaches toward piezometer location. At the time of any testing, a small change in PWP was observed and after day 4 to day 12, PWP was stabilized and stayed consistent. These results are in general agreement with fundamental observations on the time-dependent pile capacity increase which is related, at least in part, to the dissipation of excess pore water pressure in the pile surrounding soil. After pile driving, excess pore water pressures in the surrounding soil begin to dissipate. As pore water pressures dissipate, the effective stress increases, and the soil around the pile consolidates and gains strength.

Figure 4.21 presents the measured maximum pile resistance at each test versus the elapsed time. A significant pile capacity increase for pile load test, performed 1 day after initial driving is observed. This rate slightly decreased as the elapsed time increased from 1 to 12 days. This could be related to faster dissipation of excess pore water pressure and a higher rate of consolidation of the soil in earlier stages. 
Table 4.3: Pile driving record for Pile 1

\begin{tabular}{ccccc}
\hline \multicolumn{5}{c}{$\left(\begin{array}{c}\text { PI) Pre-cast driven concrete pile, tested at TENSION } \\
\text { 48 } \mathbf{m m} \text { Dia, } \mathbf{1 4 5 0} \text { mm Length }\end{array}\right.$} \\
\hline Depth & Blow-count & Drop height & Weight & Applied energy - PI \\
$(\mathbf{m m})$ & $\#$ & mm & N & J \\
\hline $\mathbf{5 0}$ & 2 & 50 & 138 & 6.9 \\
$\mathbf{1 0 0}$ & 10 & 50 & 138 & 6.9 \\
$\mathbf{1 5 0}$ & 15 & 100 & 138 & 13.8 \\
$\mathbf{2 0 0}$ & 8 & 100 & 138 & 13.8 \\
$\mathbf{2 5 0}$ & 10 & 100 & 138 & 13.8 \\
$\mathbf{3 0 0}$ & 10 & 100 & 138 & 13.8 \\
$\mathbf{3 5 0}$ & 13 & 100 & 138 & 13.8 \\
$\mathbf{4 0 0}$ & 13 & 100 & 138 & 13.8 \\
$\mathbf{4 5 0}$ & 18 & 100 & 138 & 13.8 \\
$\mathbf{5 0 0}$ & 13 & 100 & 138 & 13.8 \\
$\mathbf{5 5 0}$ & 11 & 100 & 138 & 13.8 \\
$\mathbf{6 0 0}$ & 21 & 100 & 138 & 13.8 \\
$\mathbf{6 5 0}$ & 8 & 100 & 138 & 13.8 \\
$\mathbf{7 0 0}$ & 10 & 100 & 138 & 13.8 \\
\hline
\end{tabular}

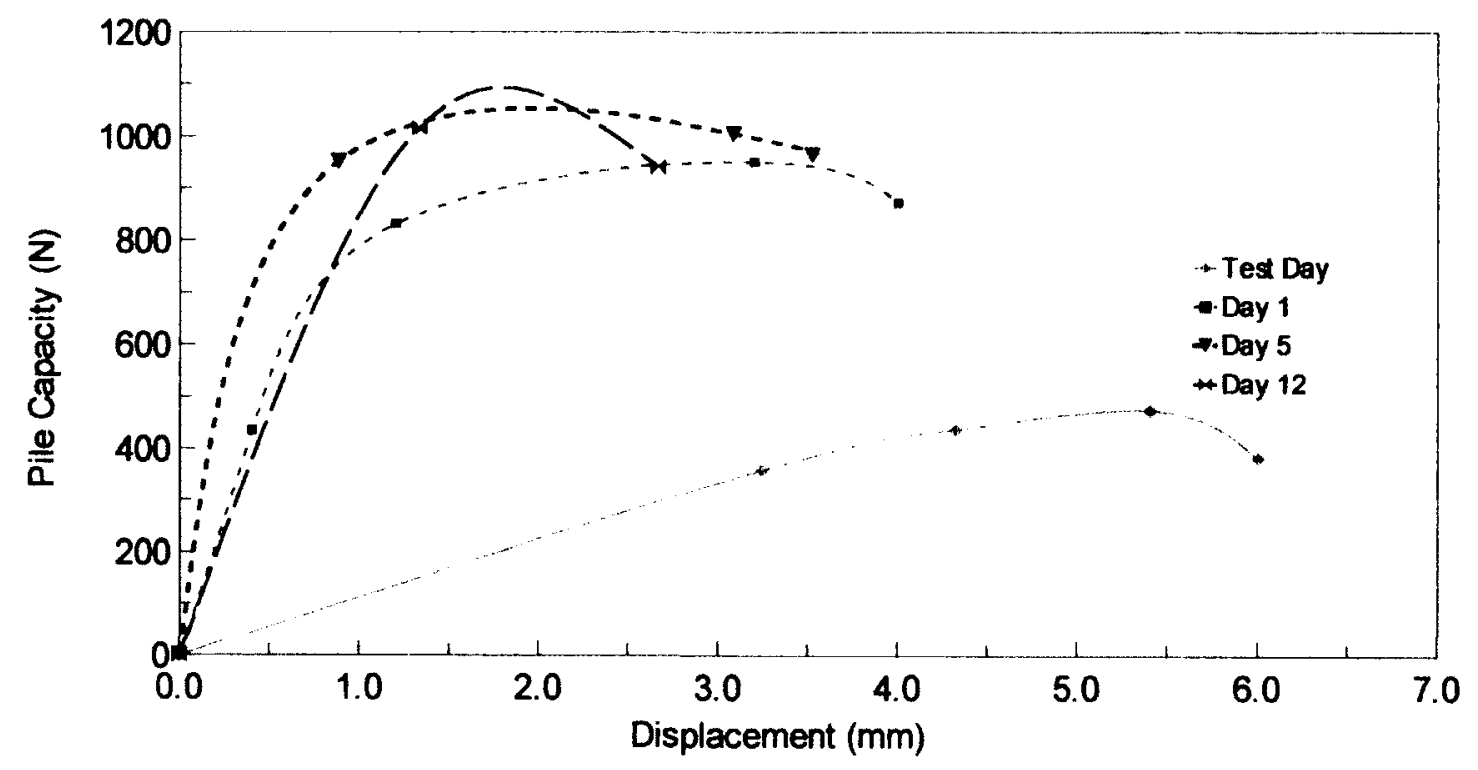

Figure 4.19: Pile capacity versus displacement for Pile 1 


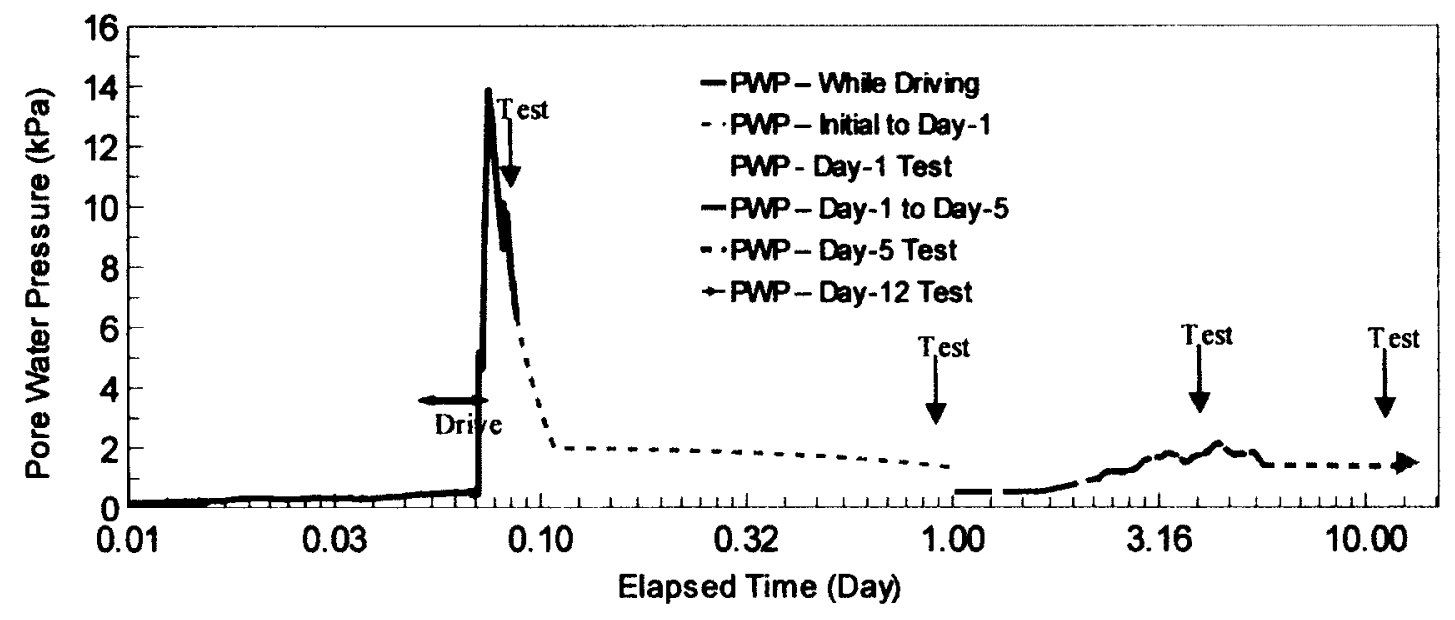

Figure 4.20: Pore water pressure versus log-time for Pile 1

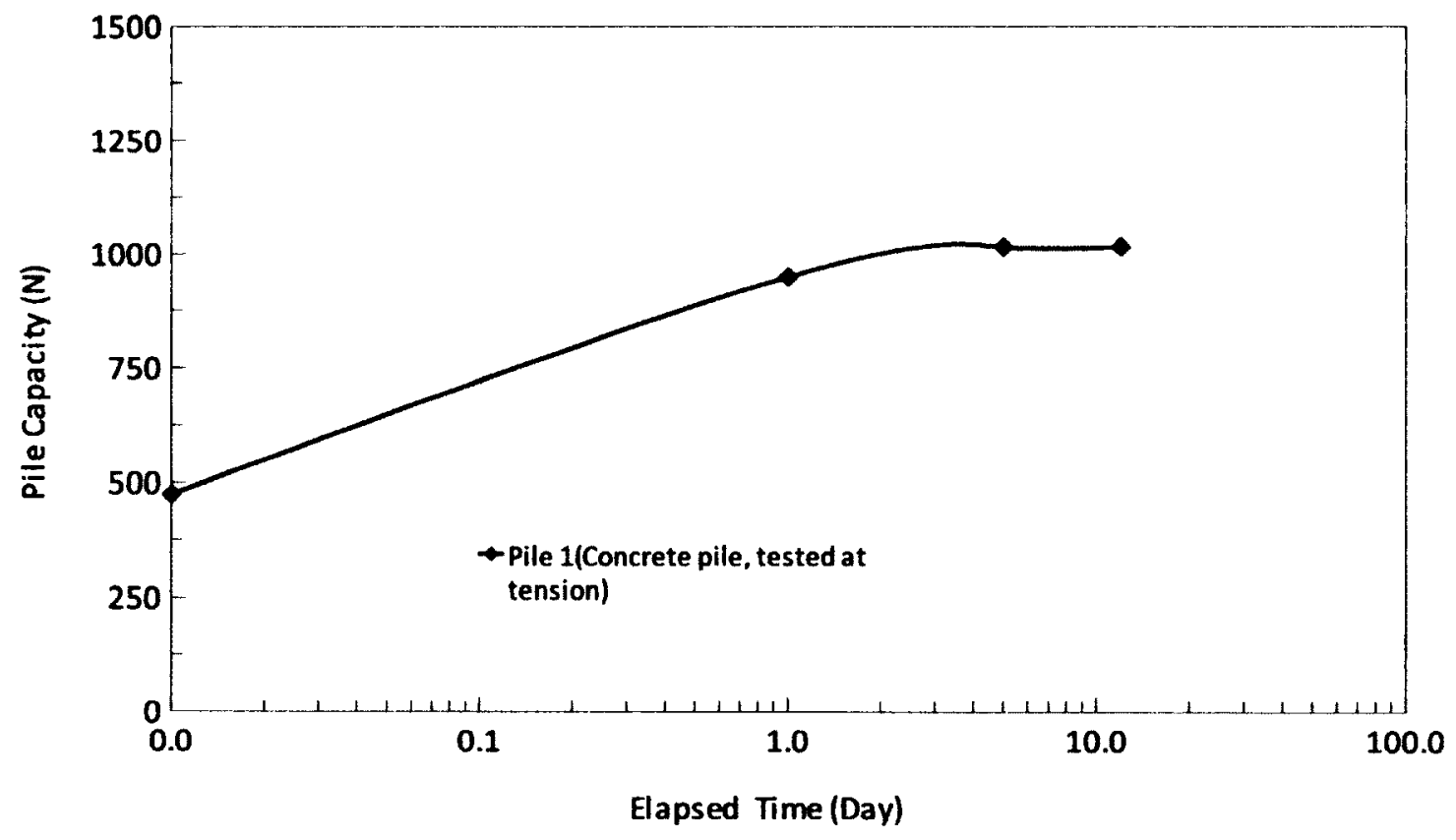

Figure 4.21: Pile capacity versus time for Pile 1 


\subsubsection{Pile number 2 (P2)}

In experiment $2(\mathrm{P} 2)$, an open toe steel pipe pile with $48 \mathrm{~mm}$ outside diameter and $3.7 \mathrm{~mm}$ wall thickness, was employed to investigate the pile setup in clay. A $90 \mathrm{~N}$ weight with drop heights of 150 and $200 \mathrm{~mm}$ was used to drive the pile into the clay. Pile driving record of $\mathrm{P} 2$ has been presented in Table 4.4. Pile was tested at compression immediately after driving using a hydraulic jack and a load cell to determine the initial total pile capacity. The total pile capacity consists of frictional shaft capacity and end bearing. Pile load tests were also repeated 1,5 and 12 days after initial load test to study the evolution of the pile capacity with time. The pile capacity versus displacement for each load test has been presented in Figure 4.22. The pile capacity was measured at $1874 \mathrm{~N}$ immediately after driving and increased to $2708 \mathrm{~N}$, one day after initial pile load test. 12 days after initial testing, the pile capacity reached its maximum value of about $3023 \mathrm{~N}$. After pile driving, the excess pore water pressures generated during pile driving begin to dissipate. As pore water pressures dissipate, the effective stress increases, and the soil around the pile consolidates and gains strength. 
Table 4.4: Pile driving record for Pile 2

\begin{tabular}{|c|c|c|c|c|}
\hline \multicolumn{5}{|c|}{$\begin{array}{l}\text { (P2) Open toe steel pipe pile, tested at COMPRESSION } \\
48 \mathrm{~mm} \text { OD, } 3.7 \mathrm{~mm} \mathrm{WT}, 1450 \mathrm{~mm} \text { Length }\end{array}$} \\
\hline $\begin{array}{l}\text { Depth } \\
(\mathrm{mm})\end{array}$ & $\begin{array}{c}\text { Blow-count } \\
\#\end{array}$ & $\begin{array}{c}\text { Drop height } \\
\mathrm{mm}\end{array}$ & $\begin{array}{l}\text { Weight } \\
N\end{array}$ & $\begin{array}{c}\text { Applied energy }-P 2 \\
J\end{array}$ \\
\hline 50 & 4 & 150 & 90 & 13.5 \\
\hline 100 & 3 & 150 & 90 & 13.5 \\
\hline 150 & 6 & 150 & 90 & 13.5 \\
\hline 200 & 9 & 150 & 90 & 13.5 \\
\hline 250 & 11 & 150 & 90 & 13.5 \\
\hline 300 & 8 & 200 & 90 & 18.0 \\
\hline 350 & 9 & 200 & 90 & 18.0 \\
\hline 400 & 8 & 200 & 90 & 18.0 \\
\hline 450 & 8 & 200 & 90 & 18.0 \\
\hline 500 & 9 & 200 & 90 & 18.0 \\
\hline $\mathbf{5 5 0}$ & 10 & 200 & 90 & 18.0 \\
\hline 600 & 10 & 200 & 90 & 18.0 \\
\hline 650 & 10 & 200 & 90 & 18.0 \\
\hline 700 & 9 & 200 & 90 & 18.0 \\
\hline
\end{tabular}

Figure 4.23 presents the obtained maximum pile capacity of the pile with elapsed time. As shown, the rate of increase was relatively higher at one day after driving, compare to later stages. This rate slightly decreased as the elapsed time increased from 1 to 12 days. This significant capacity increase within one day after initial drive, could explain that the generated excess pore water pressure induced by pile driving is dissipated with a faster rate in the early stage of testing and rate of dissipation of PWP, decreased after day 1 to 12 . 


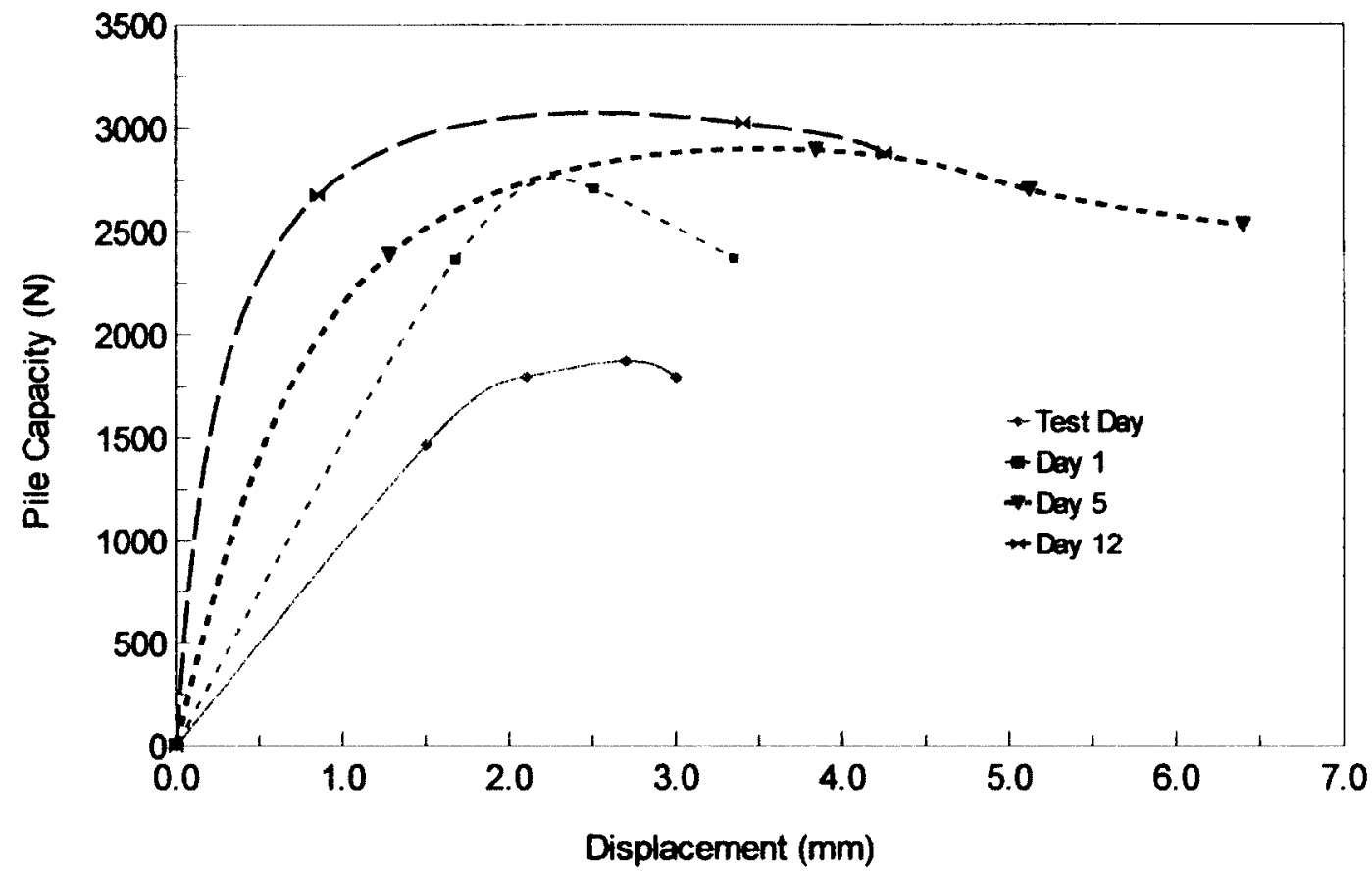

Figure 4.22: Pile capacity versus displacement for Pile 2

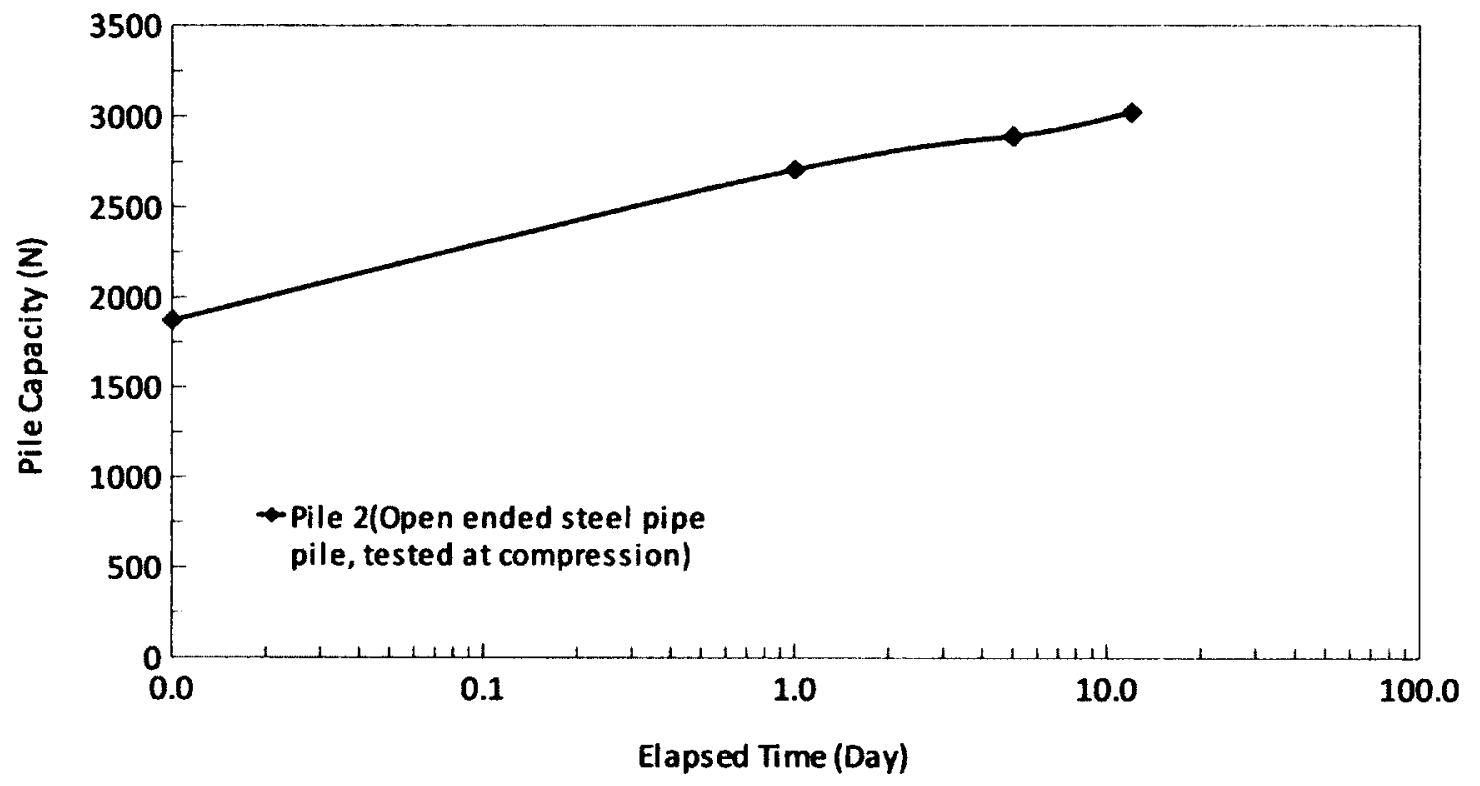

Figure 4.23: Rate of pile setup versus time for Pile 2 


\subsubsection{Pile number $3(\mathrm{P3})$}

In experiment $3(\mathrm{P} 3)$, an open end steel pipe pile with outside diameter of $48 \mathrm{~mm}$ and $3.7 \mathrm{~mm}$ wall thickness was driven into the clay using a $90 \mathrm{~N}$ weight with drop heights of 150 and $200 \mathrm{~mm}$. Pile driving record of P3 has been presented in Table 4.5. Pile 3 was tested at tension using a hydraulic jack and load cell at EIOD to determine the initial pile shaft capacity. Pile load tests were also repeated 1,5 and 12 days after initial load test. Figure 4.24 presents the tension capacity versus displacement for each load test. Initially, friction pile capacity of $973 \mathrm{~N}$ was measured immediately after driving and it was significantly increased to $2993 \mathrm{~N}$, one day after initial pile load test. This capacity reached a maximum value of about $3180 \mathrm{~N}, 5$ days after initial testing. Pile capacity indicates a slight decrease of $155 \mathrm{~N}$ in capacity at 12-day test which is considered as testing setup error due to the rate of loading. The result presents a confirmation of pile capacity increase with time. To investigate the pile capacity setup in relation with time, the maximum measured pile capacity at day-1, day-5 and day-12 were shown in Figure 4.25. The rate of pile setup has been increased significantly at day-1 test with, an estimation of $300 \%$ increase. Approximately, pile capacity remains constant after day-1 test to the day-12 test. 
Table 4.5: Pile driving record for Pile 3

\begin{tabular}{|c|c|c|c|c|}
\hline \multicolumn{5}{|c|}{$\begin{array}{l}\text { (P3) Open toe steel pipe pile, tested at TENSION } \\
48 \mathrm{~mm} \text { OD, } 3.7 \mathrm{~mm} \text { WT, } 1450 \mathrm{~mm} \text { Length }\end{array}$} \\
\hline $\begin{array}{l}\text { Depth } \\
(\mathrm{mm})\end{array}$ & $\begin{array}{c}\text { Blow-count } \\
\#\end{array}$ & $\begin{array}{c}\text { Drop height } \\
\text { mm }\end{array}$ & $\begin{array}{l}\text { Weight } \\
N\end{array}$ & $\begin{array}{c}\text { Applied energy - P3 } \\
J\end{array}$ \\
\hline 50 & 2 & 150 & 90 & 13.5 \\
\hline 100 & 3 & 150 & 90 & 13.5 \\
\hline 150 & 5 & 150 & 90 & 13.5 \\
\hline 200 & 7 & 150 & 90 & 13.5 \\
\hline 250 & 8 & 150 & 90 & 13.5 \\
\hline 300 & 10 & 200 & 90 & 18.0 \\
\hline 350 & 7 & 200 & 90 & 18.0 \\
\hline 400 & 8 & 200 & 90 & 18.0 \\
\hline 450 & 9 & 200 & 90 & 18.0 \\
\hline 500 & 9 & 200 & 90 & 18.0 \\
\hline 550 & 7 & 200 & 90 & 18.0 \\
\hline 600 & 9 & 200 & 90 & 18.0 \\
\hline 650 & 10 & 200 & 90 & 18.0 \\
\hline 700 & 10 & 200 & 90 & 18.0 \\
\hline
\end{tabular}

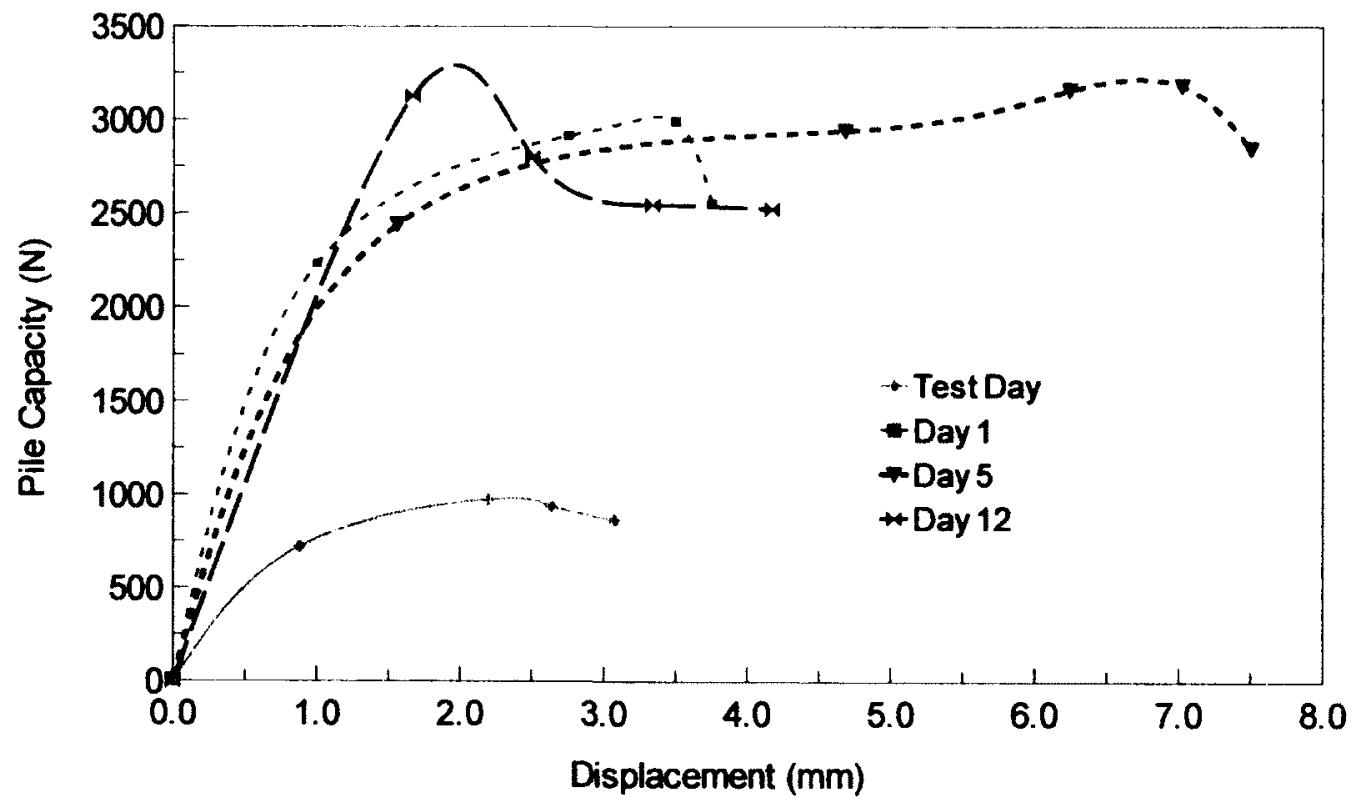

Figure 4.24: Pile capacity versus displacement for Pile 3 


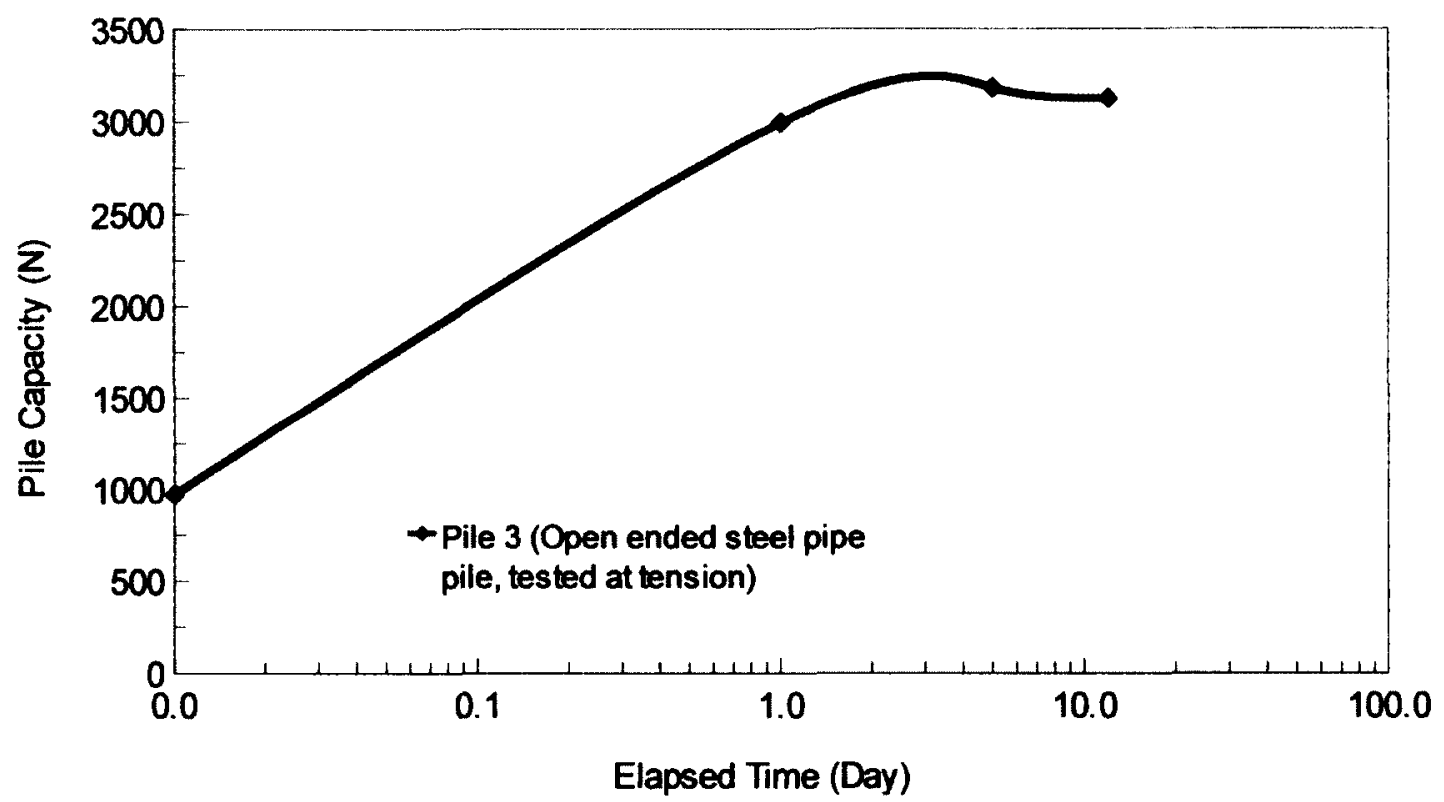

Figure 4.25: Rate of pile setup versus time for Pile 3

\subsubsection{Pile number $4(\mathbf{P 4})$}

In experiment 4 (P4), a closed toe steel pipe pile with $48 \mathrm{~mm}$ diameter was employed to investigate rate of pile capacity increase with time for driven pile in clay. Pile was driven using a $90 \mathrm{~N}$ weight with drop heights of 100 and $200 \mathrm{~mm}$ into the clay while monitoring by Pile Dynamic Analyzer (PDA). Pile driving record of P4 is presented in Table 4.6. Pile 4 was struck using a $90 \mathrm{~N}$ weight and drop height of $800 \mathrm{~mm}$ while was monitored by PDA. Compression tests were performed immediately after driving as well as different elapsed times. Pile driving analyzer contains of a data collector, strain gauges and 
accelerometers. Available PDA system is designed to measure large-scale strain and acceleration, the measurement accuracy in the lower spectrum of these physical values becomes very low, especially for strain measurements. As the strain application on piles for this experiment is very low, the PDA result may not be accurate. A total of four CAPWAP analyses were performed for the pile on selected blow records to determine the resistance distribution and soil parameters for evaluating the test results. As an estimate, a compression capacity of $1000 \mathrm{~N}$ was computed at initial drive and the pile reached a capacity of $3000 \mathrm{~N}$ after 12 days. Estimated computed pile capacity versus time has been presented in Figure 4.26.

Pore water pressure was monitored at pile toe location for this experiment. Figure 4.27 presents the pore water pressure evolution versus log-time throughout testing. As shown, PWP was increased significantly while pile was being penetrated passing piezometer location and it started dissipating shortly after. Also PWP has been changed at the time of each testing. After day-1, PWP stayed consistent and stabilized through the rest of testing. As shown in Table 4.6, Pile 7 was terminated with penetration resistance (PRES) of 6 blows per $50 \mathrm{~mm}$ using $18.0 \mathrm{~J}$ applied energy at initial drive. A PRES of 10 blows per $50 \mathrm{~mm}$ using applied energy of $54 \mathrm{~J}$ after one day and a PRES of 8 blows per $50 \mathrm{~mm}$ using $72 \mathrm{~J}$ applied energy at day 5 and 12 after initial drive were obtained. This increase in penetration resistance attributes to an increase in pile capacity which is in corresponds with computed pile capacities. 
Table 4.6: Pile driving record for Pile 4

\begin{tabular}{|c|c|c|c|c|}
\hline \multicolumn{5}{|c|}{$\begin{array}{c}\text { (P4)Closed toe steel pipe pile, tested at COMPRESSION (PDA) } \\
48 \mathrm{~mm} O D, 3.7 \mathrm{~mm} W T, 1450 \mathrm{~mm} \text { Length }\end{array}$} \\
\hline $\begin{array}{l}\text { Depth } \\
(\mathrm{mm})\end{array}$ & $\begin{array}{c}\text { Blow-count } \\
\#\end{array}$ & $\begin{array}{l}\text { Drop height } \\
\mathrm{mm}\end{array}$ & $\begin{array}{c}\text { Weight } \\
\text { kg }\end{array}$ & $\begin{array}{c}\text { Applied energy -P4 } \\
\mathrm{J}\end{array}$ \\
\hline 50 & 5 & 100 & 90 & 9.0 \\
\hline 100 & 7 & 100 & 90 & 9.0 \\
\hline 150 & 7 & 100 & 90 & 9.0 \\
\hline 200 & 9 & 200 & 90 & 18.0 \\
\hline 250 & 6 & 200 & 90 & 18.0 \\
\hline 300 & 6 & 200 & 90 & 18.0 \\
\hline 350 & 6 & 200 & 90 & 18.0 \\
\hline 400 & 10 & 200 & 90 & 18.0 \\
\hline 450 & 7 & 200 & 90 & 18.0 \\
\hline 500 & 11 & 200 & 90 & 18.0 \\
\hline $\mathbf{5 5 0}$ & 8 & 200 & 90 & 18.0 \\
\hline 600 & 6 & 200 & 90 & 18.0 \\
\hline 650 & 6 & 200 & 90 & 18.0 \\
\hline 700 & 6 & 200 & 90 & 18.0 \\
\hline
\end{tabular}

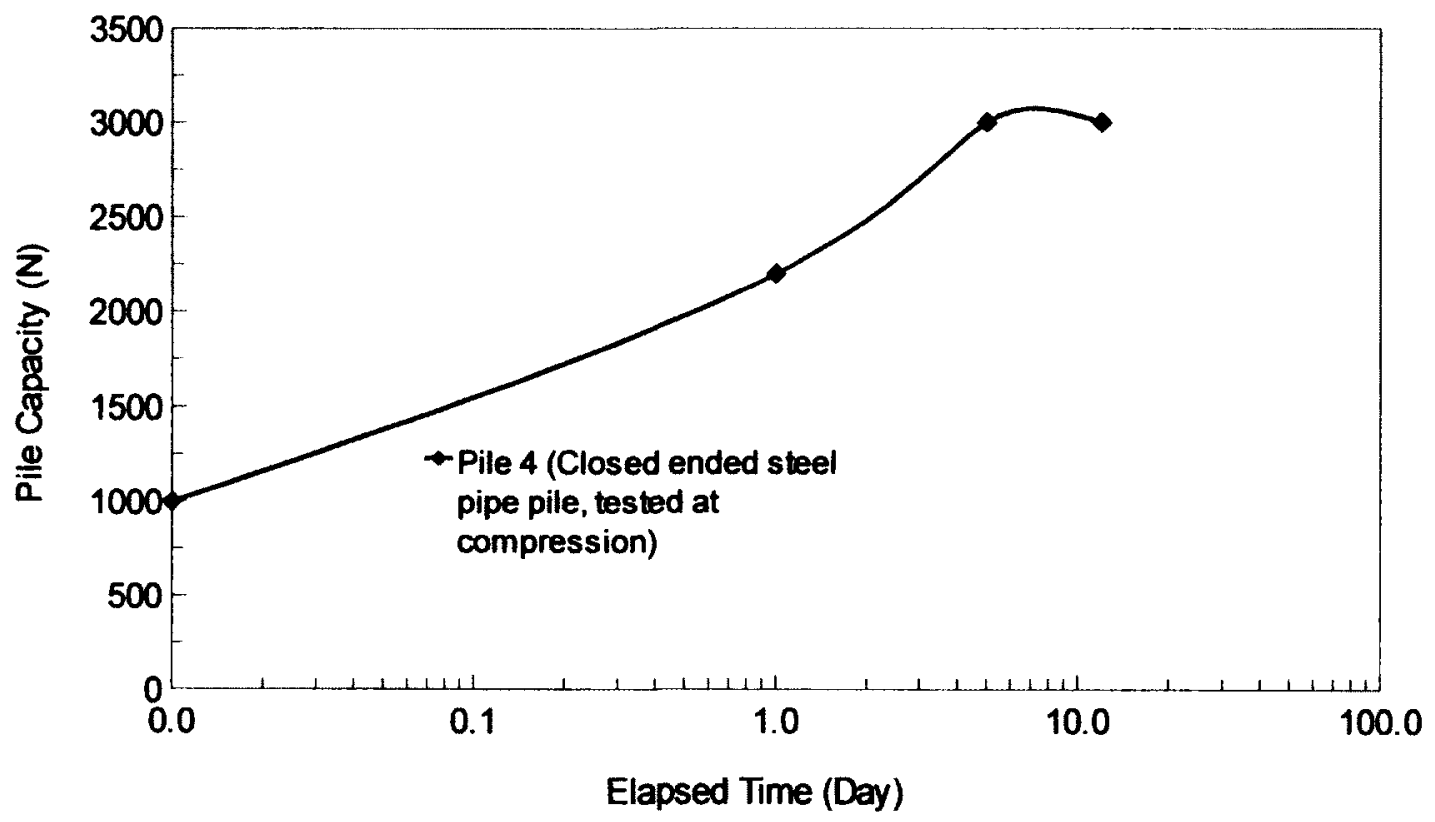

Figure 4.26: Pile capacity versus displacement for Pile 4 


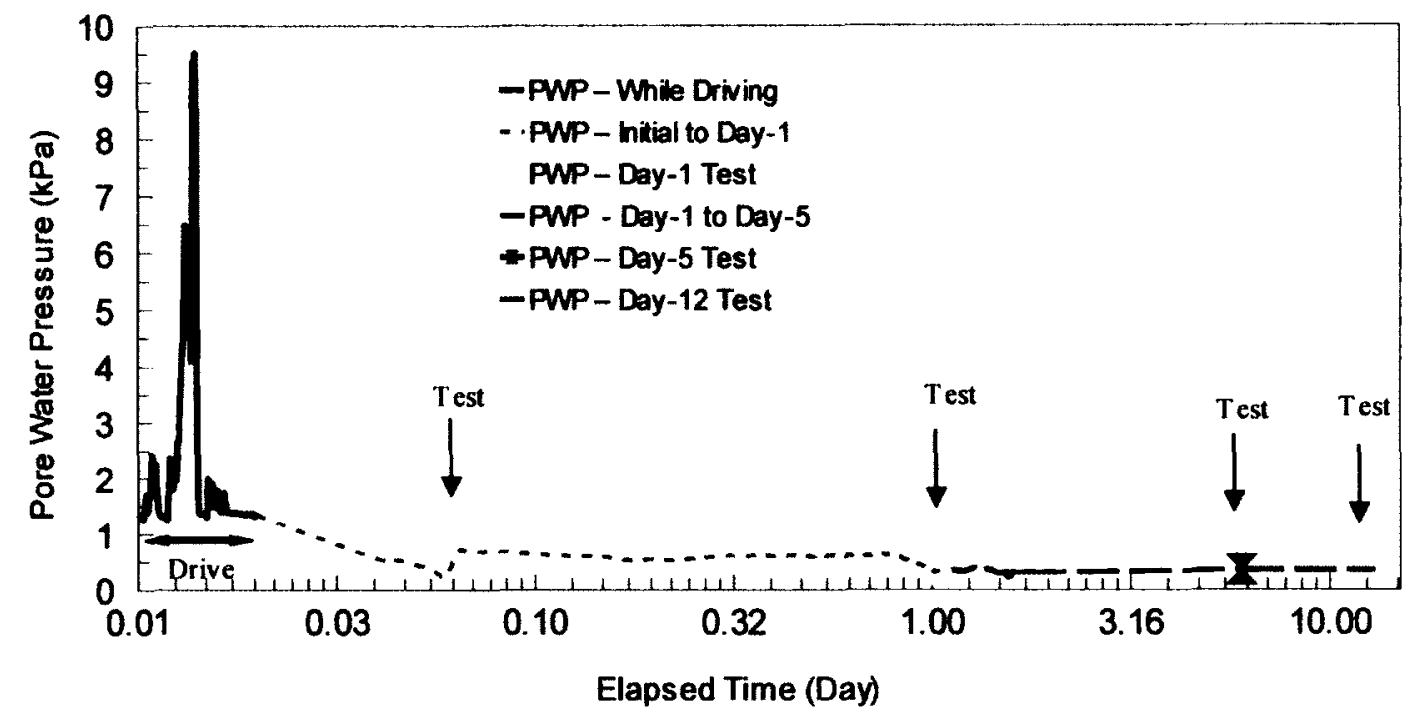

Figure 4.27: Pore water pressure versus log-time for Pile 4

\subsubsection{Pile number 5 (P5)}

In experiment 5 (P5), a closed end steel pipe pile was selected to study the pile setup in clay. A $90 \mathrm{~N}$ weight with drop heights of 100,150 and $200 \mathrm{~mm}$ were retained to drive the pile (Table 4.7). Pile capacity versus displacement for each load test has been presented in Figure 4.28. Compression capacity of pile 5 was measured at $1661 \mathrm{~N}$ immediately after driving. Pile capacity increased to $2733 \mathrm{~N}$, one day after initial pile load test and reached its maximum of $2941 \mathrm{~N}, 12$ days after initial testing. A vibrating piezometer was retained to monitor pore water pressure evolution at tip toe location for this experiment. 
As shown in Figure 4.29, as the pile tip travels during driving, PWP increased. The excess PWP decreased shortly after driving and started to stabilize one day after testing. As shown in Figure 4.30 , the pile setup at day-1 of testing was distinguished at $160 \%$ of initial capacity which is a very intense indication of pore water dissipation in a very short time period of one day. Pile setup rate increased $180 \%$ four days after initial driving, which could be an implication of slow rate of PWP dissipation.

Table 4.7: Pile driving record for Pile 5

\begin{tabular}{|c|c|c|c|c|}
\hline \multicolumn{5}{|c|}{$\begin{array}{l}\text { (P5)Closed toe steel pipe pile, tested at COMPRESSION } \\
48 \mathrm{~mm} \text { OD, } 3.7 \mathrm{~mm} W T, 1450 \mathrm{~mm} \text { Length }\end{array}$} \\
\hline $\begin{array}{l}\text { Depth } \\
(\mathrm{mm})\end{array}$ & $\begin{array}{c}\text { Blow-count } \\
\# \\
\end{array}$ & $\begin{array}{c}\text { Drop height } \\
\text { mm }\end{array}$ & $\begin{array}{c}\text { Weight } \\
N\end{array}$ & $\begin{array}{c}\text { Applied energy - P5 } \\
J\end{array}$ \\
\hline 50 & 5 & 100 & 90 & 9.0 \\
\hline 100 & 7 & 100 & 90 & 9.0 \\
\hline 150 & 10 & 100 & 90 & 9.0 \\
\hline 200 & 7 & 150 & 90 & 13.5 \\
\hline 250 & 10 & 150 & 90 & 13.5 \\
\hline 300 & 13 & 150 & 90 & 13.5 \\
\hline 350 & 9 & 200 & 90 & 18.0 \\
\hline 400 & 11 & 200 & 90 & 18.0 \\
\hline 450 & 12 & 200 & 90 & 18.0 \\
\hline 500 & 14 & 200 & 90 & 18.0 \\
\hline 550 & 9 & 200 & 90 & 18.0 \\
\hline 600 & 8 & 200 & 90 & 18.0 \\
\hline 650 & 7 & 200 & 90 & 18.0 \\
\hline 700 & 8 & 200 & 90 & 18.0 \\
\hline
\end{tabular}




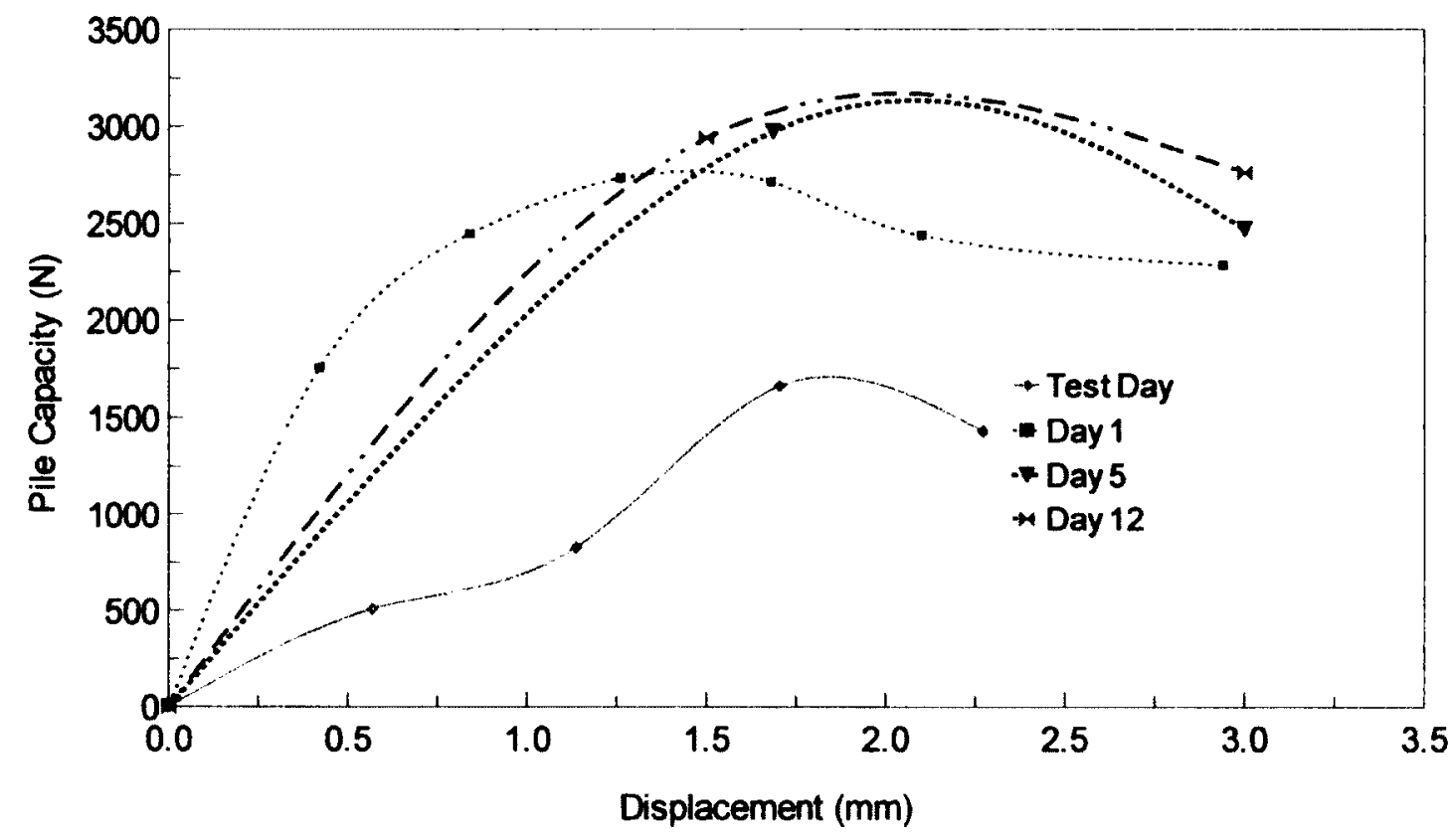

Figure 4.28: Pile capacity versus displacement for Pile 5

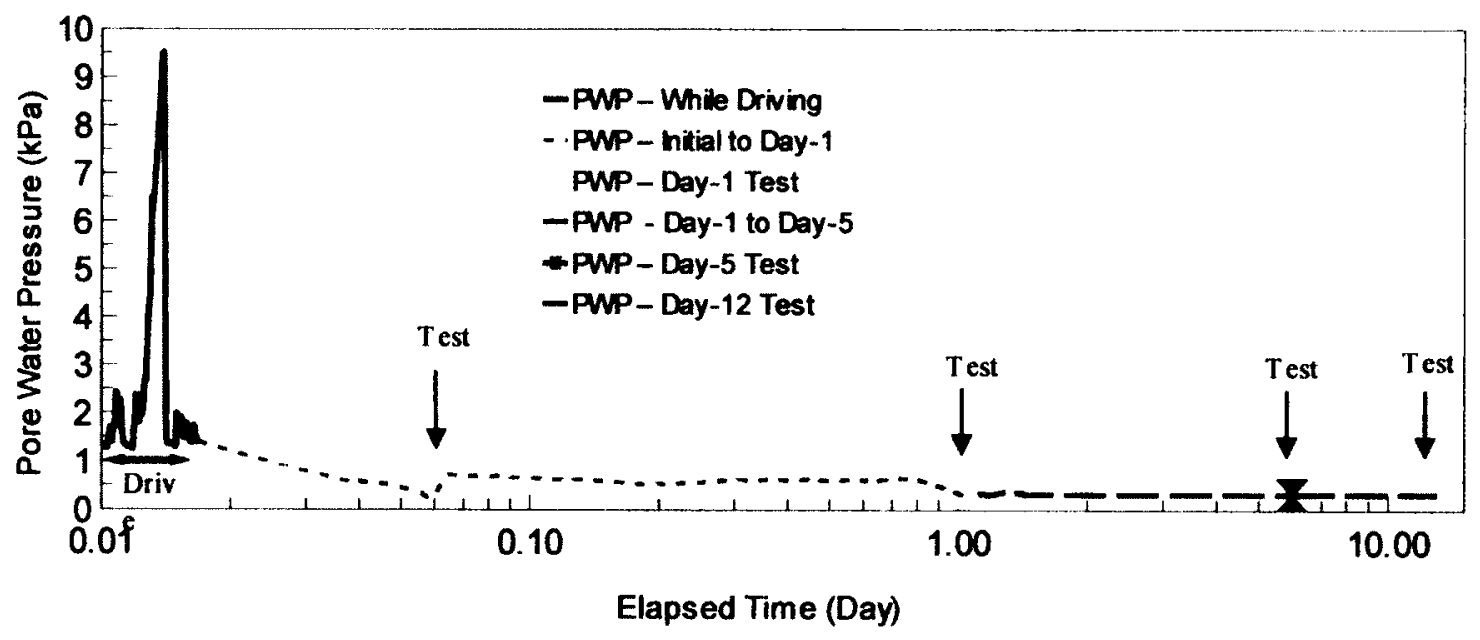

Figure 4.29: Pore water pressure versus log-time for Pile 5 


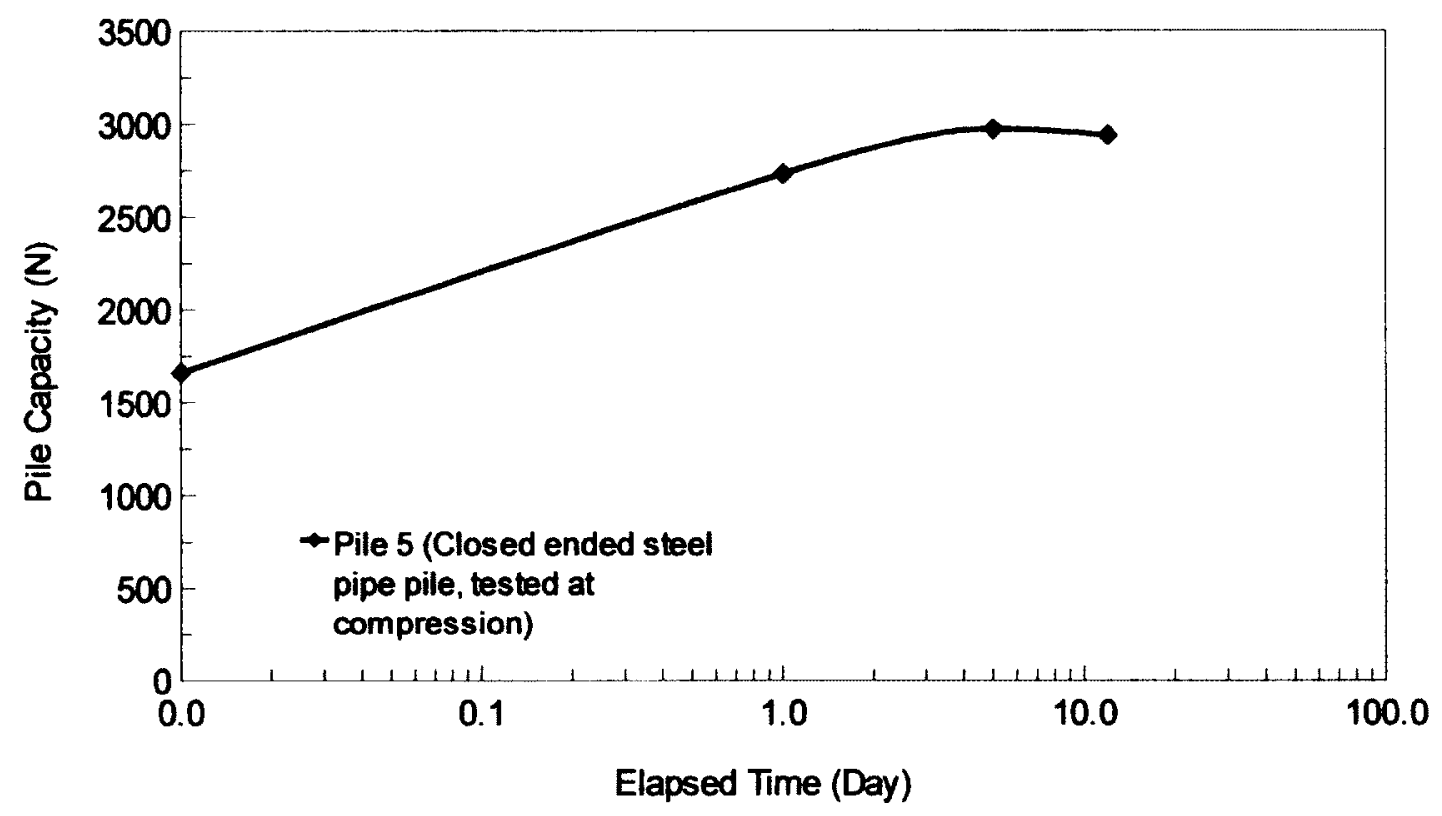

Figure 4.30: Rate of pile setup versus time for Pile 5

\subsubsection{Pile number 6 (P6)}

In experiment $6(\mathrm{P} 6)$, an open end steel pipe pile was driven using a $90 \mathrm{~N}$ weight with drop heights of 100,150 and $200 \mathrm{~mm}$ (Table 4.8). This test was similar to experiment 3 and conducted to study the repeatability of pile load results. Tension pile capacity versus pile displacement for this experiment is presented in Figure 4.31. Immediately after driving, tension pile capacity of $1025 \mathrm{~N}$ was measured and it was significantly increased to $2739 \mathrm{~N}$ one day after initial pile load test. This capacity reached a maximum value of about $3380 \mathrm{~N}, 12$ days after initial testing. The maximum pile 
capacity obtained at different stages, were plotted in Figure 4.32. As shown, the rate of pile setup has been increased significantly at day- 1 test, to a value of $270 \%$ increase, and a slight increase was observed since day-1 till day-12 tension load test. The results are fairly similar to the data obtained from P3, indicating that the pile load tests are reasonably repeatable. Thus the results from these experiments could be used for similar applications anywhere less.

Table 4.8: Pile driving record for Pile 6

\begin{tabular}{|c|c|c|c|c|}
\hline \multicolumn{5}{|c|}{$\begin{array}{c}\text { (P6)Open toe steel pipe pile, tested at TENSION } \\
48 \mathrm{~mm} \text { OD, } 3.7 \mathrm{~mm} W T, 1450 \mathrm{~mm} \text { Length }\end{array}$} \\
\hline $\begin{array}{l}\text { Depth } \\
\text { (mm) }\end{array}$ & $\begin{array}{c}\text { Blow-count } \\
\# \\
\end{array}$ & $\begin{array}{c}\text { Drop height } \\
\mathrm{mm}\end{array}$ & $\begin{array}{c}\text { Weight } \\
N \\
\end{array}$ & $\begin{array}{c}\text { Applied energy }-P 6 \\
J\end{array}$ \\
\hline 50 & 4 & 100 & 90 & 9.0 \\
\hline 100 & 4 & 100 & 90 & 9.0 \\
\hline 150 & 6 & 100 & 90 & 9.0 \\
\hline 200 & 8 & 150 & 90 & 13.5 \\
\hline 250 & 6 & 150 & 90 & 13.5 \\
\hline 300 & 8 & 200 & 90 & 18.0 \\
\hline 350 & 6 & 200 & 90 & 18.0 \\
\hline 400 & 5 & 200 & 90 & 18.0 \\
\hline 450 & 11 & 200 & 90 & 18.0 \\
\hline 500 & 8 & 200 & 90 & 18.0 \\
\hline 550 & 7 & 200 & 90 & 18.0 \\
\hline 600 & 9 & 200 & 90 & 18.0 \\
\hline 650 & 8 & 200 & 90 & 18.0 \\
\hline 700 & 8 & 200 & 90 & 18.0 \\
\hline
\end{tabular}




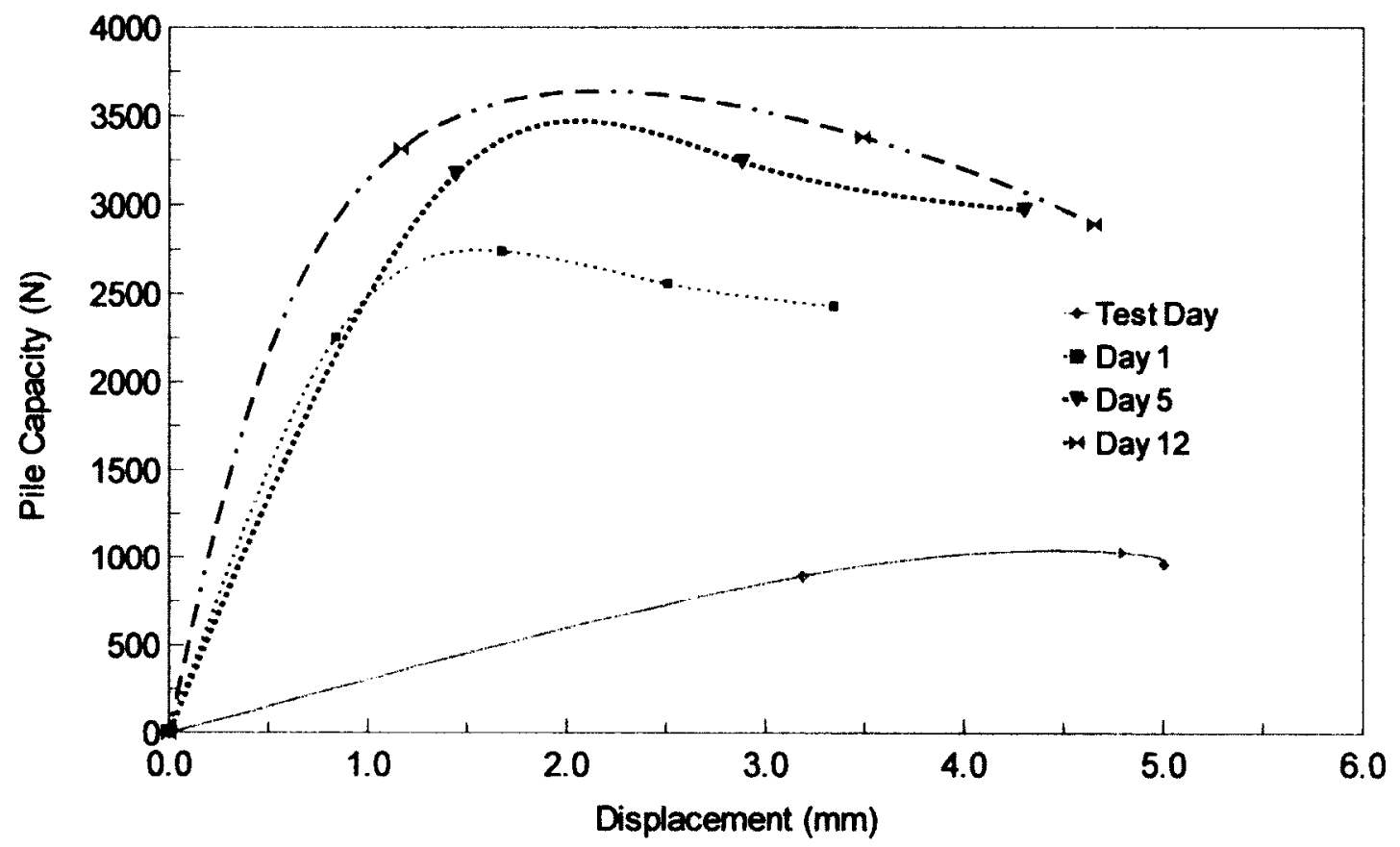

Figure 4.31: Pile capacity versus displacement for Pile 6

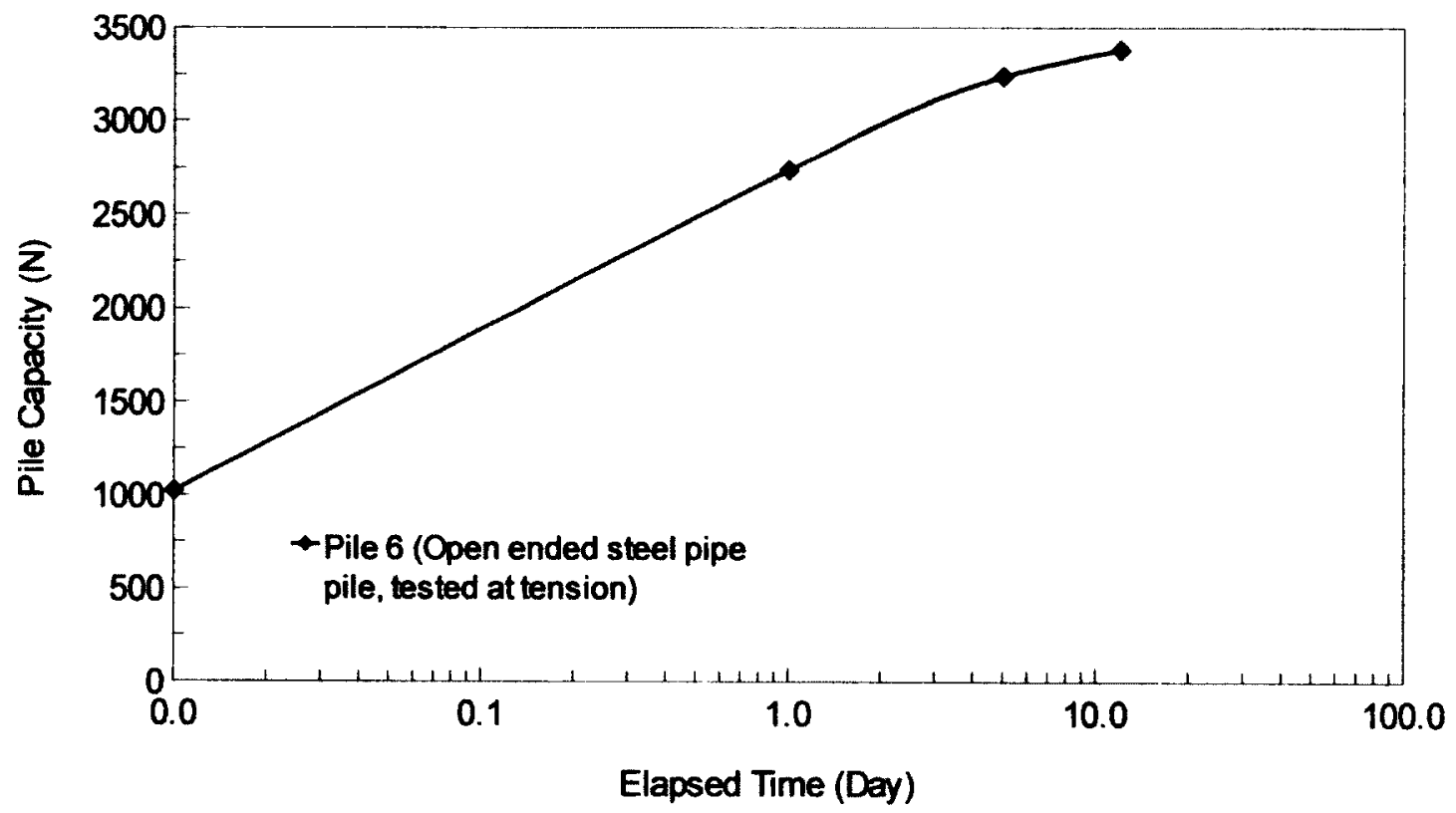

Figure 4.32: Rate of pile setup versus time for Pile 6 


\subsubsection{Pile number 7 (P7) - Field test}

In experiment 7 (P7), an open end steel pipe pile with $48 \mathrm{~mm}$ outside diameter and $3.7 \mathrm{~mm}$ wall thickness, was employed to investigate the pile setup in clay found in Geotechnical Test Site at Gloucester, ON. Leda clay layer was located at $1.5 \mathrm{~m}$ below the existing grade elevation. The clay found in this site showed similar index properties (Table 4.1), excluding undrained shear strength value which is slightly lower ( $\mathrm{Su}=30 \mathrm{kPa})$ than the clay found in Navan, $\mathrm{ON}$.

A $100 \mathrm{~mm}$ diameter hole was drilled using a gas powered augur to reach the clay layer. A $90 \mathrm{~N}$ weight with drop heights of $200 \mathrm{~mm}$ was used to drive the pile $700 \mathrm{~mm}$ below bottom elevation of the hole (Table 4.9). Figure 4.33 presents a photo of field setup. The pile was tested at tension using a hydraulic jack and a load cell immediately after driving to determine the initial pile shaft capacity. Pile load tests were also repeated 1 and 5 days after initial load test to study the evolution of the pile capacity with time. Results of this test can be compared with the piles driven into the obtained samples in the laboratory. The pile capacity was measured at $761 \mathrm{~N}$ immediately after driving and increased to $1784 \mathrm{~N}$, one day after initial pile load test (Figure 4.34). The pile capacity reached a maximum value of $2440 \mathrm{~N}$ five days after initial testing (Figure 4.35). Findings from this experiment is compared with the result of the identical test in the laboratory as discussed later. 
Table 4.9: Pile driving record for Pile 7

\begin{tabular}{|c|c|c|c|c|}
\hline \multicolumn{5}{|c|}{$\begin{array}{c}\text { (P7)Open toe steel pipe pile, tested at TENSION, Field test } \\
48 \mathrm{~mm} \text { OD, } 3.7 \mathrm{~mm} W T, 2900 \mathrm{~mm} \text { Length }\end{array}$} \\
\hline $\begin{array}{l}\text { Depth } \\
(\mathrm{mm})\end{array}$ & $\begin{array}{c}\text { Blow-count } \\
\#\end{array}$ & $\begin{array}{c}\text { Drop height } \\
\text { mm }\end{array}$ & $\begin{array}{l}\text { Weight } \\
N\end{array}$ & $\begin{array}{c}\text { Applied energy }-P 7 \\
J\end{array}$ \\
\hline 50 & 2 & 200 & 90 & 18.0 \\
\hline 100 & 2 & 200 & 90 & 18.0 \\
\hline 150 & 2 & 200 & 90 & 18.0 \\
\hline 200 & 3 & 200 & 90 & 18.0 \\
\hline 250 & 3 & 200 & 90 & 18.0 \\
\hline 300 & 3 & 200 & 90 & 18.0 \\
\hline 350 & 3 & 200 & 90 & 18.0 \\
\hline 400 & 2 & 200 & 90 & 18.0 \\
\hline 450 & 4 & 200 & 90 & 18.0 \\
\hline 500 & 4 & 200 & 90 & 18.0 \\
\hline 550 & 5 & 200 & 90 & 18.0 \\
\hline 600 & 4 & 200 & 90 & 18.0 \\
\hline 650 & 4 & 200 & 90 & 18.0 \\
\hline 700 & 4 & 200 & 90 & 18.0 \\
\hline
\end{tabular}

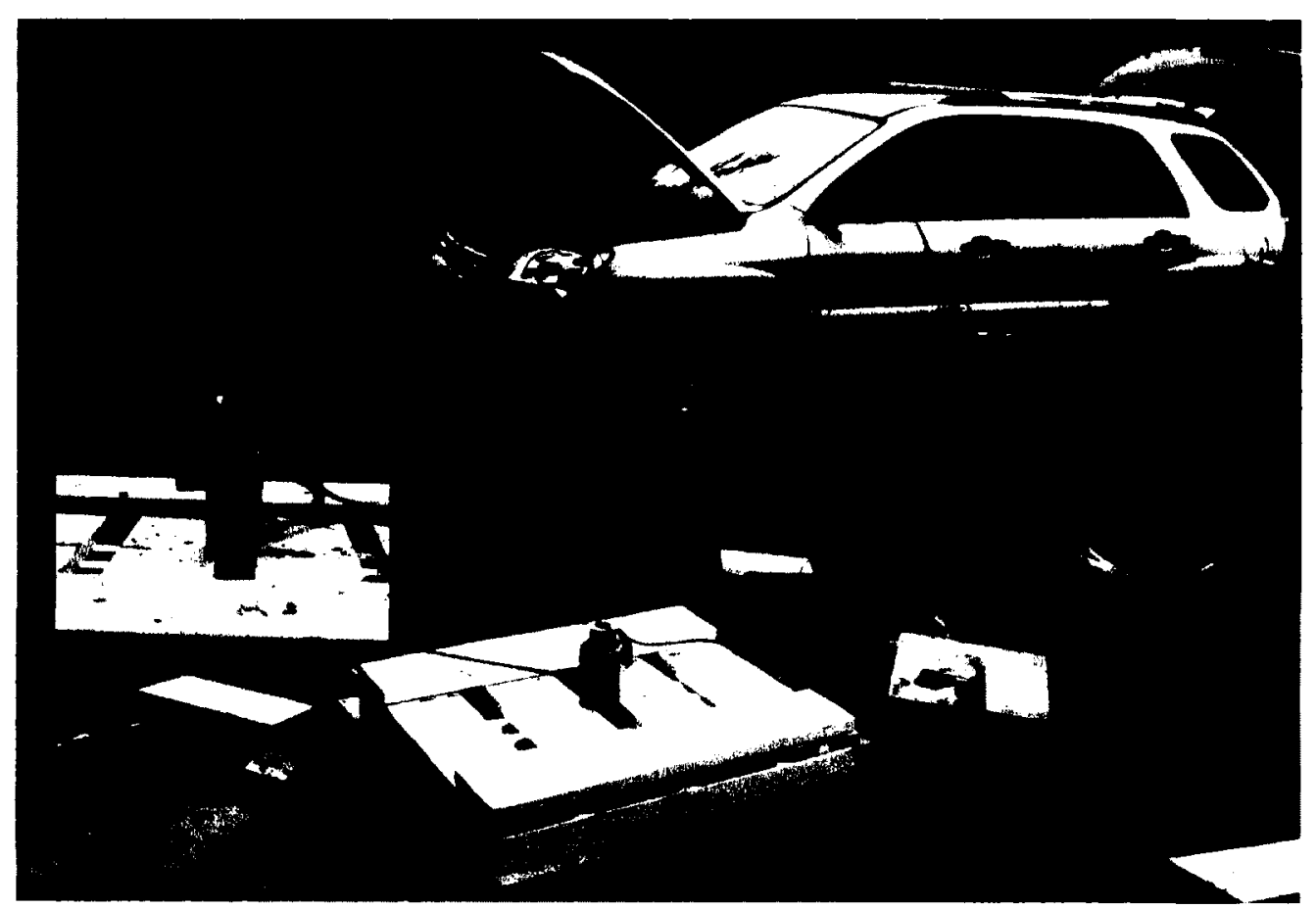

Figure 4.33: Field pile load test setup, Geotechnical Test Site, Gloucester, ON 


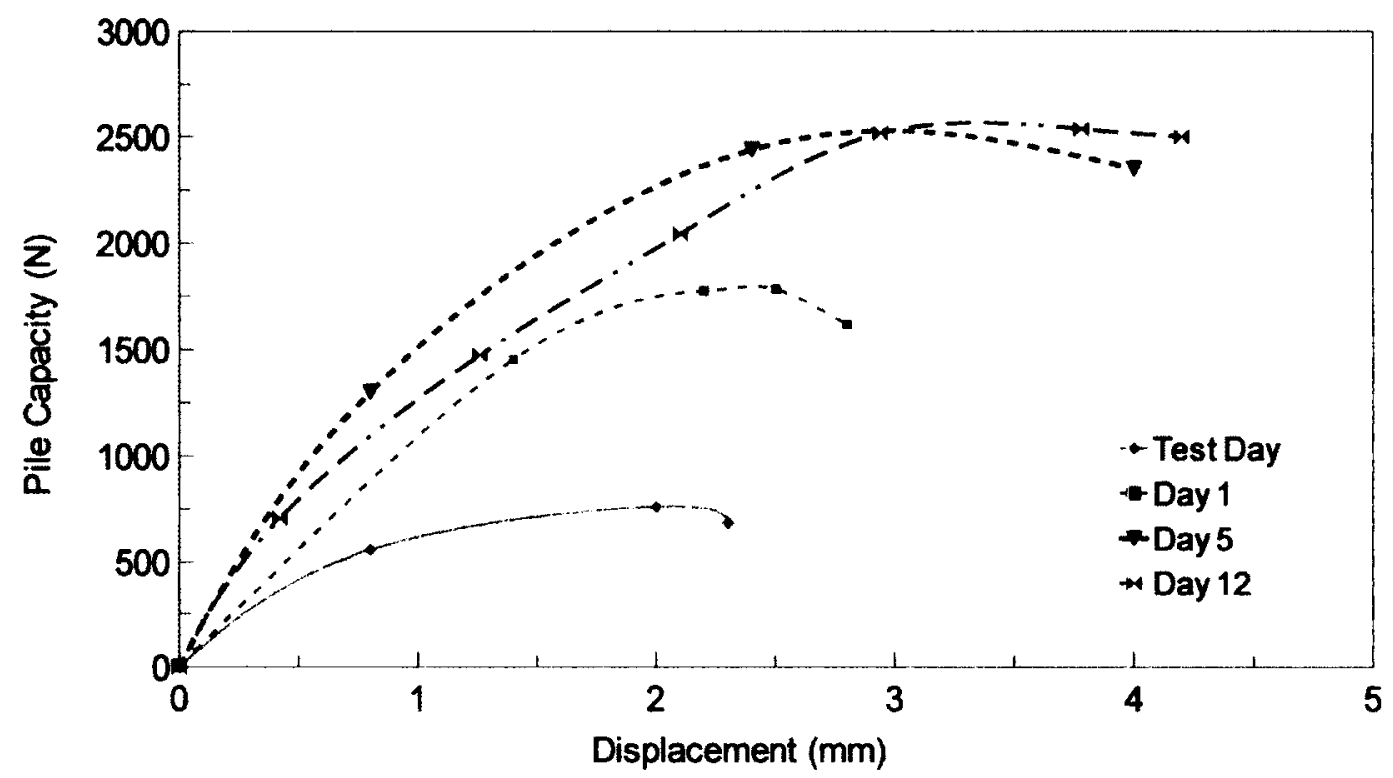

Figure 4.34: Pile capacity versus displacement for Pile 7, Field test

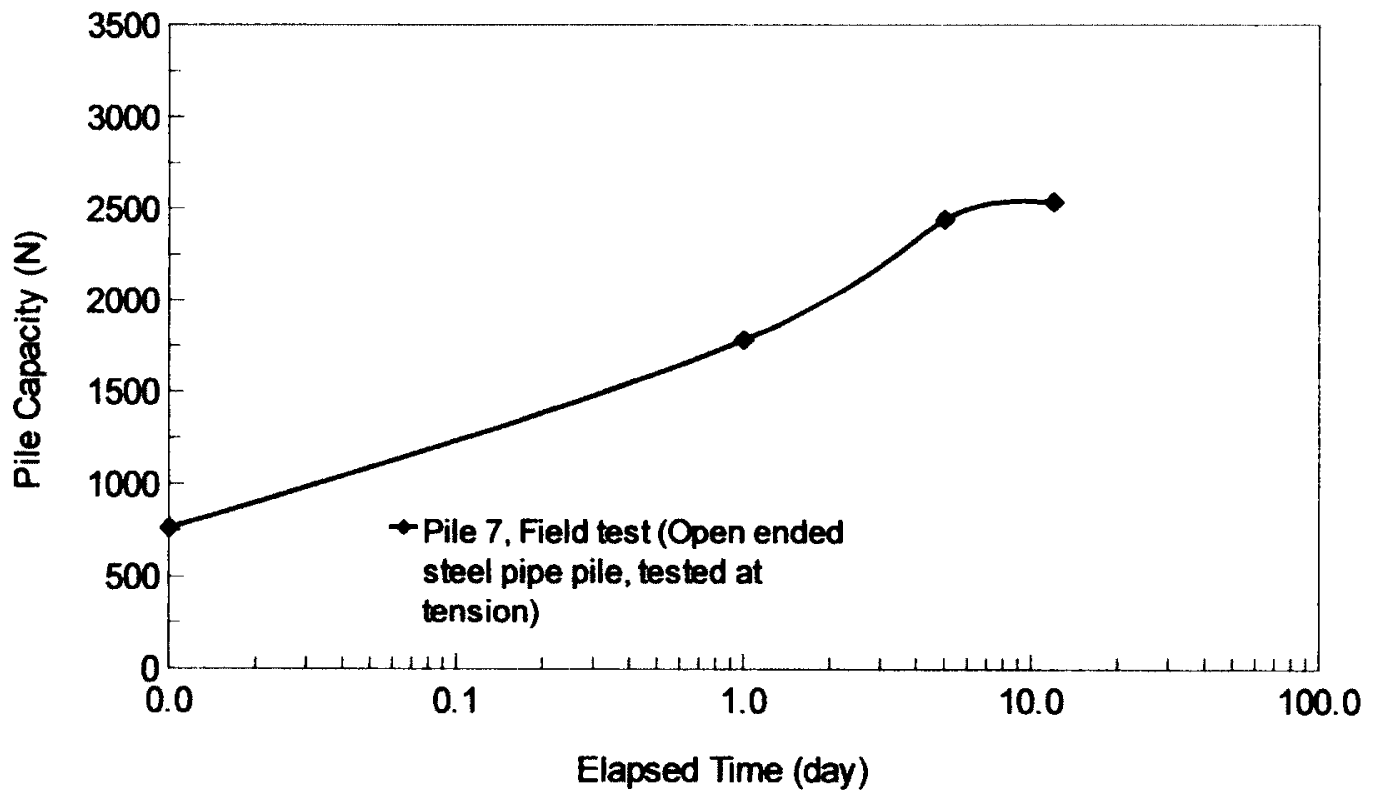

Figure 4.35: Rate of pile setup versus time for Pile 7 


\subsection{Discussion}

In order to analyze the pile setup in various test conditions, the maximum pile capacities for each test-pile were normalized by their initial pile capacities at EOID. This section tends to discuss and compare the result of performed load tests to identify the effective factors and discuss the setup rates.

\subsubsection{Effect of pile materials}

In order to assess the effect of pile materials on pile capacity increase with time, the rate of setup on concrete pile and closed end steel pipe pile was compared. The utilized concrete pile and closed end steel pipe pile can be considered identical in terms of pile geometry and the difference, solely, is in material index. Figure 4.36 illustrates setup rates versus time for concrete and closed end steel pipe pile. As shown, the rate of pile setup is greater for the concrete pile compared to the steel pile within the first day of testing. After the first day, the rate of pile capacity increase remains similar for both the concrete and steel.

This higher rate of pile setup in concrete may be induced by the type of material, as concrete has tendency of moisture absorbance compared to steel and this may produce a local bounding between the clay and the concrete pile surface. This phenomenon has also been related to a higher soil-pile interface friction. Generally, pre-stressed concrete piles have shown more capacity increase with time, compared to the steel piles (Perim et al., 1989). It should also be noted that change in pore-water salt concentration may also 
exchange phenomenon.

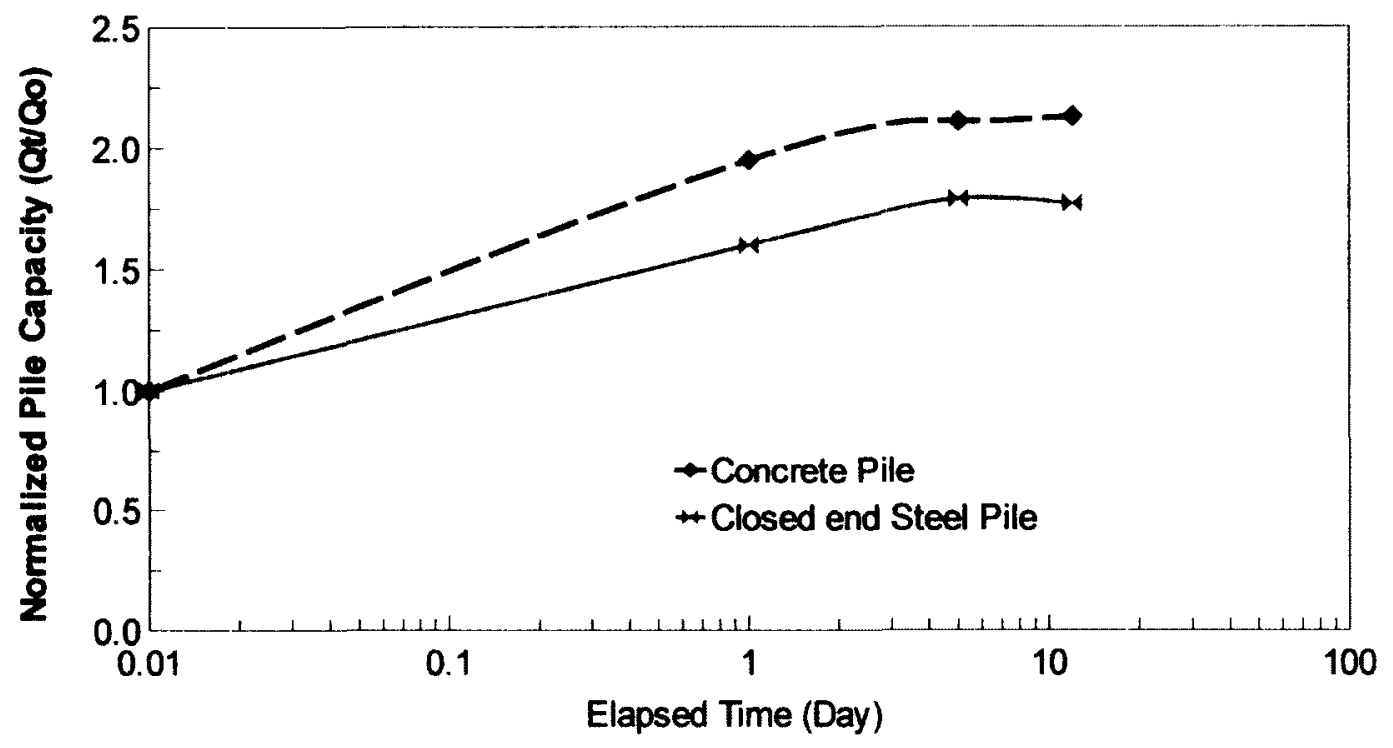

Figure 4.36: Setup rate comparison between driven concrete and steel pile

\subsubsection{Effect of pile type (Closed or open end)}

The tested piles in this experiment can be categorized in two major types of displacement and non-displacement piles. Generally, required energy to drive closed end pile is higher than the open end piles. Although in some cases different driving behaviour was observed because of developing soil plug in the open end piles, in average, the penetration resistance for closed end piles were slightly higher than the open end piles. Figure 4.37 presents penetration resistance of closed and open end piles versus depth. It should be noted that all piles were driven using same applied energy and also measured soil plug in all open end piles were approximately at equal depths.

In order to investigate effect of pile types on rate of pile setup in this experiment, 
setup rates tor each pile type has been plotted with elapsed time in Figure 4.38. As shown, the rate of pile setup for displacement piles is slightly higher than that for the nondisplacement piles. This could be attributed to the higher disturbance and hence higher excess pore water pressure during the pile driving, which leads to slightly higher setup for the close-end pile. However, this difference in pile setup was not very significant.

It should be noted, in average, the actual magnitude of measured pile capacity for open end piles was slightly higher than the close end steel pile (for example P2 vs. P5). Therefore, considering the higher initial capacity of the open end piles as well as the relatively similar setup, the open end piles would be a preferred option for soft clays like marine Leda clay.

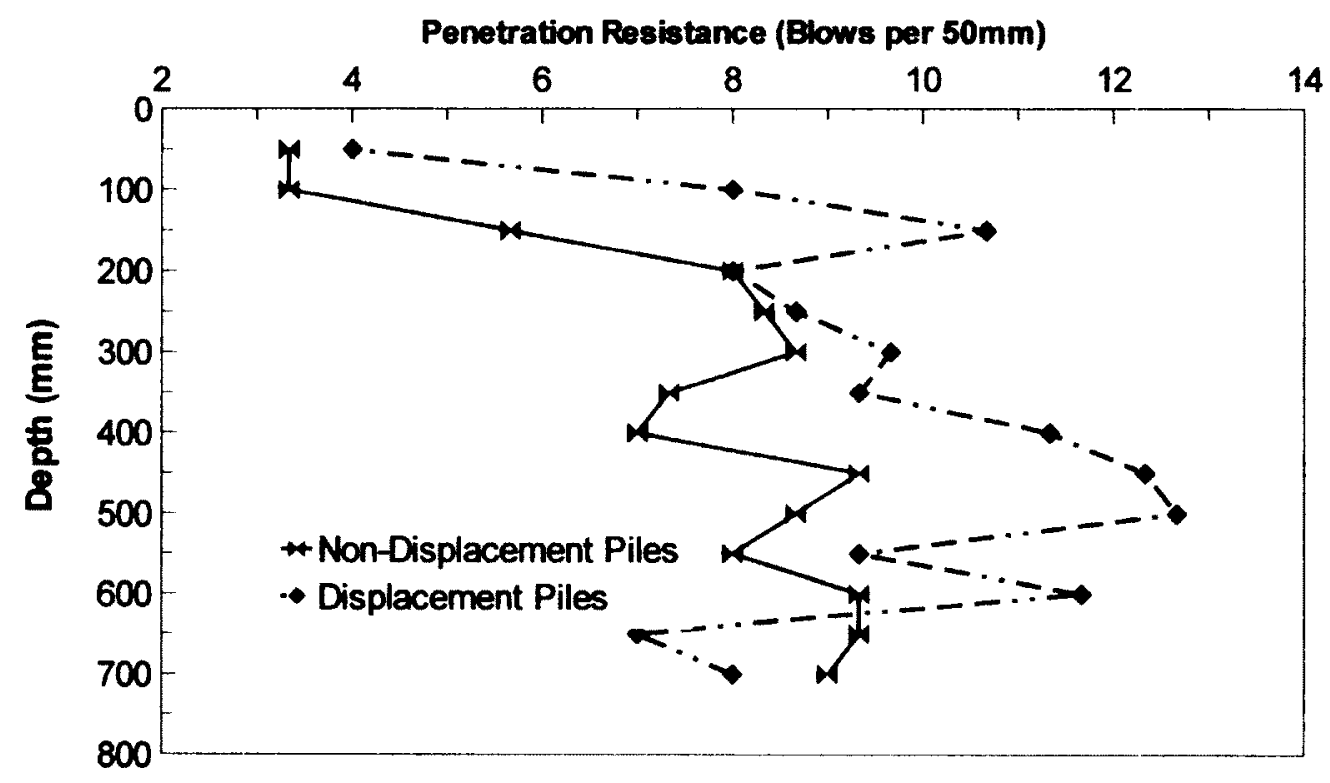

Figure 4.37: Penetration resistance comparison, Between non-displacement piles and displacement piles 


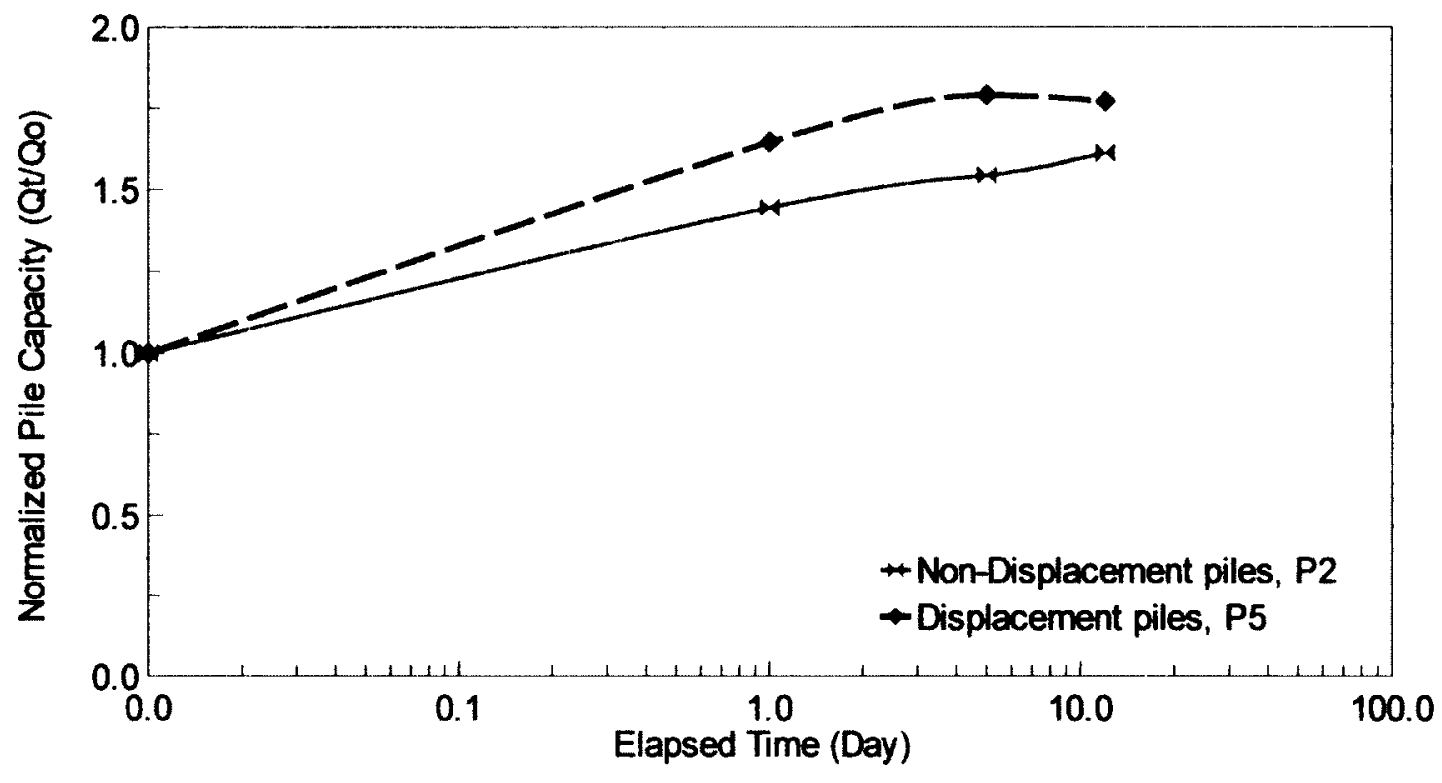

Figure 4.38: Setup rate comparison between displacement and non-displacement piles

\subsubsection{Magnitude of pile setup}

According to the pile load test results performed in Leda clay, an average setup rate of 2.0 was observed, 12 days after initial pile driving. This rate was fluctuated based on different influential parameters, such as type of pile and type of loading (Figure 4.39). The minimum and maximum setup values recorded in this study were 1.6 and 3.3 , respectively which were observed 12 days after pile driving. 


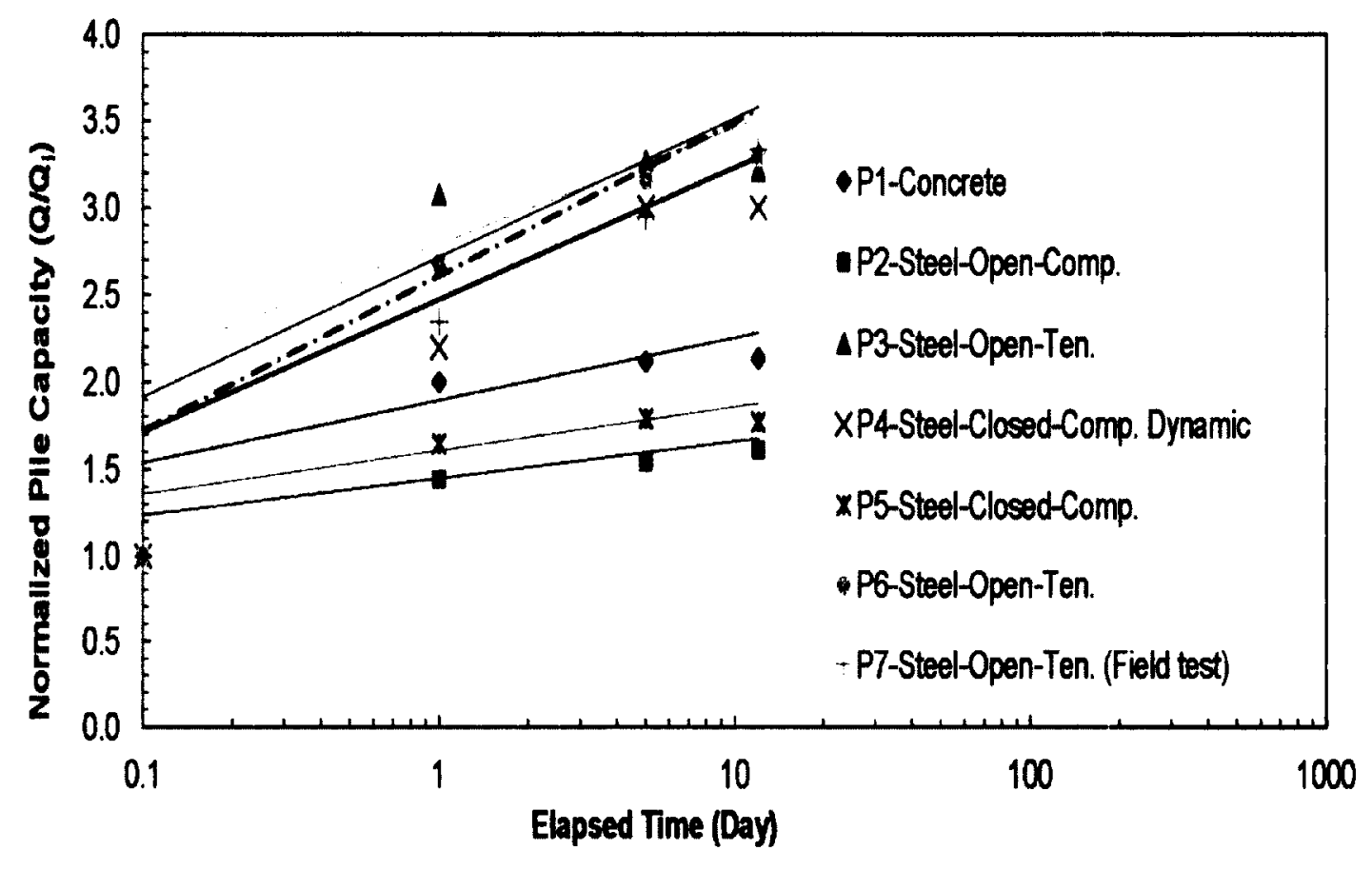

Figure 4.39: Pile setup data for all the experiments tested

As noted earlier, a number of empirical equations have also been proposed to quantify the magnitude of pile setup. Skov and Denver (1988) proposed a formula to estimate the pile capacity $\left(Q_{t}\right)$ at different elapse time $(t)$ from the pile capacity at EOID $\left(Q_{0}\right):$

$$
Q_{t}=Q_{0}\left\lfloor 1+\operatorname{Alog}\left(\frac{t}{t_{0}}\right)\right\rfloor
$$

where $A$ and $t_{0}$ are empirical parameters which depend on the soil type. Skov and Denver (1988) suggested a setup value of $A=0.6$ and $\mathrm{t}_{0}=1$ day for clayey soils, based on two case histories of 13 driven concrete piles and 21 load test data.

This equation is adopted here to estimate the $A$ value used in this equation for Leda clay. Based on limited data driven from this study (Figure 4.39), an optimum setup 
parameter, $A=0.5-2.0$, was suggested for the marine clay in this formula. Total pile capacity at different elapsed times considering pile setup can be estimated using this value and Equation 4.1. In this approach, $Q_{0}$ can be estimated from the pile shaft $\left(Q_{s}\right)$ and toe $\left(Q_{t}\right)$ capacities at EOID using the method of Alawneh et al. (2001) as follow:

$$
Q_{0}=Q_{s}+Q_{t}
$$

This approach can be used as a design method to consider the pile setup in pile foundation design, which may lead to a considerable saving in pile foundation cost. For example, considering an average setup factor of 1.25 (A), the final bearing capacity of a pile with initial capacity of $100 \mathrm{kN}$ could be as high as $240 \mathrm{kN}$ two weeks after initial driving. The number of piles as well as pile length, diameter and driving energy may be reduced if the increase in pile capacity with time is considered in design.

\subsubsection{Pile setup duration}

According to the load test results on medium scale piles, majority of pile setup has been observed within 24 hours after pile driving which is in correspond to the recorded pore water pressure dissipation. After day 1, the excess pore water pressure dropped and hence the rate of pile setup was reduced significantly.

The time required for dissipation of excess pore water pressure, and hence the capacity increase, can be estimated using Terzaghi's theory for one-dimensional consolidation: 


$$
T=\frac{c_{v} t}{H_{d r^{2}}}
$$

where $T$ is the time factor, $t$ is the time of consolidation, $c_{v}$ is the consolidation coefficient of the soil (Table 4.1), and $H_{d r}$ is the length of the drainage path perpendicular to the pile axes. The drainage length can be assumed as the width of the disturbed zone around the pile. This drainage length for the pile-soil system can be obtained from the theory of cavity expansion in elasto-plastic media. The distribution of initial excess pore water pressure outward the pile can be predicted using the undrained shear strength and the shear modulus of the soil, (Randolph et al., 1979). The excess pore pressure varies along the disturbed zone, showing a maximum at the pile surface and zero at $H_{d r}$ (Leifer et al., 1979). Using this simple expression, the time required for the disturbed zone to consolidate can be estimated assuming that the excess pore water pressure is uniformly distributed within the disturbed area.

\subsubsection{Comparison with field test result}

As mentioned earlier, a series of pile load tests on an identical lab specimen (P7) were conducted in the field to compare the results with the measured pile setup on the undisturbed clay sample in laboratory condition and also check the boundary conditions.

Results obtained from the field tests were plotted in Figure 4.40 along with one measured on the identical pile in lab. In general, both piles achieved similar rate of setup in the two testing conditions. This confirms that the boundary conditions used in this 
experiment simulated the field conditions and the effect of the container boundary on the test results is negligible. A slight difference in the rate of setup between the field and laboratory experiment could be due to the difference in overburden pressure and state of stress in both experiments. As far as the actual magnitude of pile setup, filed test pile (P7) has experienced slightly lower capacity throughout the testing (presented in Table 4.2) in comparison with lab. This could be due to the lower undrained shear strength of the soil in the field $\left(\mathrm{S}_{\mathrm{u}}=30 \mathrm{kPa}\right)$ compared with the undrained shear strength of $50 \mathrm{kPa}$ for the clay obtained for laboratory tests.

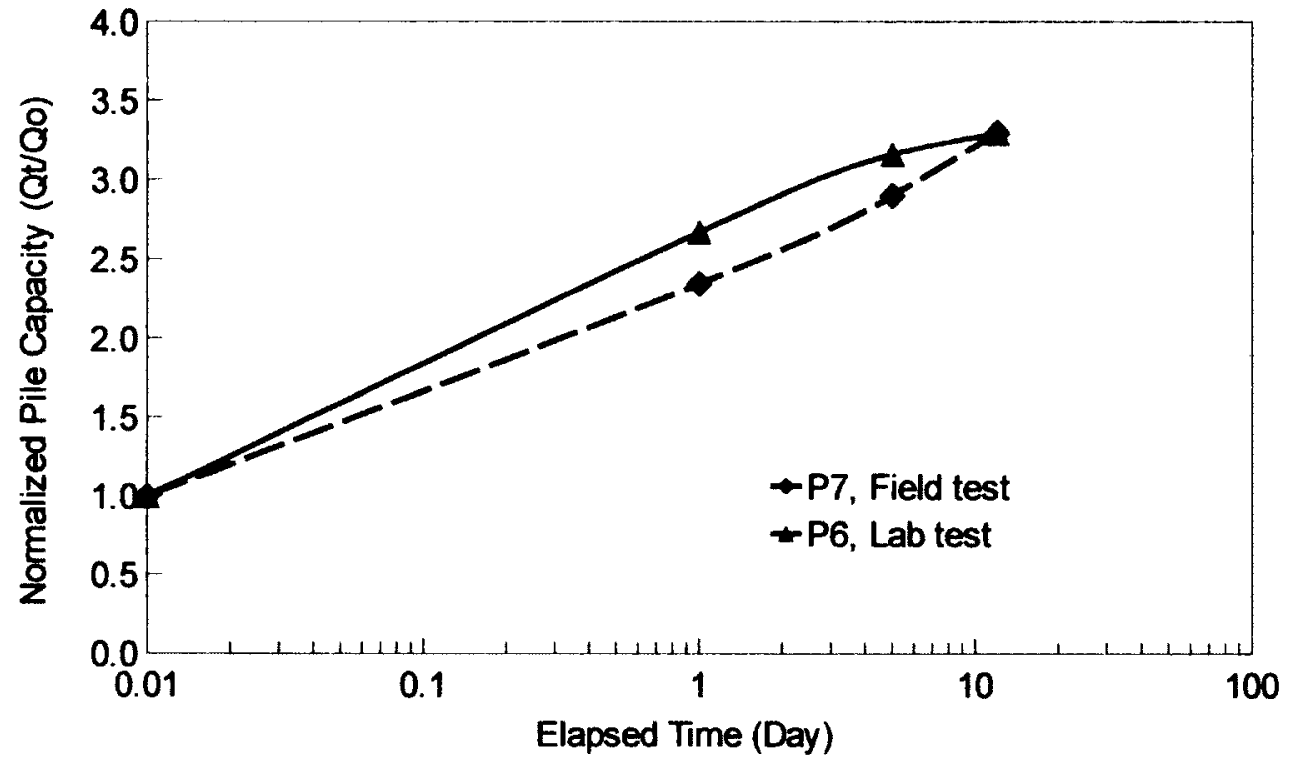

Figure 4.40: Pile setup comparison between field test and laboratory test 


\subsubsection{Comparison with previous studies}

As mentioned in Chapter 2, pile setup phenomenon has been studied by many researchers and various ranges of pile setup have been reported for driven piles in clay-water system. An investigation in southeast Louisiana presented approximately 400 to $500 \%$ increase in pile shaft capacity after few weeks of driving (Blessey and Lee, 1980). Another research on prototype scale piles in New Orleans presented 440 to $1150 \%$ pile capacity setup (Mc Manins et al., 1988). Also Denver and Skov (1988) reported a pile capacity increase of 20 to $100 \%$. Bartolomey and Yushkov (1985) observed 70 to $80 \%$ increase in soil shear strength, 45 days after initial drive. A capacity increase of $25 \%$ was reported for piles driven into stiff Chicago clay and 50\% for piles driven into soft Chicago clay within 10 to 32 days (Lulas and Bushell, 1989). Afterwards, a range of 25 to $1140 \%$ in a time frame of 2 days to 3 months has been observed as pile setup on different type of piles in different locations.

In this section the average pile setup measured during this study is compared with those proposed for piles driven in clay (Figure 4.41). In comparison with previous research, the setup presented in this study, for small scale driven pile into Leda clay, exhibits a slightly higher rate of pile setup in a shorter period of time. However the maximum setup rate is similar with those proposed in literature. The higher setup rate in a faster manner can be related to the type of clay, its shear strength and water content (Table 4.1). Also small scaling may have shortened the reconsolidation and pore water dissipation time. Medium scaled piles were retained in this study causes less disturbance and deformation compared with prototype piles due to their diameter. 


\subsubsection{Comparison the measured pile capacity with static analysis ( $\alpha$-Method)}

The $\alpha$-Method is normally used to estimate the short-term pile capacity and is based on total stress analysis. The pile shaft capacity $\left(Q_{s}\right)$ can be calculated by:

$$
Q_{s}=\alpha_{u} S_{u} \pi D L
$$

where $\alpha_{u}$ is the skin friction factor, $S_{u}$ is undrained shear strength, $\mathrm{D}$ is the pile diameter and $\mathrm{L}$ is the pile embedment. As $S_{u}=50 \mathrm{kPa}$ for the clay obtained for laboratory tests and $S_{u}=30 \mathrm{kPa}$ for the clay in the field test (P7), $\alpha_{u}$ is calculated as 0.72 and 0.94 , respectively (API, 1984). The outside diameter (D) and pile embedment (L) are $0.048 \mathrm{~m}$ and $0.7 \mathrm{~m}$, respectively. Thus, pile shaft capacity for piles driven in laboratory tests is calculated at $3800 \mathrm{~N}$ and for the pile driven into the field is calculated at $2976 \mathrm{~N}$. Figure 4.42, illustrates the measured pile capacity of open ended steel piles which is tested in tension and also presents the calculated pile capacity using $\alpha$-Method. The measured pile capacities are much lower than that calculated for friction piles in Leda clay. This could be explained by the sensitivity of the clay as well as the excess pore water pressure generated at the time of driving. 


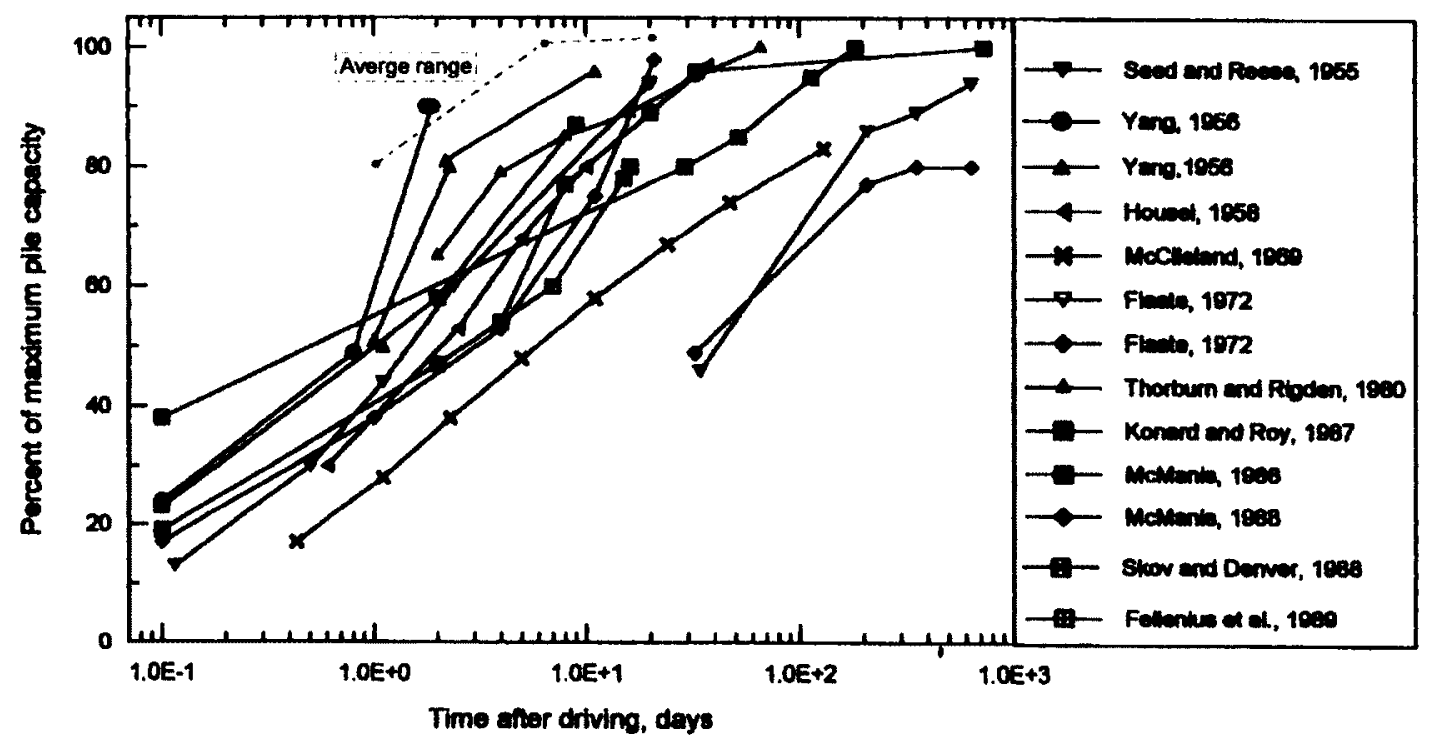

Figure 4.41: Pile bearing capacity increase with time for piles driven into clay. Date from experiment has been illustrated as dash-line. (modified from Titi, 1996)

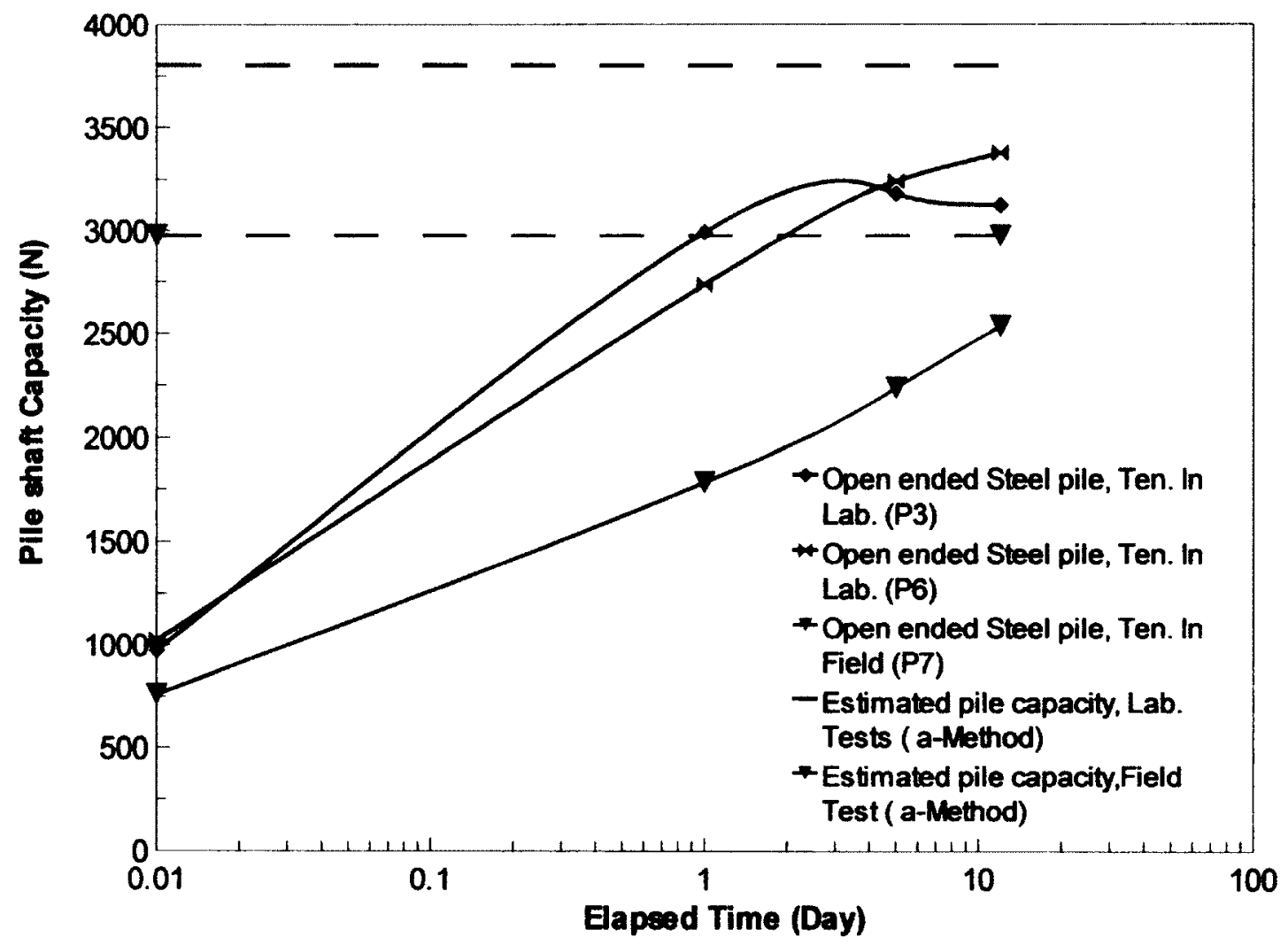

Figure 4.42: Pile capacity comparison, measured and calculated 


\subsection{Summary}

A total of seven piles were driven into the Leda clay to the depth of $700 \mathrm{~mm}$ below surface, to study the effect of time on pile capacity increase. Piles were selected in different materials (concrete and steel), types (displacement and non-displacement) and tested under various conditions (tension/compression, static/dynamic) to extend the study to most possible situations in prototype scale. Six piles were driven in undisturbed sample in laboratory environment and one pile was driven into Leda clay in the field. All piles were tested immediately after driving and repeated 1,5 and 12 days after initial driving. Pore water pressure was monitored on a number of piles during driving as well as throughout the test.

In average, displacement piles presented a slight higher pile setup rate compared to the non-displacement piles, as displacement piles cause a larger soil displacement and more excess pore water pressures. Also the concrete pile showed a higher pile setup in comparison with the steel. This can be explained by providing a better bounding between clay and concrete induced by moisture absorbance of the concrete surface.

All piles were experienced a setup rate of 1.6 to 3.3 , in relation with their initial capacities, 12 days after driving. Most of the measured pile setup was generated within the first day period due to the higher rate of pore water pressure dissipation. After the first day, the rate of pile setup was decreased. Similar behaviour was observed on pore water pressure as the rate of decrease in pore pressure was also negligible. 


\section{CHAPTER :5 CONCLUSIONS AND RECOMMENDATION}

\subsection{Conclusions}

In this research, evolution of pile capacity with elapsed time for driven piles into the soft and sensitive clay has been investigated in two stages. In phase one, characteristics of stress-strain and frictional behaviour of pile-soil interface (steel-soil and concrete-soil) in different time was investigated on a type of soft clay, obtained from south of Winnipeg, MB. In phase two, medium scale load testing was performed on piles driven into the obtained undisturbed Leda clay samples. From the evaluation of results, following conclusions are terminated:

1) The interface strength for both concrete- and steel-soil systems increased as the consolidation time after the initial shear tests increased up to 12 days for the south Manitoba clay. The maximum increase in interface strength varied from $20-80 \%$ of the initial shear strength, depend on the normal stresses applied. These results are in general agreement with fundamental observations on the time-dependent strength of soils which is related, at least in part, to dissipation of excess pore water pressure in the interface zone. The rate of strength increase was shown to be similar in both steel and concrete surfaces, although the specific strength values for concrete piles are higher than those measured in steel piles. 
2) All medium scaled piles driven into Leda clay, experienced $60 \%$ to $230 \%$ increase in pile capacity in comparison with the initial capacity, within 12 days after driving. The obtained pile setup magnitude is in general agreement with previous studies, but 12 days may not be a sufficient time for prototype piles to regain the pile capacity.

3) Both non-displacement and displacement piles showed a similar rate of pile setup. As non-displacement piles are slightly less expensive, need less effort to reach the desire depth, and provide a higher initial pile capacity, they could be considered as a more preferable option for pile driving in Clay. As Leda clay turns from solid state to the semi-liquid state when disturbed, using non-displacement piles would also be safer, as less disturbance and vibration is produced and they are penetrated.

4) Concrete pile presented a higher rate of pile setup, in comparison with steel piles, as concrete generated a better interface bounding with clay. As concrete piles are more economical, utilizing this type of pile may lead to cost effective design.

\subsection{Recommendations for future work}

Results presented here are based on limited number of pile load tests. More detailed pile load tests would provide better understanding of pile behaviour in soft clay. It could also be beneficial to perform load tests on non-displacement concrete piles. This type of pile is utilized in industry and as known as ICP-PHC pile (Industrial Concrete Production Pretensioned Spun High Strength Concrete piles) which is a semi-Hollow section. Also, the percentage of Clay salinity may influence the rate of pile setup, especially in case of concrete piles in longer time frame and can define a different ageing progress. Effect of 
disturbance and vibration induced by pile driving in Leda clay can lead to an earth-flow event or at least a pile capacity lost effect. Investigation of this phenomenon seems to be very beneficial.

In industry, one of the major costs of prototype load testing is mobilizing and demobilizing the heavy equipment and material. This study proposes a simpler type of load testing, which is driving scaled piles into the future project location and performing load testing on piles in different time frame. The scaled testing may not provide a straight forward relation to the full scale pile, but it would present better information on pile capacity, especially shaft friction capacity and rate of pile setup. 


\section{REFERENCES}

- Alawneh, A.S., Nusir, O., Malkawi, A.I.H., and Al-Kateeb, M., 2001. Axial compressive capacity of driven piles in sand, a method including post-driving residual stress. Canadian Geotechnical Journal, 38: 364-377

- Altaee, A. \& Fellenius, B.H., 1994. Physical modeling in sand, Can. Geotechnical J. No. $31,420-431$.

- Appolonia, D.J., 1971. Effects of foundation construction on nearby structures. Proc. of $4^{\text {th }}$ Panamerican Conf. on Soil Mechanics and Foundation Eng., Puerto Rico, pp 189-235.

- ASTM D 1143. 2008. Standard test methods for static pile load tests. ASTM Standard 04.08, ASTM, West Conshohocken, PA, USA.

- ASTM D 2435. 2008. Standard test methods for one-dimensional consolidation properties of soils. ASTM Standard 04.08, ASTM, West Conshohocken, PA, USA.

- ASTM D 2487. 2008. Standard Practice for Classification of Soils for Engineering Purposes (Unified Soil Classification System), ASTM Standard 04.08, ASTM, West Conshohocken, PA, USA: 249-260.

- ASTM D 2573. 2008. Standard test methods for field vane shear test in cohesive soils. ASTM Standard 04.08, ASTM, West Conshohocken, PA, USA. 
- ASTM D 422. 2008. Standard test method for particle size analysis of soils, ASTM Standard 04.08, ASTM, West Conshohocken, PA, USA: 10-17.

- ASTM D 4318. 2008. Standard Test Method for Liquid Limit, Plastic Limit, and Plasticity Index of Soils, ASTM Standard 04.08, ASTM, West Conshohocken, PA, USA: $1-13$.

- ASTM D 698. 2008. Standard test methods for laboratory compaction characteristics on soil using standard effort, ASTM Standard 04.08, ASTM, West Conshohocken, PA, USA: 80-90.

- ASTM D2216. 2008. Standard test methods for laboratory determination of water (moisture) content of soil and rock by mass, ASTM Standard 04.08, ASTM, West Conshohocken, PA, USA.

- ASTM D-3080. 2008. Standard test method for direct shear test of soil under consolidated drained conditions, ASTM Standard 04.08, ASTM, West Conshohocken, PA, USA.

- ASTM D-4945. 2008. Standard test method for high-strain dynamic testing of piles, ASTM Standard 04.08, ASTM, West Conshohocken, PA, USA.

- ASTM D5321. 2008. Standard test method for determining the coefficient of soil and geosynthetic or geosynthetic and geosynthetic friction by direct shear method, ASTM Standard 04.08, ASTM, West Conshohocken, PA, USA. 
- Axelsson, G., 1998. Long-term setup of driven piles in non-cohesive soils. Licentiate Thesis, Royal Institute of Technology, Stockholm.

- Axelsson, G., 2002. A conceptual model of pile setup for driven piles in noncohesive soil. GSP 116, ASCE, 64-79

- Azzonz, A. S., and Luts, D. G., 1986. Shaft behavior of a model pile in plastic Empire clay. Journal of Geotechnical Engineering, ASCE, Vol. 112, No. GT4, pp 389-406.

- Azzouz, A. S., and Baligh, M. M. ,1984. Behavior of friction piles in plastic Empire Clays. MIT Research Report, MA.

- Azzouz, A. S., Baligh, M. M., and Whittle, A. J., 1990. Shaft resistance of pile in clay. Journal of Geotechnical Engineering, ASCE, Vol. 116, No. GT2, pp 205-221.

- Baligh, M. M., 1975. Theory of deep site static cone penetration resistance. Research Report No. R75-56, Department of Civil Engineering, MIT, Cambridge, Massachusetts, $133 \mathrm{p}$.

- Baligh, M. M., 1984. Simple pile approach to pile installation in clays. Analysis and Design of Pile Foundations, J. R. Meyer, (Editor), pp 310-330.

- Baligh, M. M., 1985. Strain path method. Journal of Geotechnical Engineering, ASCE, Vol. 111, No. GT7, pp 1108-1196.

- Baligh, M. M., 1986. Undrained deep penetration, II: Pore Pressures. Geotechnique, Vol. 36, No. 4, pp 487-501. 
- Baligh, M. M., and Levadoux N., J., 1980. Pore pressure dissipation after cone penetration. Report No. MITSG 80-13, MIT, Cambridge, Massachusetts, 310 pp.

- Banerjee, P. K., Davies, T. G., and Fathallah, R. C., 1982. Behavior of axially loaded driven piles in saturated Clay from Model Studies. Chapter 5 in Developments in Soil Mechanics and Foundation Engineering, Edited by P. K. Banerjee. Applied Science Publishers Ltd., England.

- Barland, J., 1973. Shaft friction of piles in clay a simple fundamental approach. Proc., Ground Engineering, 6(3), pp 48-51.

- Bartolomy, A. A. and Yushkov, B. S., 1985. Variation in time of capacity of pile foundations in clay. Proc. 11th Int. Conf. of Soil Mech. and Found. Eng., San Francisco, pp 1517-1520.

- Bjerrnm, L., Brinch Hansen, J., and Sevaldson, R., 1958. Geotechnical investigation for a quay structure in Horten. NGI, No. 28, 1-17.

- Blessey, W.E., and Lee, P.Y., 1980. Report on Wave Equation Analysis of pile driving in the New Orleans area. Pile Driving Contractors Association of New Orleans Inc.

- Bogard, J. D., and Matlock, H., 1979. A model study of axially loaded pile segments, including pore pressure measurements. Report to the American Petroleum Institute, Austin, Texas. 
- Bogard, J. D., and Matlock, H., 1990. Application to model pile tests to axial pile design. Proceedings, Offshore Technology Conference, Paper 6376, Houston, Texas, USA.

- Bogard, J. D., and Matlock, H., 1990a. In-situ pile segment model experiments at Empire, Louisiana. Proceedings, Offshore Technology Conference, Paper 6323, Houston, Texas, USA.

- Bogard, J. D., and Matlock, H., 1990b. In-situ pile segment model experiments at Harvey, Louisiana. Proceedings, Offshore Technology Conference, Paper 6324, Houston, Texas, USA.

- Bond, A. J., and Jardine, R. J., 1991. Effects of installing displacement piles in a high OCR clay. Geotechnique, Vol. 41, No. 3, pp 341-363.

- Bozozuk, M., Fellenius, B. H., and Samson, L., 1978. Soil disturbance from Pile Driving in sensitive clay. Canadian Geotechnical Journal, Vol 15, pp 346-361.

- Bullock, P.J., 1999. Pile friction freeze; A field and laboratory study, vol. 1. Ph.D. Dissertation, University of Florida.

- Burland, J., 1973. Shaft friction of piles in clay a simple fundamental approach. Proc., Ground Engineering, 6(3), pp 48-51.

- Camp III, W.M. And Parmar, H. S., 1999. Characterization of pile capacity with time in the Cooper Marl: A study of the applicability of a past approach to predict long-term pile capacity. Emre, TRB, pp 1-19. 
- Carter, J. P., Randolph, M. F., and Wroth, C. P., 1979. Stress and pore pressure changes in clay during and after the expansion of the of a cylindrical cavity. International Journal for Numerical and Analytical Methods in Geomechanics, Vol. 3, pp 305-322.

- Carter, J. P., Randolph, M.F., and Worth, C.P., 1980. Some aspects of the performance of open- and closed end piles. Numerical methods in offshore piling, London, 1980, pp. 1650170.

- Chandler, R. J., 1968. The shaft friction of piles in cohesive soils in terms of effective stresses. Civil Engineering and Public Works Review, 63, pp 48- 51.

- Chow, Y. K., Karunaratne, G. P., Wong, K. Y., and Lee, S. L., 1988. Prediction of load carrying capacity of driven piles. Canadian Geotechnical Journal, Vol. 25, pp $13-25$.

- Chung, K. Y. C., 1988. Excess pore pressure induced by pile driving in sensitive river sediment. Proceedings, 3rd. Int. Seminar on the Application of Stress-Wave Theory to Piles, Ottawa, B. H. Fellenius, Ed., pp 679-888.

- Clark, J. I., and Meyerhof, G. G., 1972. The behavior of piles driven in clay. I. An investigation of soil stress and pore water pressure as related to soil properties. Canadian Geotechnical Journal, Vol. 9, pp 351-373.

- Clark, J. I., and Meyerhof, G. G., 1973. The Behavior of Piles Driven in Clay II. Investigation of the bearing capacity using total and effective strength parameters. Canadian Geotechnical Journal, Vol. 10, pp 86-102. 
- Cooke, R. W., and Price, G., 1973. Strains and displacements around friction piles. Proceedings, 8th ICSMFE, Moscow, Vol. 2, No. 1, pp 53-60.

- Coop, M. R, and Wroth, C. P., 1989. field studies of an instrumented model pile in clay. Geotechnique, Vol. 39, No. 4, pp 679-696.

- Cummings, A. E., Kerkhoff, G. O., and Peck, R. B., 1950. Effect of pile driving in soft clay. Trans. ASCE, Vol. 115, 275-286.

- D' Appolonia, D. J. and Lambe, T. W., 1971. Performance of four foundation on end-bearing piles,. JSMFD, ASCE, 97(10), 1359-1377.

- De Mello, V. F. B., 1969. Foundations of buildings on clay. State-of-the-Art report. Proc. 7th ICSMFE, 49-136.

- Dusseault M.B. and Morgenstern N.R., 1979. Locked sand. Q. J. Engng. Geol., Vol.12 pp. 117-131.

- Eide, O., Hutchinson, J. N., and Landva, A., 1961. Short and long-term test loading of a friction pile in clay. Proc. 5th Int. Conf. of Soil Mech. and Found. Eng., pp 45-54, Paris.

- Esrig, M. I., Kirby, R. C., Bea, R. G., and Murphy, B. S., 1977. Initial development of a general effective stress method for the prediction of axial capacity of piles in clay. Proceedings, Offshore Technology Conference, Houston, Texas, USA. 
- Fellenius, B. H., and Samson, L, 1976. Testing of drivability of concrete piles and disturbance to sensitive clay. Canadian Geotechnical Journal, Vol 13, pp 139-160.

- Fellenius, B. H., Riker, R. E., O'Brien, J. A., and Tracy, G. R., 1989. Dynamic and static testing in soils Exhibiting setup. Journal of Geotechnical Engineering, ASCE, Vol. 115, No. GT7, pp 984-1001.

- Finno, R. 1989. Predicted and observed axial behavior of piles. Geotechnical Special Publication No. 23, ASCE.

- Fioravante V., 2002. On the shaft friction modeling of non-displacement piles in sand. Soils and Foundations, 42(2):23-33.

- Flaate, K., 1968. The bearing capacity of friction piles in clay (in Norwegian). Norw. Road Res. Lab., Oslo, 38 p.

- Flaate, K., 1972. Effects of pile driving on clays. Canadian Geotechnical Journal, Vol. 9, pp 81-88.

- Flaate, K., and Selnes P., 1977. Side friction of piles in clay. Proc. $9^{\text {th }}$ Int. Conf. on Soil Mechanics and Foundation Engineering, Tokyo, Japan, Vol. 1, pp 517-522.

- Goldstein, M.N., Misumsky, V.A., and Lapidus, L.S., 1961. The theory of probability and statistics in relation to the rheology of soils. Proc., $5^{\text {th }}$ Int. Conf. Soil Mechanics, Paris, 1 : pp. 123-126. 
- Guang-Yu, Z., 1988. Wave equation applications for piles in soft ground. Proc., $3^{\text {rd }}$ International Conference on the Application of Stress-Wave Theory to Piles (B. H. Fellenius, ed.), Ottawa, Ontario, Canada, pp. 831-836.

- Housel, W. S., and Burkey, J. R., 1948. Investigation to determine the driving characteristics of piles in soft clay. Proc. 2nd ICSMFE, Vol. 5, 146-154.

- Huang, S., 1988. Application of dynamic measurement on long H-Pile driven into soft ground in Shanghai. Proc., $3^{\text {rd }}$ International Conference on the Application of Stress-Wave Theory to Piles (B. H. Fellenius, ed.), Ottawa, Ontario, Canada, pp. 635643.

- Karlsrud, K. and T. Haugen. 1991. Axial static capacity of steel model piles in overconsolidated clay. Bulletin No. 163, Norwegian Geotechnical Institute, Oslo, Norway, p. 3.

- Kirby, R.C., and Wroth, C. P., 1977. Applications of critical state soil mechanics to the prediction of axial capacity for driven piles in clay. Offshore Technology Conference, Houston, Texas , Paper No. 2942.

- Ko, H.Y., Atkinson, R.H., Goble, G.G., \& Ealy, C.D., 1984. Centrifugal modeling of pile foundations. J.R. Meyer (Ed.), Analysis and Design of Pile Foundations. Reston, VA: ASCE, 21-40.

- Koizumi, Y., and Ito, K., 1967. Field tests with regard to pile driving and bearing capacity of piled foundation. Soil and Found., VII (3), pp 30-53. 
- Komurka, V.E., Wagner, A.B. and Edil, T.B, 2003. Estimating soil/pile setup. USA WHRP Report No 03-05, Wisconsin Department of Transportation.

- Konard, J. M. and Roy, M., 1987. Bearing capacity of friction piles in marine clay. Geotechnique, Vol. 37, No. 2, pp 163-175.

- Kraft, L. M., Focht, J. A., and Amerasinghe, S. F., 1981. Friction capacity of piles driven into clay. Journal of the Geotechnical Engineering Division, ASCE, Vol. 107, No. GT11, pp 1521-1541.

- Ladanyi, B., 1963. Expansion of a cavity is saturated medium. JSMFD, ASCE, Vol. 89, SM4, pp 127-161.

- Laefer, D.F., 2001. Prediction and assessment of ground movement and building damage induced by adjacent excavation, PhD Thesis UIUC. pp. 903.

- Lambe, T. W., and Horn, H. M., 1965. The influence on an adjacent building of pile Driving for the M.I.T. materials center. Proceedings, 6th ICSMFE, Montreal, Vol. II, pp 280-284.

- Lehane,B. M. and White D. J., 2005. Lateral stress changes and shaft friction for model displacement piles in sand. Canadian Geotechnical Journal, 42, 10151029. 
- Leifer, S.A., Kirby, R.C. and Esrig, M.I., 1979. Effect of radial variation in modulus on stress after consolidation around a driven pile. Proc. of the Conference on Numerical Methods in Offshore Piling, London, England, pp. 15763.

- Lemos, L., 1986. The effect of rate of shear on the residual strength of soil. PhD Thesis, Imperial College, University of London.

- Lemos, L., and Vaughan, P.R., 2000. Clay-Interface shear resistance. Géotechnique 50, No.1, pp.55-64.

- Leung, C. F., Radhakrishnan, R., and Tan, S., 1991. Performance of precast driven piles in marine clay. Journal of Geotechnical Engineering, ASCE, Vol. 117, No. 4, pp 637-657.

- Lo, K. Y., and Stermac, A. G., 1965. Induced pore pressures during pile driving operations. Proc. 6th ICSMFE, Vol. 2, 285.

- Long J.H., Kerrigan J.A., and Wysockey M.H., 1999, Measured time effects for axial capacity of driven piling. Journal of the Transportation Research Board, No. 1663, Paper No. 99-1183.

- Lukas, R.G., and Bushell, T.D., 1989. Contribution of soil freeze to pile capacity. Foundation Engineering: Current Principles and Practices, Vol. 2, ASCE, pp 9911001. 
- Lupini, J.F., Skinner, A.E., and Vaughan, P.R., 1981. The drained residual strength of the cohesive soils. Geotechnique, 31(2), pp. 181-213.

- Matlock, H., and Bogard, J. D., 1973. Lateral load behavior of piles and pile groups under surcharge. Report to Chevron Oil Filed Research Company, Austin, Texas.

- Mayne, P. W., 1988. Determining OCR in clay from laboratory strength. ASCE Journal of Geotechnical Engineering, Vol. 114, No. 1, Jan, 1988, pp. 76-92

- McCammon, N. R., and Golder, H. Q., 1970. Some loading tests on long pipe piles. Geotechnique, Vol. 20, No. 2, pp 171-184.

- McClleland Engineers, 1969. Additional soil investigation. Pile Research Program, block 100, Eugene Island Area. Report to Shell Oil Company.

- McClleland, B., 1972. Design and performance of deep foundations in clay. General Report ASCE Specialty Conf. Performance of Earth and Earth Supported Structures, 2, pp 111-114.

- McManis, K. L., Folse, M. D., and Elias, J. S., 1988. Determining pile bearing capacity by some means other than the engineering news formula. Research Report No. 234, LTRC, Baton Rouge, LA.

- McVay, M. C., Schmertmann, J., Townsend, F., and Bullock, P., 1999. Pile friction freeze: A field and laboratory study. Research Report No. WPI 0510632 , Florida Department of Transportation, Tallahassee, Fla. 
- Mesri G., Feng T.W. and Benak J.M., 1990. Post-densification penetration resistance of clean sands. Journal Geotech. Engng., ASCE, Vol. 116(7), pp 10951115.

- Meyerhof, G. G., 1976. Bearing capacity and settlement of pile foundations. Journal of Geotechnical Engineering Division, ASCE, Vol. 102, No. 3, pp 197228.

- Mitchell, J. K., 1960. Fundamental aspects of thixotropy in soils. JSMFD, ASCE, Vol. 86, No. SM3, pp 19-52.

- Mitchell, J. K., 1993. Fundamentals of soil behavior. John Wiley and Sons, New York, $437 \mathrm{pp}$

- Nishida, Y., 1964. A basic calculation on the failure zone and the initial pore pressure around a driven pile. Proc. of the First Reg. Asian Conf. On Soil Mech. and Found. Eng., Tokyo, 1, pp 217-219.

- O'Rourke, T.D., Druschel, S.J. and Netravali, A.N., 1990. Shear strength characteristics of sand polymer interfaces. J. of Geotechnical Engineering, ASCE, Vol. 116, No. 3, pp. 451-469.

- O'Neill, M. W., 1983. Group action in offshore piles. Proc. Of the Conference on Geotechnical Practice in Offshore Engineering, ASCE, Univ. of Texas at Austin, pp. 25-64, April 27-29, 1983. 
- Orrje, O., and Broms, B., 1967. Effects of pile driving on soil properties. Journal of the Soil Mechanics and Foundation Division, ASCE, Vol. 93, No. SM5, pp 5973.

- Paikowsky, S.G., LaBelle, V. A., and Mynampaty, R.N., 1995. Static and dynamic time dependent pile behavior. Research Report submitted to the Mass. Highway Department, Geotechnical Section, Boston, Ma.

- Parry, R. H. G., and Swain, C. W., 1977. Effective stress method of calculating skin friction on driven piles in soft clay. Ground Engineering 10, No. 3, pp 24-26.

- Peck, R. B., 1958. A study of the comparative behavior of friction piles. Special Report 36, Highway Research Board.

- Pestana, Juan M., Hunt, Christopher E., and Bray, Jonathan D., 2002. Soil deformation and excess pore pressure field around a closed end pile. Journal of Geotechnical and Geoenvironmental Engineering, Volume 128, No. 1, ASCE, pp.1-12.

- Potyondy J. G., 1961. Skin friction between various soils and construction materials. Geotechnique, 11(4):831-8

- Poulos, H. G., and Davis, E. H., 1980. Pile foundation analysis and design. John Wiley and Sons Inc. 
- Preim, M.J., March, R., and Hussein, M., 1989. Bearing capacity of piles in soils with time dependent characteristics. Piling and Deep Foundations, Volume 1, pp. $363-370$.

- Randolph, M. F., and Wroth, C. P., 1979. An analytical solution for the consolidation around a driven pile. International Journal for Numerical and Analytical Methods in Geomechanics, Vol. 3, pp 217-229.

- Randolph, M. F., Carter, J. P., and Wroth, C. P., 1979. Driven piles in clay-the Effects of installation and subsequent consolidation. Geotechnique, Vol. 29, No. 4, pp 361-393.

- Randolph, M.F., Carter, J.P., and Wroth, C.P., 1979. Driven piles in clay - the erect of installation and subsequent consolidation. Geotechnique, 29(4): 301-327.

- Rouaiguia, A., 2010. Residual shear strength of clay-structure interfaces. International Journal of Civil \& Environmental Engineering IJCEE-IJENS, Vol. 10 No: 03.

- Roy, M., Blanchet, R., Tavenas, F. and La Rochelle, P., 1981. Behavior of sensitive clay during pile driving. Canadian Geotechnical Journal, Vol. 18, pp 6785.

- Schmertmann, J.H., 1991. The mechanical ageing of soils. Journal of Geotechnical Engineering, ASCE, 117(9): 1288-1330. 
- Seed, H. B., and Reese, L. C., 1955. The action of soft clay along friction piles. Proceedings, ASCE, Vol. 81, Paper No. 842.

- Skempton A. W., and Northey, R. D., 1952. The sensitivity of clays. Geotechnique, Vol. III, No. 1, pp 30-51.

- Skov, R. and Denver, H., 1988. Time-dependence of bearing capacity of piles., Proc. of $3^{\text {rd }}$ Inter. Conf. on the Application of Stress-Wave Theory to Piles, Ottawa, 25-27 May: 879-888.

- Skove, R, and Denver, H., 1988. Time-Dependence of bearing capacity of piles. Third International Conference on Applications of Stress Wave Theory to Piles, ISSMFE and Canadian Geotechnical Society, Ottawa, Canada.

- Soderberg, L. O., 1962. Consolidation theory applied to foundation pile time effects. Geotechnique, Vol. 12, No. 3, pp 217-225.

- Sutton, V. J., and Rigden, B. P., 1979. A full scale instrumented pile test in the North Sea. Offshore Technology Conference, Houston, Texas, Paper No. 3489.

- Svinkin, M. R. Morgano, C. M., and Morvant, M., 1994. Pile capacity as a function of time on clayey and Sandy soils. Proc. Of the $5^{\text {th }}$ International conference on Piling and Deep foundations, Deep Foundations Institute, Englewood Cliffs, N.J., 1.11.1-1.11.8. 
- Svinkin, M.R., and Skov, R., 2000. setup effect of cohesive soils in pile capacity. Proc. of Int. Conf. of Application of Stress Waves to Piles, Sao Paulo, Brazil, Balkema, pp. 107-111.

- Sweeney, D. A., Wong, D. K. H. and Fredlund, D. G., 1988. Effect of lime on highly plastic clay with special emphasis on ageing. Transportation Research Record 1190, Washington, pp 13-23.

- Taha, A. M., 2010. Interface shear behaviour of sensitive clays- Leda clay. ProQuest Dissertation \& Theses (PQDT)

- Teh, C. I., and Houlsby, G. T., 1987. Discussion for “ undrained deep penetration I: Shear Stresses" by Baligh, M. M.. Geotechnique, Vol. 37, No. 4, pp 523-527. I

- Terzaghi, K., 1941. Undisturbed clay samples and undisturbed clays. Journal of the Boston Society of Civil Engineers, Vol. 28, No. 3, pp 211-231.

- Terzaghi, K., 1943. Theoretical soil mechanics, John Wiley and sons, New York.

- Thorburn, S., and Rigden, W. J., 1980. A practical study of pile behavior. Proceedings, Offshore Technology Conference, Paper 3825, Houston, Texas, USA.

- Titi, H. H., 1996. The increase in shaft capacity with time for friction piles driven into saturated clay. ProQuest Dissertation \& Theses (PQDT)

- Tomlinson, M. J., 1971. Adhesion of piles driven in clay soils. Proc. $4^{\text {th }}$ Int. Conf. of Soil Mechanics and Foundation Engineering, London, 12, pp 86-71. 
- Tomlinson, M.J., 1994. Pile design and construction practice. Chapman and Hall Publisher, London.

- Torrance, J., 1975. On the role of chemistry in the development and behaviour of the sensitive marine clays of Canada and Scandinavia. Canadian Geotechnical Journal, 12, 326-335.

- Tsubakihara Y. and Kishida H., 1993. Frictional behavior between normally consolidated clay and steel by two direct shear type apparatus. Soils and Foundations, 33(2): 1-13.

- Tumay, M.T., Acer, Y.B., and Chan, S.K.A., 1982. Analysis of dissipation of pore pressure after Cone Penetration. Interim Research Report No. 3 for State Project No. 736-04-55, submitted to the Louisiana Department of Transportation and Development.

- Uesugi M. and Kishida H., 1986. Frictional resistance at yield between dry sand and mild steel. Soils and Foundations, 26(4):139-149.

- Van den Berg, P., 1994. Analysis of soil penetration. Delft University Press, The Netherlands, 1994.

- Vesic, A. S., 1972. Expansion of cavities in infinite soil mass. International Journal of Soil Mechanics and Foundation Division, ASCE, 98, pp. 265-290. 
- Vesic, A. S., 1977. Design of pile foundation. National Cooperative Highway Research Program, Synthesis of Highway Practice No. 42, Transportation Research Board, National Research Council, Washington, D.C., USA.

- Wathugala, G. W., and Desai, C. S., 1993. Constitutive model for cyclic behavior of clays. I: Theory. Journal of Geotechnical Engineering, ASCE, Vol. 119, No. GT4, pp 714-729.

- Woodward, R. J., Lundgren, R., and Boitano, J., 1961. Pile loading tests in stiff clays. Proc. $5^{\text {th }}$ Int. Conf. of Soil Mechanics and Foundation Engineering, Vol. 2, pp 177-184.

- Wroth, C. P., Carter, J. P., and Randolph, M. F., 1979. Stress changes around a pile driven into cohesive soil; Recent developments in the design and construction of piles. Institution of Civil Engineers, London, pp 345-3U.

- Yang, N., 1956. Redriving characteristics of piles. Journal of Soil Mechanics and Foundation Division, ASCE, Vol. 82, SM3, Paper 1026.

- Zeevaert, L., 1959. Reduction of point bearing capacity of piles because of negative friction. Proc. of the Pan-American Conference on Soil Mechanics and Foundation Engineering, Mexico, 3, pp 1145-1152.

- Zelikson, A., 1969. Geotechnical models using the hydraulic gradient similarity method. Geotechnique. 19(4) 495-508. 


\section{APPENDIX A}

Numerical analysis report

On soil sample container 


\section{Load/Deformation}

Report generated using GeoStudio 2007, version 7.17. Copyright 0 1991-2010 GEO-SLOPE International Ltd.

\section{File Information}

Revision Number: 45

Date: $13 / 09 / 2012$

Time: 4:58:01 PM

File Name: Pile_Compression_test - 003.gsz

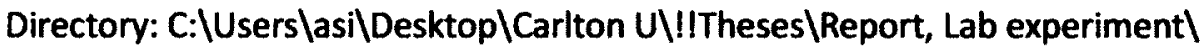

\section{Project Settings}

Length(L) Units: meters

Time(t) Units: Seconds

Force(F) Units: $k N$

Pressure(p) Units: $\mathrm{kPa}$

Strength Units: $\mathrm{kPa}$

Stiffness Units: $\mathrm{kPa}$

Unit Weight of Water: $9.807 \mathrm{kN} / \mathrm{m}^{3}$

Air Pressure: $101.33 \mathrm{kPa}$

View: 2D

\section{Analysis Settings}

\section{Load/Deformation}

Kind: SIGMA/W

Parent: Insitu

Method: Load/Deformation

Settings

Initial Stress: Parent Analysis

Initial PWP: Water Table

Exclude cumulative values: No

Control

Apply Body Force in All Steps: No

Use Constant Stress: Yes

Adjust Fill: No

Convergence 
Maximum Number of Iterations: 50

Displacement Norm Tolerance: $0.5 \%$

Equation Solver: Direct

Time

Starting Time: 0 sec

Duration: $1 \mathrm{sec}$

\# of Steps: 1

Save Steps Every: 1

Use Adaptive Time Stepping: No

\section{Materials}

\section{Leda Clay}

Model: Linear Elastic

Stress Strain

Young's Modulus (E): $65000 \mathrm{kPa}$

Unit Weight: $20 \mathrm{kN} / \mathrm{m}^{3}$

Poisson's Ratio: 0.49

\section{Boundary Conditions}

\section{Fixed X/Y}

$X: X$-Displacement 0

Y: Y-Displacement 0

\section{Pull out}

$X: 0$

Y: Y-Force 0.3

\section{Structural Beams}

\section{Pile-Concrete}

E-Modulus: $30000000 \mathrm{kPa}$

Area: $0.0019635 \mathrm{~m}^{2}$

Inertia: $3.048 \mathrm{e}-007 \mathrm{~m}^{\wedge} 4$

Allow Tension: Yes

Allow Compression: Yes

\section{Initial Water Tables}




\section{Initial Water Table 1}

Max. negative head: $\mathbf{5}$

Coordinates

Coordinate: $(0,0.9) \mathrm{m}$

Coordinate: $(0.7,0.9) \mathrm{m}$

\section{Regions}

\begin{tabular}{|c|c|c|c|}
\hline & Material & Points & Area $\left(\mathrm{m}^{2}\right)$ \\
\hline Region 1 & Leda Clay & $3,9,5,6,10,4,2,1$ & 0.52601007 \\
\hline
\end{tabular}

Lines

\begin{tabular}{|l|c|c|l|}
\hline & Start Point & End Point & \multicolumn{1}{|c|}{ Beam } \\
\hline Line 1 & 5 & 6 & Pile-Concrete \\
\hline Line 2 & 8 & 9 & Pile-Concrete \\
\hline Line 3 & 9 & 5 & Pile-Concrete \\
\hline Line 4 & 3 & 9 & \\
\hline Line 5 & 6 & 10 & Pile-Concrete \\
\hline Line 6 & 10 & 7 & Pile-Concrete \\
\hline Line 7 & 4 & 10 & \\
\hline Line 8 & 7 & 11 & Pile-Concrete \\
\hline Line 9 & 11 & 8 & Pile-Concrete \\
\hline Line 10 & 4 & 2 & \\
\hline Line 11 & 2 & 1 & \\
\hline Line 12 & 1 & 3 & \\
\hline
\end{tabular}

\section{Points}




\begin{tabular}{|l|r|r|c|}
\hline & $X(\mathrm{~m})$ & $Y(\mathrm{~m})$ & Stress/Strain Boundary \\
\hline Point 1 & \multicolumn{1}{|c|}{0} & \multicolumn{1}{c|}{0} & Fixed X/Y \\
\hline Point 2 & \multicolumn{1}{c|}{0.6} & \multicolumn{1}{c|}{0} & Fixed X/Y \\
\hline Point 3 & 0 & 0.9 & Fixed X/Y \\
\hline Point 4 & 0.6 & 0.9 & Fixed X/Y \\
\hline Point 5 & 0.29 & 0.2 & \\
\hline Point 6 & 0.31 & 0.2 & \\
\hline Point 7 & 0.31 & 0.99 & \\
\hline Point 8 & 0.29 & 0.99 & \\
\hline Point 9 & 0.29 & 0.9 & \\
\hline Point 10 & 0.31 & 0.9 & \\
\hline Point 11 & 0.3 & 0.99 & Pull out \\
\hline
\end{tabular}




\section{APPENDIX B}

\section{PIEZOMETER SPECIFICATION}




\section{Vibrating Wire Piezometers}

\section{DESCRIPTION

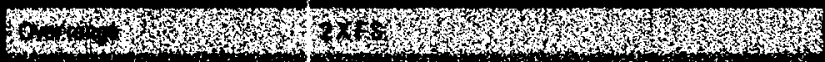

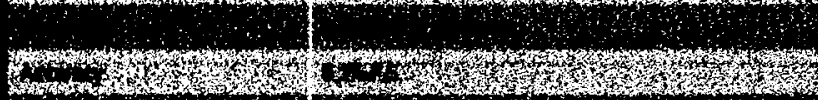

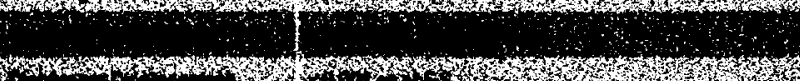

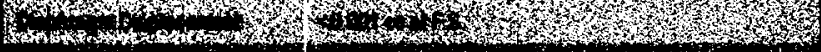

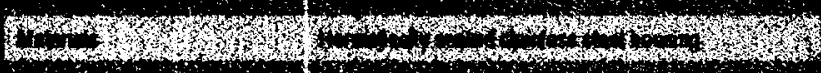

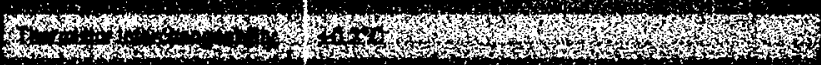

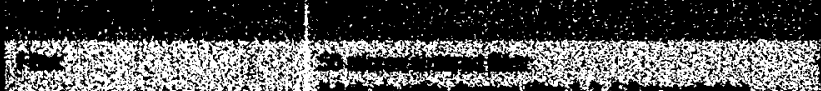

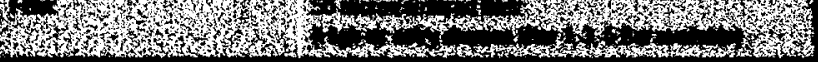

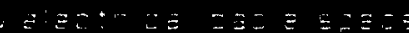

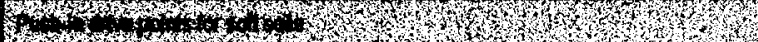
W.

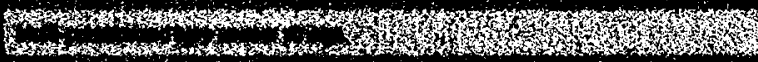

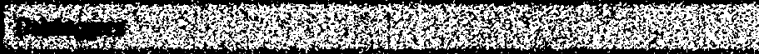

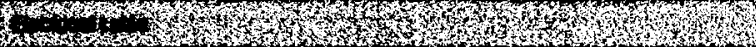
W

PART \# OESCRIPTION W.

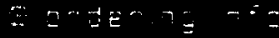

PRESSURE RANGE

DHAENSION

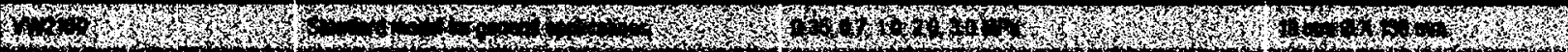

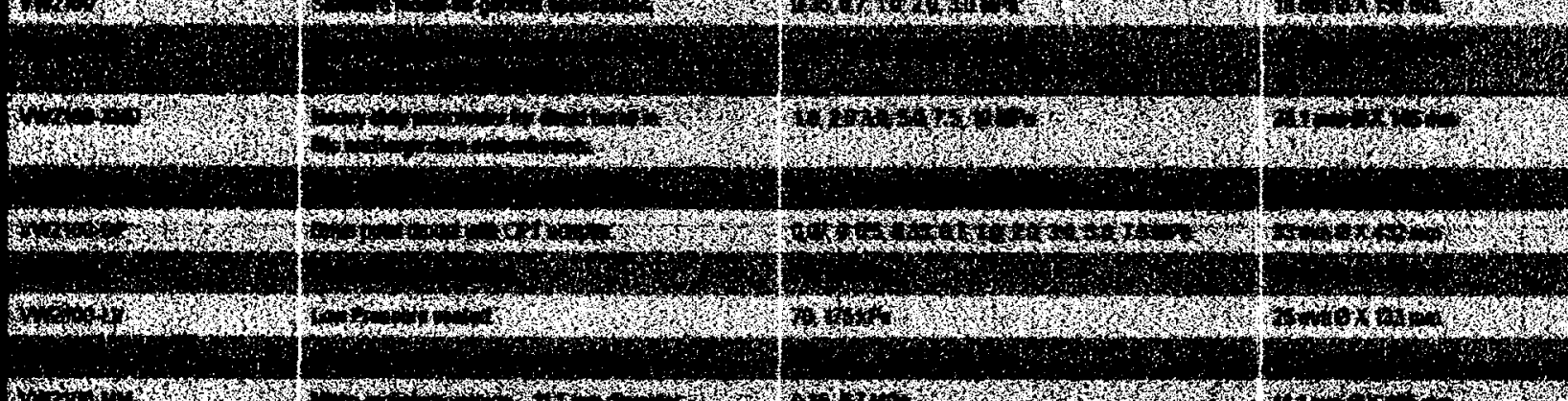

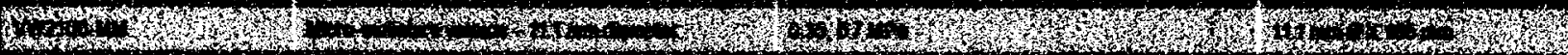




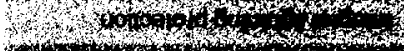
㪍

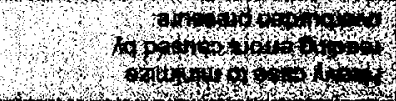
ons

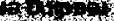

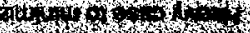

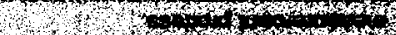

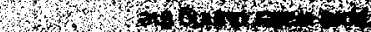

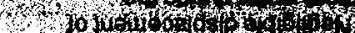

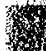

4twis

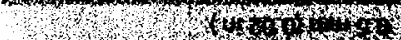

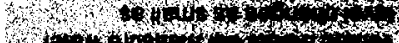

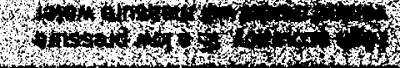

to

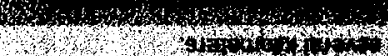
$1000(1,1)+4$

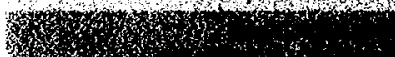

W

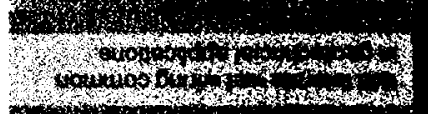

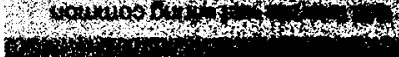

$5 \Xi+7 ;=3 ; \%$

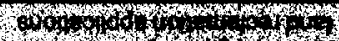

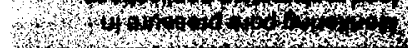

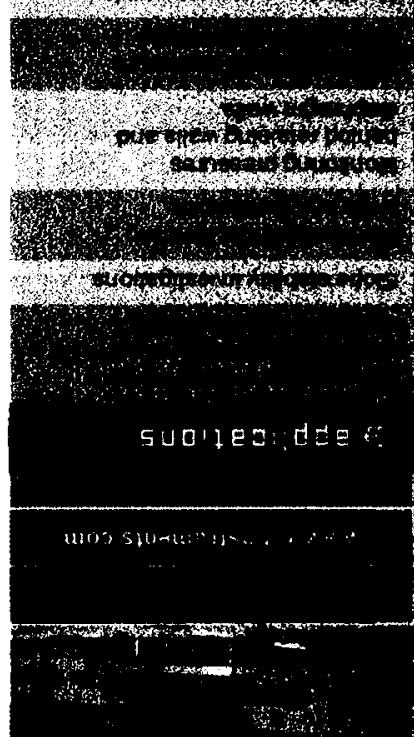

1317

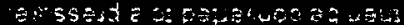

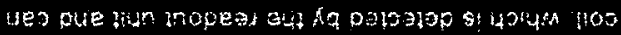

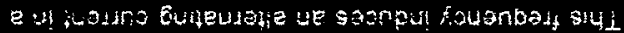

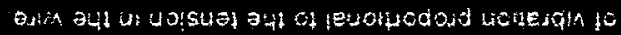

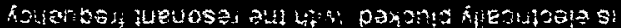

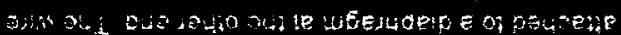

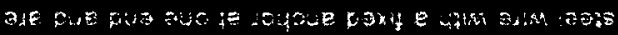

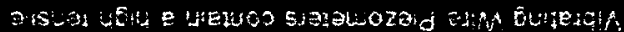

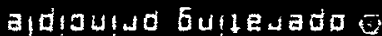

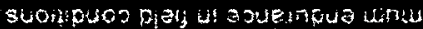

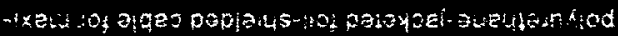
E.

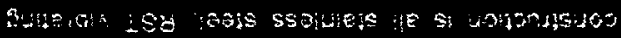

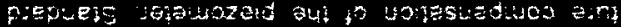

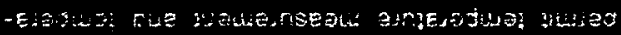

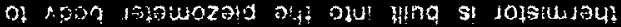

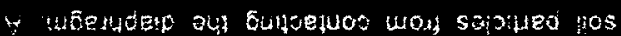

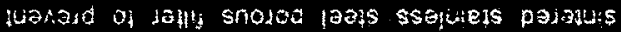

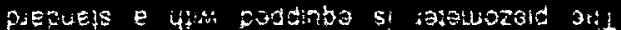

WS De;Entes

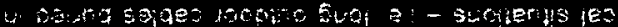

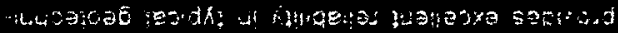

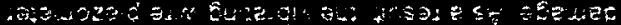

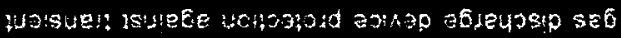

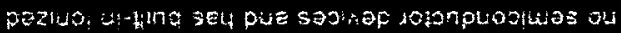

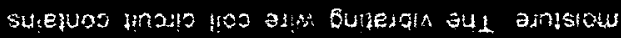

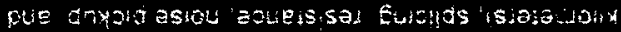

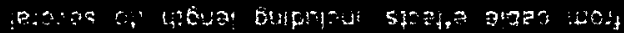

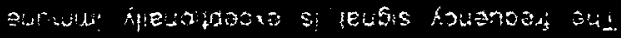

3irssetion a:

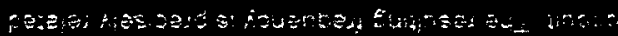

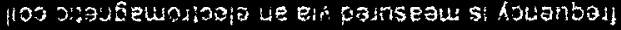
yeuasol aul uall pue ozeran of panpu si zim

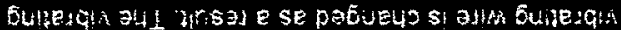

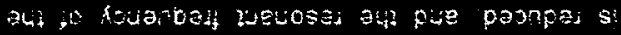

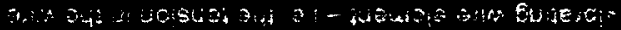

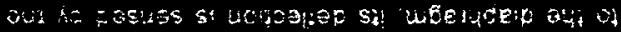

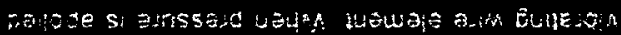
E

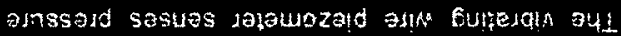

Suoneshdae lestuinatoab

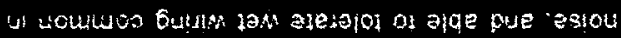

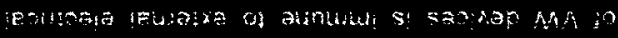

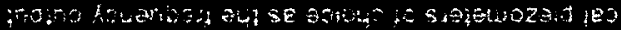
4.1

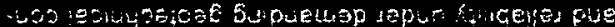

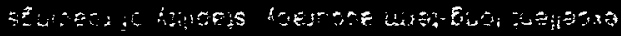

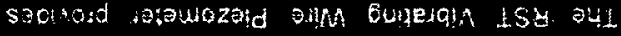

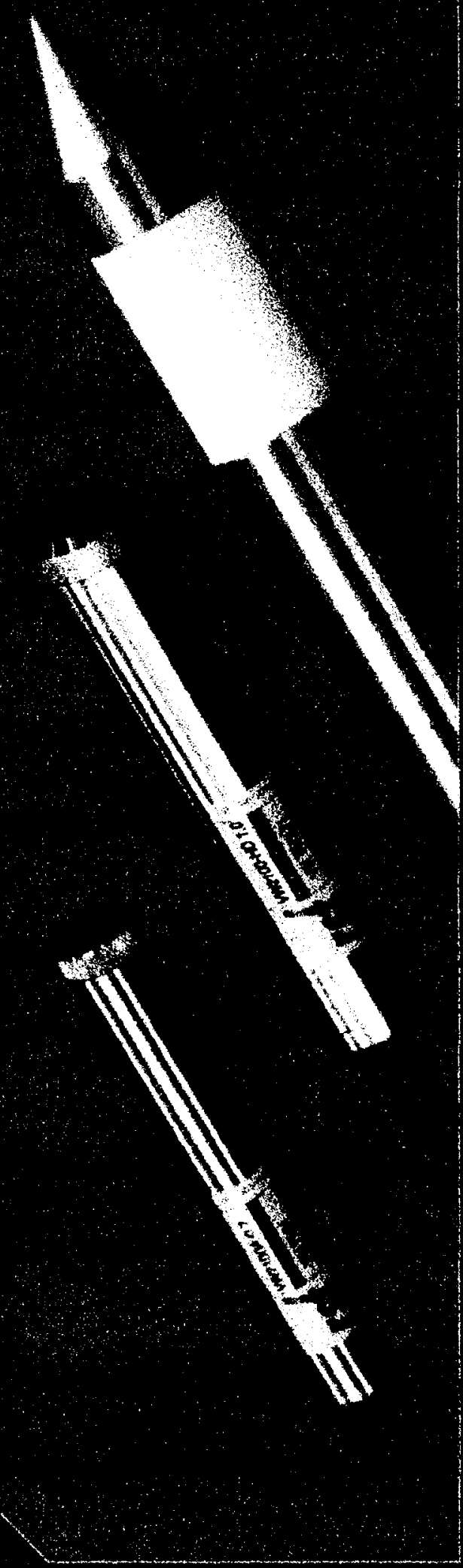

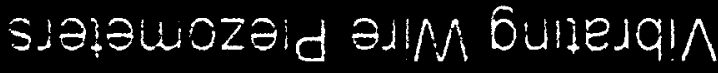

